University of Michigan Law School

University of Michigan Law School Scholarship Repository

Articles

Faculty Scholarship

2003

\title{
Agency Burrowing: Entrenching Policies and Personnel before a New President Arrives
}

Nina A. Mendelson

University of Michigan Law School, nmendel@umich.edu

Available at: https://repository.law.umich.edu/articles/212

Follow this and additional works at: https://repository.law.umich.edu/articles

Part of the Administrative Law Commons, Law and Politics Commons, and the President/ Executive Department Commons

\section{Recommended Citation}

Mendelson, Nina A. "Agency Burrowing: Entrenching Policies and Personnel before a New President Arrives." N. Y. U. L. Rev. 78, no. 2 (2003): 557-666.

This Article is brought to you for free and open access by the Faculty Scholarship at University of Michigan Law School Scholarship Repository. It has been accepted for inclusion in Articles by an authorized administrator of University of Michigan Law School Scholarship Repository. For more information, please contact mlaw.repository@umich.edu. 


\title{
AGENCY BURROWING: ENTRENCHING POLICIES AND PERSONNEL BEFORE A NEW PRESIDENT ARRIVES
}

\author{
NinA A. Mendelson*
}

\begin{abstract}
This Article examines executive branch agency actions concluded just before a new President takes office, such as "midnight" rulemaking and late-term hiring and promotion, which Professor Mendelson collectively refers to as "agency burrowing." Congress, the media, and some commentators have portrayed such activities as unsavory power grabs that undermine the President-elect's ability to direct the functions of administrative agencies. Rather than dismissing agency burrowing out of hand, however, Professor Mendelson argues for a more nuanced approach. In some cases, burrowing can make positive contributions to the democratic responsiveness of agencies, agency accountability, and the "rule of law." A fuller analysis of burrowing also suggests the need for a more nuanced approach to Presidentcentered theories of the administrative state. Maximum presidential oversight may be insufficient to ensure agency accountability and democratic responsiveness. Instead of focusing centrally on a formal President-agency relationship, we may wish to give greater attention to more functional means of ensuring agency legitimacy such as monitoring, focused public dialogue on issues before agencies, and agency development of self-limiting rules.
\end{abstract}

Copyright (C) 2003 by Nina A. Mendelson. As of May 2004, this work will be licensed under the Creative Commons Attribution-NoDerivs-NonCommercial License. To view a copy of this license, visit http://creativecommons.org/licenses/by-nd-nc/1.0/ or send a letter to Creative Commons, 559 Nathan Abbott Way, Stanford, California 94305, USA.

* Assistant Professor, University of Michigan Law School. J.D., 1989, Yale Law School. I am very grateful to a number of former and current federal agency officials who allowed me to interview them anonymously for this Article and whom I have occasionally quoted. They include political appointees, including some confirmed by the Senate, and career civil servants that have served in senior policymaking positions. Collectively, the interviewees have worked under both Republican and Democratic Presidents and in several federal agencies, including the Executive Office of the President, the Environmental Protection Agency (EPA), and the Departments of Housing and Urban Development, Interior, Justice, and Treasury.

I am also greatly indebted to Steven Croley, Becky Eisenberg, Daniel Halberstam, Don Herzog, Robert Howse, Kyle Logue, Jeff Lehman, Deborah Malamud, Jerry Mashaw, Riyaz Kanji, Sallyanne Payton, Richard Primus, Terry Sandalow, and Peter Westen for valuable comments and discussion, and to Matt Andelman. Joshua Doan, Peter Nemerovski, Christian Richeson, and Gregg Severson for cheerful and thorough research assistance. I also appreciate the generous research support of the University of Michigan Law School's Cook Fund.

This Article is dedicated with admiration to John C. Cruden, Esq., Deputy Assistant Attorney General for Environment and Natural Resources, a civil servant truly committed to the public interest and a talented and inspiring manager. Although John was not one of those I spoke with about this project, it was his chance comment that started me thinking about the issue. 
I. The Burrowing Phenomenon................... 559

II. The President and Executive Branch Agencies....................................... 569

A. Concerns About Agency Discretion ............. 569

B. Agencies, Legitimacy, and the President.......... 577

1. Conceptions of Democracy in the Agency Context ................................ 578

2. The Administrative State as the Agent of an Elected President........................... 579

3. Agency-Centered Conceptions of Legitimacy in the Administrative State .................... 585

III. A Normative Assessment of Agency Burrowing ............................. 588

A. Policy Burrowing and Its Costs ............... 589

1. Characteristic Policy Entrenchment Actions ..... 589

2. The Costs of Policy Entrenchment ............ 599

B. Personnel Burrowing and Its Costs............. 606

1. Characteristic Personnel Entrenchment Actions.. 606

2. The Costs of Personnel Entrenchment......... 610

C. Salutary Effects of Burrowing................. 616

1. Contributions to the Legitimacy of Agency Decisionmaking ......................... 616

a. Policy Burrowing as a Creator of Public Dialogue: The Roadless Areas Rule as a Case Study ......................... 619

b. Creation of a Public Policy Dialogue and Information "Benchmarks" ............. 628

c. Personnel Burrowing's Benefits for Internal Agency Deliberation................... 641

2. Contributions to Agency Accountability ........ 647

a. Improved Monitoring .................. 648

b. Greater Policy Transparency and Stability Through Creation of Administrative Limiting Rules..................... 652

3. Policy Entrenchment Other Than Rulemaking .. 657

IV. Some Concluding Observations on Burrowing ... 660

A. Evaluating Policy and Personnel Burrowing........ 660

B. Revising the Focus on Presidential Control ......... 663 


\section{The Burrowing Phenomenon}

1952, President Harry Truman: "He'll sit right here . . and he'll say do this, do that!! And nothing will happen. Poor Ike-it won't be a bit like the Army."1

December 2000, Question from White House Press ConferENCE: "Do you think [President Clinton's] decision to switch the [presidential limousine] license plates [to the new District of Columbia 'Taxation without Representation' plates] should be seen as one in a series of actions the President is taking to try to tie the hands of [President Bush, given his lack of support for D.C. statehood]?" (Laughter.)

Answer from White House Press Secretary Jake Siewert: "This is a decision that's made on the President's own views about D.C. and its statehood. But, obviously, we're not tying the hands of anyone. Screwdrivers are a dime a dozen." 2

January 20, 2001, Washington Post: "Even before he was sworn in, George W. Bush went out of his way to show that reports of his disdain for this city were right true. Yesterday, he said that the Taxation Without Representation license plates... [on] the presidential limousine would be removed, pronto."3

Towards the end of every presidential administration, bureaucrats joke about "burrowing" into the government and "leaving alligator eggs." They are referring to actions taken just before the President ends her term of office. Since there is no impending election, the President may feel relatively unhampered. ${ }^{4}$

1 Margaret Truman, Harry S. Truman 551-52 (1973) (internal quotations omitted).

2 Office of the Press Secretary: Press Briefing by Jake Siewert, M2 Presswire, Dec. 27, 2000, LEXIS, Nexis Library, M2 Presswire File.

3 Marc Fisher, Inaugural Events Washed Over by Feelings of Unease, Wash. Post, Jan. 20,2001 , at B1.

4 See, e.g., Keith Schneider, Environment Gets a Flurry of Final Acts, N.Y. Times, Jan. 16,1993 , at Al ("Leaders of environmental, industrial and property rights groups ... noted that the election results had freed Mr. Bush and his deputies from any lingering political ramifications caused by the decisions."); see also Jack M. Beermann, Presidential Power in Transition 21 (Boston Univ. Sch. of Law, Working Paper Series, Public Law \& Legal Theory Working Paper No. 02-20, 2002), http://ssrn.com/abstract=349560 (noting that transition-period actions could be characterized either as democratic insult or as President rising above narrow interests). Implicitly-or explicitly-these actions declare that until January 20, the President is still the President, with all the accompanying prerogatives of the office, including the authority and responsibility to set policy. See, e.g., William S. Morrow, Jr., Midnight Regulations: Natural Order or Disorderly Governance, Admin. \& Reg. L. News, Spring 2001, at 3, 18 ("[T]he nation expects its chief executive to continue working up until the last day, just as Congress does." (paraphrasing Sally Katzen, former Office of Management and Budget (OMB) Acting Deputy Director under President Clinton)); George 
Presidents have often acted dramatically just before departing. President John Adams, of course, used his appointments authority to issue the judicial commissions at issue in Marbury v. Madison. ${ }^{5}$ Other outgoing Presidents, such as Theodore Roosevelt-who issued an executive order creating what is now the Olympic National Park in Washington State "just hours before he left office" - have preserved many millions of acres of public lands. Departing President Hoover created several national monuments, including Death Valley, California and White Sands, New Mexico. ${ }^{7}$ President Carter signed one of the most far-reaching federal statutory liability provisions ever enacted in the Comprehensive Environmental Response, Compensation, and Liability Act in December, 1980, a month before the end of his term. ${ }^{8}$ And President Clinton issued scores of last-minute presidential pardons. ${ }^{9}$

Although they might seem prosaic by comparison with set-asides of public lands and presidential pardons, executive branch agencies also make numerous policy and personnel decisions just before a new President arrives, and these decisions almost certainly have a greater overall impact.

By the term "agency burrowing," I refer to executive branch agency activities ${ }^{10}$ that are legal and, despite the connotation of underground tunneling, rarely explicitly secretive in nature. Instead, the

Lardner, Jr., Farewell Burst of Rules, Grants Alarms GOP; Strict Transitional Etiquette Proving Difficult to Maintain, Wash. Post, Dec. 30, 1980, at A2 ("President Carter, of course, has said that he intends to 'be the president in the fullest sense of the word until Inauguration Day,' which is Jan. 20.").

5 See Jonathan T. Molot, The Judicial Perspective in the Administrative State: Reconciling Modern Doctrines of Deference with the Judiciary's Structural Role, 53 Stan. L. Rev. 1, 58-59 (2000) (describing those who attack these last-minute appointees as "political hacks"); William W. Van Alstyne, A Critical Guide to Marbury v. Madison, 1969 Duke L.J. 1, 6 (discussing timing of appointments).

6 John D. Leshy, Shaping the Modern West: The Role of the Executive Branch, 72 U. Colo. L. Rev. 287, 302 (2001).

7 Id. at 292.

8 Comprehensive Environmental Response, Compensation, and Liability Act of 1980, Pub. L. No. 96-510, 94 Stat. 2767 (codified as amended at 42 U.S.C. $\$ \$ 9601-9675$ (2000)) (imposing retroactive, strict, and joint and several liability for cleanup costs, subject only to limited defenses, upon wide array of parties with connection to hazardous waste disposal).

${ }^{9}$ Marc Lacey, Clinton Pardons Deutch but Not Milken or Hubbell, N.Y. Times, Jan. 21, 2001, at A1 (noting Clinton's issuance of 140 pardons "[w]ith just hours to go in his presidency").

11 "Burrowing in," in bureaucratic jargon, refers to a prohibited action by a "political" agency employee, normally terminable at will, see 5 U.S.C. $\$ 7511$ (2000) (stating "for cause" removal provisions do not apply to range of appointments as determined by President), to convert her position into one with tenure under the civil service rules, terminable only for cause. See $\$ 7513$ (providing "for cause" removal for civil service employees); Qualifications Review Board Certification, 5 C.F.R. $\$ 317.502$ (2002) (stating prohibition on conversion). 
activities might be conceived of as the administration resisting change or digging in its heels. An agency may select a particular policy, viewpoint, or person, make the choices relatively durable, and do so in anticipation of a presidential transition.

Thus, an executive branch agency might decide a policy question and entrench it through the issuance of a legislative rule, a proposed rule, or other public statement of agency position or policy. For example, a legislative rule, if properly issued, has the "force of law" with respect to both the agency and to private parties. ${ }^{11}$ Modification or abandonment of such a rule can be costly, time-consuming, and troublesome for a new administration. ${ }^{12}$ After Election Day, 2000, Clinton administration executive branch agencies finalized numerous rules that, among other things, substantially reduced the permitted level of arsenic in drinking water (Environmental Protection Agency (EPA)), ${ }^{13}$ required employers to make their workplaces more ergonomically sensitive (Occupational Safety and Health Administration (OSHA)) ${ }^{14}$ imposed patient privacy requirements on health care providers (Department of Health and Human Services), ${ }^{15}$ and reserved nearly sixty million acres of forest-approximately one-third of all national forest land-designating it off-limits to timber harvesting and road-building (Forest Service). ${ }^{16}$

This volume of policy decisions in the last several weeks before a presidential transition was not unique to the Clinton presidency. ${ }^{17}$ As

11 Batterton v. Francis, 432 U.S. 416, 425 n.9 (1977) (declaring that properly issued substantive agency regulations must be given force of law by court).

12 See infra text accompanying notes 152-61. See generally David E. Rosenbaum, Bush Rules! It's Good to Be the President, N.Y. Times, Jan. 28, 2001, $\$ 4$ (Week in Review), at 16 (noting that "Clinton administration worked overtime to lock in place a range of rules the Republicans find objectionable" and that approved regulations "can be changed only through tedious bureaucratic procedures").

13 See National Primary Drinking Water Regulations; Arsenic and Clarifications to Compliance and New Source Contaminants Monitoring, 66 Fed. Reg. 6976 (Jan. 22, 2001) (to be codified at 40 C.F.R. pts. 9, 141, 142).

14 See Ergonomics Program, 65 Fed. Reg. 68,262, 68,262 (Nov. 14, 2000) (to be codified at 29 C.F.R. pt. 1910).

15 See Standards for Privacy of Individually Identifiable Health Information, 65 Fed. Reg. 82,462 (Dec. 28, 2000) (to be codified at 45 C.F.R. pts. 160, 164).

16 See Special Areas; Roadless Area Conservation, 66 Fed. Reg. 3244, 3245 (Jan. 12, 2001) (to be codified at 36 C.F.R. pt. 294). The United States Forest Service also issued new national forest planning rules intended to place the ecological health of forests first, ahead of timbering, mining, and many other potential uses of national forests. See National Forest System Land Resource Management Planning, 65 Fed. Reg. 67,514 (Nov. 9, 2000) (to be codified at 36 C.F.R. pts. 217, 219).

17 See Hearing on Implementation of Environmental Laws Before Senate Comm. on Gov't Affairs, 107th Cong. (2002) (testimony of Thomas O. McGarity, Professor of Law, University of Texas) [hereinafter Testimony of McGarity] (noting volume of proposed and final regulations increased during last few weeks of Clinton administration and "same thing 
one of the final acts of President George H.W. Bush's administration, the Department of the Interior finalized a critical and controversial set of regulations on assessing the value of contaminated natural resources and delivered them to the Office of the Federal Register the afternoon of January 19, 1993, the eve of President Clinton's inauguration. ${ }^{18}$ That was one of approximately one hundred "eleventh-hour" Bush administration actions. ${ }^{19}$ Similarly, on January 19, 1981, the Secretary of Health and Human Services under President Carter approved a final rule creating a "bill of rights" for residents in nursing homes receiving Medicare and Medicaid payments. ${ }^{20}$ The approval was issued despite significant concern about the rule's costs ${ }^{21}$ and notwithstanding the knowledge that the incoming administration was likely to be uncomfortable with the rule. ${ }^{22}$ Following one count, the

happened at the end of the Carter and George H.W. Bush Administrations"), http://govtaff.Senate.gov/030702mcgarity.htm.

18 See Kennecott Utah Copper Corp. v. U.S. Dep't of the Interior, 88 F.3d 1191, 120001 (D.C. Cir. 1996). Under the Clinton administration, however, the Interior Department requested that the rule be withdrawn from the Federal Register. It made that request on January 21, 1993. Id. The Court of Appeals for the D.C. Circuit agreed with the Clinton administration that the agency possessed statutory authority to withdraw the rule from the Office of the Federal Register prior to publication. Id. at 1206.

19 See, e.g., Ronald Begley, Bush EPA Goes Out in a Blaze of Regulations, Chemical Wk., Jan. 27, 1993, at 9 (describing rules and proposals as reflective of corporate desires); Clinton Plans to Revoke Bush's 11th-Hour Actions, Orlando Sentinel Trib., Jan. 25, 1993, LEXIS, News Group File (reporting that Clinton administration planned to rescind "about 100" last-minute Bush administration measures); Schneider, supra note 4 (discussing variety of "striking decisions affecting national parks, forests, agriculture, land, industrial wastes and endangered species").

20 On January 21, 1981, under the newly arrived Reagan administration, the Department of Health and Human Services (HHS) approval of the regulation was withdrawn, as there had been some question regarding the Secretary's authority to approve the regulation. See Withdrawal of Secretarial Approval, Conditions of Participation for Skilled Nursing and Intermediate Care Facilities, 46 Fed. Reg. 7408 (Jan. 23, 1981) (to be codified at 42 C.F.R. pts. 405, 442, 483) (announcing withdrawal of January 19 Secretarial approval of nursing-facilities rules). A congressional appropriations rider prohibited publication of the proposed rule pending a General Accounting Office (GAO) report on financial issues, a report that had not yet been transmitted in final form to HHS. See Pub. L. No. 96-536, $\$ 119,94$ Stat. 3166, 3172 (1980) (rider); Timothy B. Clark, Outgoing Carterites Rush to the Printer with a Flood of Rules, Nat'l J., Jan. 24, 1981, at 127 (reporting HHS Secretary Harris's awareness of contents of GAO report and GAO's failure to transmit it formally).

21 See, e.g., Spencer Rich, U.S. Details Rights in Nursing Homes, Wash. Post, July 10 , 1980 , at A2 (observing that HHS estimated implementation costs of about eighty million dollars per year while National Council of Health Centers said cost would be "closer to $\$ 1$ billion").

22 See Lardner, supra note 4 (remarking that memo of incoming Republicans to White House Chief of Staff "dealt fretfully with the projected costs of some nursing home regulations that were said to be in the works at the Department of Health and Human Services"). 
nursing home rule was one of 172 " 'midnight' regulations" issued by the outgoing Carter administration. ${ }^{23}$

According to a recent study, regulatory activity, measured by Federal Register pages as a very rough proxy, has surged in the last quarter of the presidential term in every presidency since at least $1948 .{ }^{24}$ Reportedly, the turnover of a whole administration is, on average, associated with a twenty-nine percent jump in this measure of regulatory activity during the postelection period. ${ }^{25}$ Taking into account how much the "pace of regulation at the end surged above that during the rest of his tenure, the record-holder is the first President George Bush."26

Similarly, an agency may engage in significant personnel entrenchment. So-called "political appointees," whose jobs within an executive branch agency typically would be terminated with the departure of the President, can be moved to a civil service position with tenure in the same agency. While a relatively small number of individuals make these sorts of moves, those that do tend to have held-and to continue to hold-positions with substantial policymaking responsibility. 27 Outgoing political appointees also may hire significant num-

${ }^{23}$ Dick Kirschten, President Reagan After Two Years-Bold Actions but Uncertain Results, Nat'l J., Jan. 1, 1983, at 4, 10; see also infra note 355 (summarizing Reagan response to Carter regulations).

24 See generally Jay Cochran, III, The Cinderella Constraint: Why Regulations Increase Significantly During Post-Election Quarters (Mar. 8, 2001) (unpublished manuscript, on file with the New York University Law Review) (testing anecdotal impression that volume of regulations increases significantly during postelection quarters of election years). Federal Register pages are far from a perfect measure of regulatory activity since those pages can include not only new rule notices but a variety of other notices, such as rule repeals, public meetings, or proposed litigation settlements. Moreover, agency regulations obviously range widely in terms of their economic and social impact, not to mention page length. See id. at 2 n.4.

25 Hearing on the Congressional Review Act Before the House Subcomm. on Energy Policy, Natural Res., and Regulatory Affairs of Comm. on Gov't Reform, 107th Cong. (2001) (statement of Dr. Wendy L. Gramm).

26 Amy Goldstein, 'Last-Minute' Spin on Regulatory Rite: Bush Review of Clinton Initiatives Is Bid to Reshape Rules, Wash. Post, June 9, 2001, at A1.

27 In the last two years of the Clinton administration, one hundred political appointees moved to civil service positions. U.S. Gen. Accounting Office, GAO/GGD-02-326, Report to Congressional Requesters: Personnel Practices: Career and Other Appointments of Former Political Appointees, October 1998-April 2001, at 2 (2002) [hereinafter GAO, 1998-2001 Personnel Practices]. In the administration of President George H.W. Bush, approximately 160 individuals made such career moves. See U.S. Gen. Accounting Office, GAO/GGD-96-2, Report to the Honorable Patricia Schroeder, House of Representatives: Personnel Practices: Career Appointments of Legislative, White House, and Political Appointees, at 5 (1995) [hereinafter GAO, 1995 Personnel Practices] (finding that in last two years of Bush administration, 159 individuals moved from noncareer positions to career positions); see also id. (reporting that 110 individuals moved from noncareer positions to career civil service positions in last two years of Reagan administration). 
bers of civil servants or promote individuals to key supervisory positions inside the agency, sometimes with an eye to ensuring that the outgoing administration's viewpoints and priorities remain represented within the agency. ${ }^{28}$

Something about this activity strikes us as unseemly. Our discomfort surely does not arise from the fact that the government has continued to function postelection. Few would wish the executive branch to simply cease operations between Election Day and January 20 of the following year. Further, some transition period is necessary between election and inauguration in the event of uncertain electoral results or to permit the new President to prepare to govern and to assemble her Cabinet. ${ }^{29}$ Moreover, as long as she is in office, of course, the President has the constitutional obligation to "take Care that the Laws be faithfully executed." 30

Rather, the concern is that the outgoing administration not only has continued to govern despite its impending departure and the electoral loss but also is apparently governing more vigorously. Of course, many of these actions may be motivated by the desire simply to complete projects before Inauguration Day or to deliver on promises publicly made. ${ }^{31}$ Or, as others have argued, forces beyond the agency's control may delay completion of actions. ${ }^{32}$ Finally, the activities might be utterly routine.

Some of these actions, however, present particular problems. Whether or not an outgoing President or administrator could be said to have "rushed" an action, the difficult questions on which I seek to focus arise from the set of significant policy decisions seemingly made in the face of a strong suspicion or even clear information that the President-elect would prefer a different choice. Even when a policy question has been "in the works" for some time, the agency's choice in the last few weeks to proceed regardless of the new President's views suggests an unsatisfied craving for power.

Actions taken without regard for the new President's preferences also could generate a broader cynicism about those in power. Notwithstanding their participation in a recent presidential election, vot-

\footnotetext{
28 See infra text accompanying notes 209-24.

${ }^{29}$ See Sanford Levinson, Presidential Elections and Constitutional Stupidities, 12 Const. Comment. 183, 185-86 (1995) (noting possible need for time when no candidate gets electoral majority); Richard E. Neustadt, Presidential Transitions: Are the Risks Rising?, 1 Miller Center J. 3, 4-8 (1994) (discussing dangers of presidential "newness" and "haste").

30 U.S. Const. art. II, $\$ 3$.

31 See infra text accompanying notes 174-75.

32 E.g., Beermann, supra note 4, at 17-18.
} 
ers may perceive that it is business as usual inside the government. ${ }^{33}$ Perhaps agencies are making policy not to serve the public will but in spite of it. ${ }^{34}$ At worst, these decisions might strike some as nosethumbing by the outgoing administration at the public's choice of a new President, especially when the new President is of a different political party. That in turn could threaten the expressive and constitutive value to the voter of participating in the presidential election. ${ }^{35}$

Members of Congress regularly have expressed their concern about such agency burrowing. In President Clinton's case, congressional Republicans accused him of inappropriately trying to tie the hands of President George W. Bush by "cramming through scores of

33 See Morrow, supra note 4, at 3 (quoting Senior Federal Circuit Judge S. Jay Plager as telling citizens that policy entrenchment "makes control of the regulatory apparatus appear to be a Washington game"); see also B. Dan Wood \& Richard W. Waterman, Bureaucratic Dynamics: The Role of Bureaucracy in a Democracy 10 (1994) ("Most citizens believe that bureaucracies are large, rigid, self-interested entities moving slowly along a predetermined path.").

34 One might argue that burrowing presents us with no meaningful democratic difficulties but simply a timing problem. Since every electing constituency gets to choose a President that will have an opportunity to "burrow" after the next election, perhaps voters should be satisfied as long as those opportunities are the same for each electing constituency. Further, even if power shifted almost immediately after an election or burrowing were to be limited for some period of time, perhaps there still would be anticipatory preelection entrenchment, which we could not consider antidemocratic. On this view, burrowing presents merely the question whether voters get the benefit of having their chosen leaders in office from November to November or January to January.

However, characterizing the issue this way is unsatisfying. First, it implies that nearly any prize flowing from an electoral victory would raise no issue of democratic legitimacy as long as every electing majority got the same prize. This cannot be correct, however. For example, the electorate would likely view as dubious a two-year delay before their electorally chosen leaders took office, even if the same conditions applied to every other electing majority. The time allowed for American transitions is already comparatively long. See Nancy Amory Combs, Carter, Reagan, and Khomeini: Presidential Transitions and International Law, 52 Hastings L.J. 303, 329 (2001) (observing that governmental transitions in other countries after elections are generally shorter than in United States). In short, the position fails to attach significant expressive value to an infrequent, concerted electoral action.

Second, characterizing the burrowing problem as purely a trivial one of timing does not take account of the fact that the costs of entrenchment to the outgoing administration vary with time. Entrenchment is likely to be less appealing before an election than it is afterward. For example, to the extent policy entrenchment reduces agency flexibility, its costs, such as loss of policymaking flexibility and greater liability exposure, will be higher the earlier it is done. See infra text accompanying notes 151-61. Moreover, to the extent personnel entrenchment or reorganization is an attempt to subvert or dismantle a program, the costs of such activity also likely will be higher in the preelection period. See Beermann, supra note 4 , at 17 (identifying desire to avoid political consequences or other effects of action as reason to "wait" until lame duck period to act).

35 Cf. Ellen D. Katz, Race and the Right to Vote After Rice v. Cayetano, 99 Mich. L. Rev. 491, 512-13 (2000) (examining intrinsic values of voting). 
rules and other regulatory decisions." 36 Congressional Republicans made similar complaints about President Carter. ${ }^{37}$ Before President George H.W. Bush left office, congressional Democrats likewise mounted a vigorous defense of President Clinton's prerogatives. ${ }^{38}$ Commentators, too, have expressed concern about these practices. In Sandy Levinson's words, "there is something profoundly troubling, to a democrat, in allowing repudiated Presidents to continue to exercise the prerogatives of what is usually called the 'most powerful political office in the world." "39 One commentator recently has suggested that Congress prohibit altogether the promulgation of final regulations during the transition period. ${ }^{40}$

Administrative agency burrowing strikes us as antidemocratic at least in part because it seems aimed at undermining the control and authority of the newly elected President. ${ }^{41}$ Moreover, these actions often are postelection so that voters potentially lose an important tool

36 James Inhofe, News Column of Senator Inhofe: Last Minute Regulatory Rush, Oct. 15, 2000, at http://inhofe.senate.gov/preleases.htm; see Kenneth J. Cooper \& Sarah Schafer, At the Company, Change Is in the Wind: Workers Have Lived Through Gust or Two, Wash. Post, Nov. 9, 2000, at A27 (reporting that Occupational Safety and Health Administration (OSHA) was "working round the clock on the final version of its controversial ergonomics rule" despite fact that Republican-led Congress was "bitterly opposed"); see also A Rush to Regulate-The Congressional Review Act and Recent Federal Regulations: Hearing Before the House Subcomm. on Energy Policy, Natural Resources and Regulatory Affairs of Comm. on Gov't Reform, 107th Cong. 4 (2001) [hereinafter A Rush to Regulate] (statement of Congressman Doug Ose) (asserting that some late-term Clinton rules raise "serious concerns").

37 See, e.g., Helen Dewar, Congress Funds Government, Adjourns, Wash. Post, Dec. 17,1980 , at A1 (describing adjournment-delaying fight "led by angry Republican conservatives who had tried to use [appropriations legislation] to block the Carter administration from leaving behind a mass of new regulations covering everything from scenic-river designations to tax exemption for private schools").

38 See infra notes 212-15 (citing sources on congressional concern about late-term Bush personnel and organizational decisions); see also Stephen Barr, The Fast Track from Appointee to Career Status, Wash. Post, Dec. 18, 1992, at A29 (mentioning GAO examination of " 25 federal agencies in which there are more than 50 allegations of political appointees attempting to improperly obtain civil service positions").

39 Levinson, supra note 29 , at 184-85; see id. at 185 (noting "mischief that can be done by a tired, perhaps bitter, repudiated incumbent"); see John Copeland Nagle, A Twentieth Amendment Parable, 72 N.Y.U. L. Rev. 470, 484-86 (1997) (summarizing case against lame duck Congresses); cf. Cass R. Sunstein, Changing Conceptions of Administration, 1987 BYU L. Rev. 927, 938 (stating that President's function of "energiz[ing] and direct[ing]" regulatory policy is especially important at beginning of presidential term).

40 See Morrow, supra note 4, at 18 ("[Senior Federal Circuit Judge Plager] suggested a more effective measure would be to have Congress pass a law prohibiting submission of final regulations during the interregnum."); see also Beermann, supra note 4, at 65-79 (exploring variety of potential reforms to limit "midnight regulations" or facilitate later administrations' reversing them).

41 See also supra note 34 (discussing argument that postelection power is not antidemocratic as long as every winning coalition obtains it). 
for holding agencies accountable. As a theoretical matter, these concerns gain strength because some recent academic commentary relies heavily upon the President as a major source of democratic responsiveness and accountability for the modern, enormously powerful administrative state. ${ }^{42}$ Even commentators who do not see presidential control as central see it as a significant feature of a legitimate administrative state. ${ }^{43}$ Scholars have suggested that because the President is an elected official, she can be relied upon to respond to public preferences and to transmit them to the executive branch agencies. If agency burrowing seems antidemocratic and holding agencies accountable for such actions seems more difficult, perhaps there is a presumptive case against agency burrowing, and we should find it illegitimate.

I want to suggest, however, that the issue is not so simple. We should not, without a fuller assessment, dismiss agency burrowing out of hand. I will not try to press an overall case either for or against burrowing. If anything, a fuller assessment reveals that burrowing's effects seem to vary with the type of agency activity and the factual circumstances. Agency burrowing has some real costs, especially political and efficiency costs for the President-elect. However, commentators who identify the President as a source of legitimacy for administrative agencies implicitly assume that the public's values and policy preferences generally are determinate, well-informed, and communicated through the electoral process. This often is not the case for the complex and detailed policy questions faced by executive branch agencies.

Consequently, some agency burrowing can make salutary contributions to the democratic responsiveness of agency policymaking, whether by helping assure that agency deliberations take account of a greater variety of viewpoints or by triggering a new and more focused public debate on a particular policy question that in turn can inform the ultimate agency decision. Burrowing also can increase agency accountability to the public and to monitoring institutions. The presence of these consequences underscores the need to think beyond an overly simple view of burrowing and to emphasize a variety of sources of legitimacy and accountability for the administrative state.

Part II of this Article briefly overviews the current context of substantial executive branch agency discretion and then turns to recent commentary that has sought to justify agency activities as democratically legitimate and accountable. Some of that commentary relies

\footnotetext{
42 See infra text accompanying notes 104-14.
}

43 See infra text accompanying notes 115-31. 
centrally on the President as the source of legitimacy for the administrative state; most commentary relies on the President to play a significant role. Part III examines burrowing practices in detail, focusing particularly on late-term rulemaking and personnel burrowing, and discusses the costs they impose on the President-elect. While acknowledging that these costs can be significant, especially in the case of personnel burrowing, Part III maintains that agency burrowing, under some circumstances, can make significant contributions both to the democratic responsiveness and accountability of agencies. Part III's assessment draws from an examination of the Clinton administration's "roadless areas" rule as well as other examples of policy entrenchment.

Part III argues that because presidential support for a particular policy should not be taken to imply the existence of ex ante public support, an outgoing administration's effort to entrench policy through rulemaking can generate a valuable, more focused public policy dialogue which in turn can better inform the new President's decisionmaking on critical issues. Similarly, entrenchment of personnel by an outgoing administration is likely to help ensure increased political diversity among agency employees, thereby increasing the range of views considered in agency deliberation. Moreover, an outgoing administration's desire to entrench its policy decisions may lead it to constrain its own discretion more actively, and entrenched personnel may serve as internal monitors of agency activity, reducing the prospect of abuse and capture. Both these types of actions may increase agency accountability.

Part IV identifies key features of burrowing that might render a particular activity more or less legitimate. It then discusses the implications of agency burrowing activity for President-centered theories of agency legitimacy and contends that an exclusive theoretical focus on the President would be overly narrow. For example, other features of the administrative state may contribute to its democratic responsiveness, such as agency actions that are responsive to a national debate on a policy issue. Similarly, an agency's decisions to use more transparent procedures and to impose legal limits upon its own discretion are likely to increase agency accountability independent of whether the agency is closely supervised by the President. Part IV concludes by urging the need to focus more functionally on achieving democratic responsiveness and accountability in the administrative state. 
II

\section{The President and Executive Branch Agencies}

Suppose we view late-term agency burrowing as a departing President's last clutch at power, with the effect, and perhaps also the intention, of undermining the new President's effectiveness. Our instinct may be to see these efforts as thereby undermining the democratic credentials of the administrative state. This Part looks in more detail at the foundation for such a response.

Agencies possess considerable authority that seems only weakly controlled by Congress, agency self-regulation, and under some circumstances, the courts. The relative lack of control by other branches would seem to make the President's role more important as a source of legitimacy for the administrative state. In fact, current theoretical accounts of legitimacy in the administrative state, which cover a range of perspectives, nearly universally rely on the President's relationship with the agencies as either a direct source of democratic responsiveness or a check against undemocratic agency decisionmaking. This theoretical reliance on the President gives additional force to the concerns about burrowing's impact on a President-elect.

This Part very briefly overviews agency discretion and the extent it can be seen as constrained by institutions other than the President. It then turns to examining theoretical approaches to legitimacy in the administrative state and their reliance, either centrally or significantly, upon the President.

\section{A. Concerns About Agency Discretion}

A civic-minded individual obviously could be concerned that agency burrowing would undermine presidential control over agencies. Such concerns seem more troubling in view of the already sizeable discretion that agencies possess. Since the New Deal, agencies have received congressional delegations to make countless key policy decisions balancing competing values such as efficiency, equity, health, and cost. ${ }^{44}$ Congress may delegate such broad authority because it believes it lacks the expertise to develop policies, because it

44 See, e.g., Antonin Scalia, Judicial Deference to Administrative Interpretations of Law, Administrative Law Lecture (Jan. 24, 1989), in 1989 Duke L.J. 511, 516 ("Broad delegation to the Executive is the hallmark of the modern administrative state."); Mark Seidenfeld, Bending the Rules: Flexible Regulation and Constraints on Agency Discretion, 51 Admin. L. Rev. 429, 443 (1999) ("Congress tends to write statutory prescriptions to cover broad rather than particular regulatory contexts. ... In addition, statutory standards derive from a political process that downplays the importance of technical knowledge ...."). 
cannot reach a consensus, ${ }^{45}$ or because it may prefer to take credit for solving a social problem while abdicating responsibility for imposing the costs required by the solution. ${ }^{46}$

Although congressional oversight of administrative agency performance and implementation of statutory mandates can be quite effective when it is used, the prospects for in-depth and systematic oversight are limited. Congress can veto particular agency actions but does so rarely, ${ }^{47}$ in part because such legislation faces substantial institutional and political obstacles. ${ }^{48}$ Congressional oversight efforts also tend to be fragmented and reactive to particular agency proposals as

45 See, e.g., Victoria F. Nourse \& Jane S. Schacter, The Politics of Legislative Drafting: A Congressional Case Study, 77 N.Y.U. L. Rev. 575, 595-96 (2002) (noting that pressure to pass legislation successfully can result in conscious decision not to answer policy question or to leave answer ambiguous).

46 See Theodore J. Lowi, The End of Liberalism: Ideology, Policy, and the Crisis of Public Authority 155 (1969) (suggesting Congress may be unable to reach consensus); Peter H. Aranson et al., A Theory of Legislative Delegation, 68 Cornell L. Rev. 1, 21-26 (1983) (describing managerial and political concerns driving delegation); Lisa Schultz Bressman, Schechter Poultry at the Millennium: A Delegation Doctrine for the Administrative State, 109 Yale L.J. 1399, 1406 (2000) (positing that Congress may wish to delegate for "purpose of avoiding responsibility for hard choices"); Jerry L. Mashaw, Prodelegation: Why Administrators Should Make Political Decisions, 1 J.L. Econ. \& Org. 81, 85 (1985) (stating that Congress may try to claim credit with one constituency while "avoiding potentially energetic opposition" from another constituency or, because of its inability to agree on any single course of action, may "pass a vague statue [which] in effect creates a public policy lottery"); Mark Seidenfeld, A Big Picture Approach to Presidential Influence on Agency Policy-Making, 80 Iowa L. Rev. 1, 8-9 (1994) (finding that Congress forced to grant considerable discretion in part due to "size and complexity of the government's regulatory role"). Mashaw argues that Congress's tendency to duck difficult policy questions does not necessarily entail adverse social welfare consequences, because delegating these questions to a more politically insulated institution may be preferable. I do not compare congressional decisionmaking with administrative decisionmaking directly, but instead take as a given that Congress is unlikely to take on the detailed, hard questions of its own accord and that it is unlikely to be compelled by another institution to do so. See infra text accompanying notes $52-53,75$.

47 See, e.g., Thomas O. McGarity, Some Thoughts on "Deossifying" the Rulemaking Process, 41 Duke L.J. 1385, 1450 (1992) (observing sporadic nature of substantive congressional review of agency rules).

48 See Mashaw, supra note 46, at 96 ("The high transactions costs of legislating specifically suggests that legislative activity directed to the modification of administration mandates will be infrequent."); Mark Seidenfeld, A Civic Republican Justification for the Bureaucratic State, 105 Harv. L. Rev. 1511, 1551 (1992) ("Because overrides entail significant transaction costs, they occur infrequently."); Seidenfeld, supra note 44, at 482 ("Legislative inertia and the gatekeeping function of congressional committees can prevent Congress from responding even when there is a general consensus on the need for legislative action."). Even the Congressional Review Act, enacted in 1995 to create a relatively streamlined process to reverse administrative action, has been used only once. See infra sources cited in note 135 (recounting use of Act to repeal ergonomics rule). 
opposed to providing a coherent overall approach to monitoring agency performance. ${ }^{49}$

If it were present, close congressional control could make agencies more accountable and increase the chance that significant policy decisions would be made by elected officials, implicitly more democratically responsive. ${ }^{50}$ A number of commentators have argued for such close congressional control. ${ }^{51}$ However, the nondelegation doctrine is unlikely to be revived any time soon; meanwhile broad congressional delegations of authority are favored.52 Moreover, the

${ }^{49}$ See Seidenfeld, supra note 46 , at 10-11 (discussing difficulties with ex post congressional oversight of agency performance). Individual members of Congress may be motivated to seek oversight opportunities that likely will gain them greater political credit, more votes, or campaign contributions. In the words of Bernard Rosen,

Unless [the oversight activity] reveals a scandalous situation, the work is . . . considered dull, with the potential to be troublesome politically. . . For elected officials the incentives favor looking ahead, not back. Response to current concerns of individual constituents and work on legislation desired by influential groups have more direct bearing on future elections-and political survival is paramount for many.

Bernard Rosen, Holding Government Bureaucracies Accountable 87 (3d ed. 1998). See generally Matthew D. McCubbins \& Thomas Schwartz, Congressional Oversight Overlooked: Police Patrols Versus Fire Alarms, 28 Am. J. Pol. Sci. 165 (1984) (describing two contrasting models of congressional oversight).

50 See Jerry L. Mashaw, Greed, Chaos, and Governance: Using Public Choice to Improve Public Law 131 (1997) ("Legislative specification of agency jurisdiction, purposes, and powers thus provides the normative justification for administrative authority and implies an instrumental conception of administration-agencies are created and empowered in order to implement policy choices made in the legislative process."). Of course, democratic responsiveness may not be sufficient to satisfy the public, who also may seek technically adequate agency decisions.

51 See, e.g., Gary Lawson, The Rise and Rise of the Administrative State, 107 Harv. L. Rev. 1231, 1231 (1994) ("The post-New Deal administrative state is unconstitutional ...."); David Schoenbrod, Remarks to the Board of Trustees of the Natural Resources Defense Council (Mar. 12, 1997), in 20 Cardozo L. Rev. 767, 772 (1999) ("Congress should stop delegating lawmaking power to EPA.").

52 See, e.g., Whitman v. Am. Trucking Ass'ns, 531 U.S. 457 (2001) (upholding delegation to EPA to set air quality standards at level "requisite to protect the public health"). In Whitman, the Court stated tellingly, and unanimously, that it has " almost never felt qualified to second-guess Congress regarding the permissible degree of policy judgment that can be left to those executing or applying the law." Id. at 474 (quoting Mistretta v. United States, 488 U.S. 361, 416 (1989) (Scalia, J., dissenting)). Since 1935, the Supreme Court has rejected every constitutional challenge to congressional delegations of lawmaking authority to agencies. See, e.g., NBC v. United States, 319 U.S. 190, 225-26 (1943) (sustaining authority to regulate in "public interest"); see also Mashaw, supra note 46, at 82 ("Statutory delegations of authority of wondrous breadth evade the nondelegation doctrine's supposed strictures."). But see Lawson, supra note 51, at 1237 (arguing that broad delegations are unconstitutional). See generally Bressman, supra note 46 (arguing that Chevron review of agency interpretations can fulfill nondelegation doctrine-like function).

However, some have argued that Congress's recent delegations have been more precise and that Congress has imposed more procedural requirements. See, e.g., Elena Kagan, Presidential Administration, 114 Harv. L. Rev. 2245 (2001) (discussing more detailed delegations); Seidenfeld, supra note 44, at 443 ("Political dissatisfaction with agency 
prospects for congressional oversight of agency activity ex post, such as through appropriations limitations or the use of the subpoena power, are inherently limited by time and resource constraints. ${ }^{53}$

Meanwhile, a great many agency actions also escape procedural discipline. Although the Administrative Procedure Act (APA) ${ }^{54}$ does require a so-called "notice-and-comment" procedure for informal rulemaking and a quasi-judicial adversary hearing for formal adjudication (and the rarely used formal rulemaking), 55 agencies very often possess-and exercise-the legal discretion to avoid using these procedures. ${ }^{56}$ The APA imposes no procedural requirements whatsoever on the remaining catch-all category of agency actions, so-called "informal adjudication," which ranges from agency actions distributing government-grant funds to actions setting fires in national forests to decisions not to accept asylum applications (such as the highly visible one filed by the Cuban six-year old Elian Gonzales ${ }^{57}$ ).

Judicial discipline of agencies is rarely extensive. ${ }^{58}$ Even absent detailed procedural or substantive requirements, courts can impose some discipline upon agencies in reviewing final agency actions as "arbitrary" or "capricious" under the Administrative Procedure Act. ${ }^{59}$ Judges can "ensure that the agency thought hard about its decision, reasoned logically, and stayed within the permissive bounds of discretion set by [a] statute."60 However, the periodic attempts of lower courts to demand greater agency rationality or restraint, such as "ad-

performance has, of late, led Congress to provide very detailed statutory prescriptions for regulatory problems."); see also McCubbins \& Schwartz, supra note 49, at 167-68 (averring that Congress may rationally decide to pursue methods of oversight other than "police patrol").

53 See supra note 48 and accompanying text.

54 Administrative Procedure Act, ch. 324, 60 Stat. 237 (1946) (codified as amended in scattered sections of 5 U.S.C.).

55 See 5 U.S.C. $\$ 553(2000)$ (listing requirements for informal rulemaking); $\$ \$ 554,556$ (listing requirements for formal adjudication and rulemaking).

56 Statutory provisions that authorize agencies to issue binding rules generally are permissive rather than mandatory. See infra text accompanying note 62 . Further, agencies typically have preferred to avoid the trial-type procedures of formal adjudication as a means of setting policy. See, e.g., Stephen G. Breyer et al., Administrative Law and Regulatory Policy 677 (5th ed. 2002) (noting increasing agency use of rulemaking in preference to formal adjudication); Mashaw, supra note 50, at 158-59 (observing shift from adjudication to rulemaking); Todd D. Rakoff, The Choice Between Formal and Informal Modes of Administrative Regulation, 52 Admin. L. Rev. 159, 163 (2000) (highlighting "shift [in] the emphasis of the system from adjudicating cases to promulgating rules").

57 See generally Gonzalez v. Reno, 212 F.3d 1338 (11th Cir. 2000).

58 See, e.g., Mashaw, supra note 50, at 113-14 (describing increasingly deferential approach taken in judicial review of administrative decisions).

59 See 5 U.S.C. $\$ 706(2)(A)$.

60 Seidenfeld, supra note 46 , at 9 . 
versary probing" of obviously doubtful conclusions, largely have been halted by the Supreme Court. ${ }^{61}$

Similarly, while an agency may restrain itself by issuing legally binding procedures or substantive decision criteria in the form of legislative rules, Congress usually leaves to agency discretion the decision of whether to implement such rules-or, if Congress requires some rules, how confining the rules will be. ${ }^{62}$ If used, these "administrative limiting standards," in Lisa Bressman's words, can constrain agency action meaningfully, as they are legally binding and their development generally is subject to procedural requirements. ${ }^{63}$ For example, the Forest Service has from time to time used rulemaking to detail the criteria that individual employees must use in developing forest management plans for the national forests. ${ }^{64}$

However, agencies generally do not have a strong incentive to self-regulate through binding, transparently developed rules. Because of the desire to preserve flexibility and discretion or to reduce regula-

61 See, e.g., Vt. Yankee Nuclear Power Corp. v. Natural Res. Def. Council, 435 U.S. 519,524 (1978) (reversing D.C. Circuit attempt to demand "adversary probing" and ruling that Administrative Procedure Act (APA) established "maximum procedural requirements which Congress was willing to have the courts impose upon agencies in conducting rulemaking procedures"). For a more recent example, see Whitman v. Am. Trucking Ass'ns, 531 U.S. 457, 472-76 (2001) (reversing D.C. Circuit attempts to use nondelegation doctrine to compel agencies to explain principles underlying regulatory decisions). Moreover, the Court has upheld agency flexibility to make policy either through rulemaking or through the more flexible (though more procedurally demanding) device of formal adjudication. E.g., NLRB v. Bell Aerospace Co., 416 U.S. 267, 295 (1974) (upholding agency discretion). See generally Seidenfeld, supra note 44 , at $441 \&$ n. 40 . But see Corrosion Proof Fittings v. EPA, 947 F.2d 1201, 1213-14 (5th Cir. 1991) (closely scrutinizing agency action); Bressman, supra note 46, at 1399-1400 (focusing on judicial invalidation of agency interpretations for failure to contain "limiting standard").

62 Even when Congress enacts mandatory rulemaking requirements, it very often leaves the scope of the rules up to the agency. See, e.g., 7 U.S.C.A. $\$ 1638$ c(b) (West Supp. 2002) (requiring Agriculture Department to issue country-of-origin food labeling regulations by 2004 , but only "as are necessary to implement this subchapter"); see also 7 U.S.C. $\S 2015(d)(4)(J)(2000)$ (establishing nonspecific mandatory rulemaking requirement in food stamps program); 7 U.S.C.A. $\$ 2025$ (c)(1)(F)(iv) (West Supp. 2002); 42 U.S.C. $\S 9605(a)$, (a)(3) (2000) (compelling EPA to issue regulations governing, inter alia, selection of response actions for contaminated waste sites, but instructing agency only to develop "criteria for determining the appropriate extent of removal, remedy, and other measures authorized by this chapter").

63 See Bressman, supra note 46 , at 1401 . For the proposition that such rules are legally binding upon the agency, see Ariz. Grocery Co. v. Atchison, Topeka \& Santa Fe Ry. Co., 284 U.S. 370 (1932) (declaring that agency must follow its own rules). But see United States v. Caceres, 440 U.S. 741 (1979) (holding that criminal defendant could not exclude evidence obtained by IRS in violation of its own regulations). Moreover, when such standards are issued as legislative rules, agencies generally must follow APA notice-and-comment rulemaking procedures. See 5 U.S.C. $\$ 553$.

64 E.g., National Forest System Land Resource Management Planning, 65 Fed. Reg. 67,514, 67,514-81 (Nov. 9, 2000) (to be codified at 36 C.F.R. pts. 217, 219). 
tory process costs ${ }^{65}$ or the prospect of immediate judicial review, ${ }^{66}$ an agency instead may prefer to develop and communicate policy through less formal guidances, internal directives and handbooks, socalled "letter rulings," or unwritten criteria passed on by telephone or meeting. These less formal policymaking devices can "overwhelm[] the more formal output." 67 Peter Strauss has estimated that Federal Aviation Administration legislative rules, including those governing aircraft safety, occupy two inches of shelf space, while corresponding nonbinding technical guidance materials take up "well in excess of forty feet." ${ }^{\prime 6}$ Similar examples abound at other federal agencies, ranging from the Forest Service, which relies on nonbinding "Forest Service Directives," to the Office of Thrift Supervision of the Treasury Department, whose examiners of insured thrifts are guided by an internal handbook known as the Holding Companies Handbook. ${ }^{69}$ Although these materials can inform the public regarding an agency's likely implementation of its programs, they very often expressly disclaim any binding effect upon the agency, ${ }^{70}$ and courts

65 Considerable commentary has focused on the cost and time required to complete informal rulemaking. Compare McGarity, supra note 47 (arguing that requirements for rulemaking process are overly stringent and that rulemaking process accordingly has "ossified"), with Peter L. Strauss, The Rulemaking Continuum, 41 Duke L.J. 1463, 1470-71 (1992) (contending that rulemaking "ossification" is limited phenomenon).

66 A court may well find that that a guidance either is not "final agency action" or is not ripe for review until it is applied in the context of a particular case. See, e.g., Clean Air Implementation Project v. EPA, 150 F.3d 1200, 1207-08 (D.C. Cir. 1998) (finding agency preamble statement not "definite and specific enough to be a binding statement of agency policy" and thus not ripe for review); N.Y. Stock Exch. v. Bloom, 562 F.2d 736, 741-43 (D.C. Cir. 1977) (finding informal opinion letter not ripe for review, in part because agency reserved possibility of position change).

67 Strauss, supra note 65, at 1469 (presenting anecdotal evidence of "extraordinary volume of [informal] standard-generating activity" that dwarfs standard-setting through formally adopted regulations).

68 Id.

${ }^{69}$ See Office of Thrift Supervision. Holding Companies Handbook $\S 100$ (2002), http:// www.ots.treas.gov/docs/4210001.pdf.

70 See, e.g., EPA, Welcome to the Interpretive Documents Collection, at http://www. epa.gov/guidance (last visited Apr. 8, 2003) ("Disclaimer: The documents provided here do not substitute for EPA's regulations; nor are they regulation [sic] themselves. Thus, they cannot impose legally binding requirements on EPA, the states, tribes or the regulated community ...."); FDA, Compliance Policy Guides Introduction, at http://www.fda.gov/ ora/compliance_ref/cpg/introduction.html (last visited Apr. 8, 2003) ("The statements made in the CPG are not intended to create or confer any rights, privileges, or benefits on or for any private person, but are intended for internal guidance."); Fed. Aviation Admin., U.S. Dep't of Transp., Advisory Circular No. 25.1523-1, Minimum Flightcrew 1 (1993), http://www.airweb.faa.gov/Regulatory_and_Guidance_Library/rgAdvisoryCircular.nsf/0/ 09c6a3dfebf5af53862569d1007336c6/\$FILE/AC25.1523-1.pdf ("[Advisory circular] is not mandatory and does not constitute a regulation. It is for guidance purposes only."); OSHA, U.S. Dep't of Labor, Small Entity Compliance Guide for the Revised Respiratory Protection Standard 5 (1998), http://www.osha.gov/Publications/secgrev-current.pdf (stat- 
generally will not require an agency to act in accordance with them. ${ }^{71}$

At bottom, the comparative lack of binding procedures and decision criteria, whether from outside institutions or from the agencies

ing Guide "provides guidance only, and does not alter or determine compliance responsibilities ... . [T] he reader must refer to the [regulatory] standard to ensure compliance"). But see Interpretation of Medicaid Days in Medicare DSH Adjustment Calculation, HCFA Ruling No. 97-2 [Dec. 1996-June 1997 Transfer Binder] Medicare \& Medicaid Guide $(\mathrm{CCH})$ If 45,105 (Feb. 27, 1997) ("HCFA Rulings [including statements of policy and interpretation] are binding on all HCFA components, ... [including] the Departmental Appeals Board, and Administrative Law Judges who hear Medicare appeals.").

71 See, e.g., Schweiker v. Hansen, 450 U.S. 785, 789 (1981) (per curiam) (holding that Social Security Administration Claims Manual is without legal effect); Edwardsen v. U.S. Dep't of the Interior, 268 F.3d 781, 786 (9th Cir. 2001) (ruling that Interior Department handbook on environmental review is not binding); Hudson v. Fed. Aviation Admin., 192 F.3d 1031, 1034 (D.C. Cir. 1999) (determining that Federal Aviation Administration policy statement is not binding); Green v. St. Louis Hous. Auth., 911 F.2d 65, 72 (8th Cir. 1990) (concluding that Housing and Urban Development (HUD) handbook did not create property interest in agency job); Gatter v. Nimmo, 672 F.2d 343, 347 (3d Cir. 1982) (deciding that Department of Veterans Affairs lenders' handbook and circulars did not create enforceable duty on agency to help veteran borrower avoid foreclosure).

Courts sometimes have vacated an agency guidance for failure to comply with APA procedural requirements when the agency acts as if the guidance were a rule by arguing, for example, that private parties are legally bound by it. Compare Gen. Elec. Co. v. EPA, 290 F.3d 377, 385 (D.C. Cir. 2002) (vacating EPA guidance document on PCB disposal methods for failure to comply with notice-and-comment rulemaking), and Cmty. Nutrition Inst. v. Young, 818 F.2d 943, 948-49 (D.C. Cir. 1987) (per curiam) (vacating Food and Drug Administration (FDA) "action levels" for failure to comply with APA notice-and-comment rulemaking requirements), with U.S. Dep't of Labor v. Kast Metals Corp., 744 F.2d 1145, 1156 (5th Cir. 1984) (stating OSHA did not need to perform APA rulemaking for rule prioritizing employers for workplace safety investigations). See also Jon Connolly, Note, Alaska Hunters and the D.C. Circuit: A Defense of Flexible Interpretive Rulemaking, 101 Colum. L. Rev 155 (2001) (criticizing rare court opinions that appear to require noticeand-comment rulemaking to revise certain interpretive rules).

Only in rare circumstances--when an agency evinces an intent that the document is mandatory-may a court require it to comply with an ordinarily nonbinding manual or handbook. See, e.g., Morton v. Ruiz, 415 U.S. 199, 235 (1974) (striking down Bureau of Indian Affairs action denying individual benefits for failure to comply with publication requirement contained in unpublished agency manual); Vietnam Veterans of Am. v. Sec'y of the Navy, 843 F.2d 528, 536-37 (D.C. Cir. 1988) (listing cases in which internal rules were binding); Doe v. Hampton, 566 F.2d 265, 281 (D.C. Cir. 1977) (remanding for determination of whether Personnel Manual statements were "mandatory" or "precatory"). However, an agency's use of the word "should" rather than "must" in describing an agency employee's obligation probably is sufficient to preclude such a finding. Hampton, 566 F.2d at 281. Peter Strauss has argued for "precedential" value for such agency statements. Peter L. Strauss, Publication Rules in the Rulemaking Spectrum: Assuring Proper Respect for an Essential Element, 53 Admin. L. Rev. 803, 850 (2001) (advocating use of "model of precedent"); Strauss, supra note 65, at 1472 (arguing that, in view of language of APA, "the question of what jural effect to give to publication rules is not settled").

Generally, though, courts are interested in encouraging agencies to provide guidance to their thousands of employees without creating concern that a slip-up will lead to liability. See, e.g., Schweiker, 450 U.S. at 790 n.5 (remarking that it is better to have nonbinding guidance and tolerate occasional erroneous administration than to have no rules at all). 
themselves, leaves agencies considerably freer to make decisions (or to avoid making them) on an ad hoc basis, serving narrow interest group goals or pursuing so-called Burkean notions of the public interest-those defined with no regard for public preference, but based only on the views of the decisionmaker. ${ }^{72}$ Individual agency employees may deviate more easily from articulated agency policies or simply ignore problems altogether. ${ }^{73}$ Both those regulated by the government and those that expect to benefit from regulation may end up distrusting administrative agencies. ${ }^{74}$

72 See, e.g., Martin Shapiro, Administrative Discretion: The Next Stage, 92 Yale L.J. 1487, 1500-19 (1983) (describing agency action as "marbled" through with discretion and cataloging forms of agency discretion). There is, of course, a vast literature on what it means for a policy to be in the "public interest": whether it is the policy with the maximum social utility, the policy the public itself would ratify, what an elected, deliberative body such as Congress would select, or something else. See, e.g., Hanna F. Pitkin, The Concept of Representation 197 (1967) (describing Burkean representative as one that "know[s] his constituents' interests better than they do themselves"); Michael E. Levine \& Jennifer L. Forrence, Regulatory Capture, Public Interest, and the Public Agenda: Toward a Synthesis, 6 J.L. Econ. \& Org. 167, 176 (1990) ("General-interest policies . . are those . . that would be ratified by the general polity according to its accepted aggregation principles if the information, organization (including exclusion costs), and transaction and monitoring costs of the general polity were zero."); Seidenfeld, supra note 44, at 474 ("Agency discretion may permit regulation that promotes administrators' idiosyncratic values ... [that are] inconsistent with those held generally by the polity."); Seidenfeld, supra note 48 , at 1528 (arguing that civic republican theories do not posit external conception of common good but "embrace[] an ongoing [and inclusive] deliberative process ... to arrive at the public good"); David B. Spence \& Frank Cross, A Public Choice Case for the Administrative State, 89 Geo. L.J. 97, 106 (2000) (describing assumption that "[v]oters want government to do what they would have done if they had the time and resources to devote to the problem").

One commentator has argued that a variety of developments, including greater judicial, presidential, and congressional supervision, have "amount[ed] to a broad rejection of administrative autonomy." Sunstein, supra note 39 , at 934 . While other institutions occasionally have exercised greater control over agencies, agencies still retain substantial autonomy and discretion. For example, Sunstein himself acknowledges "prominent recent signs of more judicial modesty." Id. at 936 \& n.47 (citing Chevron U.S.A. Inc. v. Natural Res. Def. Council, Inc. 467 U.S. 837 (1984)); see also Mashaw, supra note 46, at 84 (characterizing antidelegation critics as describing administrative state in which the "legitimacy and efficacy [of administrators] will be deeply compromised by their lack of clear statutory authority"). But see Antonin Scalia, The Doctrine of Standing as an Essential Element of the Separation of Powers, 17 Suffolk U. L. Rev. 881, 897 (1983) (observing positive consequences from agencies losing programs).

73 Seidenfeld argues that indirect methods of changing policy can "allow improper political influence over agency decisions," pointing to the example of the Bellmon Review program in the Reagan Social Security Administration. See Seidenfeld, supra note 44, at 469.

74 See Lowi, supra note 46 , at 149 (asserting agency effort to avoid enunciating rule can "end in reduced respect-for the agency and for government"). 
Given the limited prospect of greater congressional control over agencies ${ }^{75}$ coupled with the broad discretion possessed by agencies and the deference that courts typically give to agencies, what can serve as a source of legitimacy for the "fourth branch"?76 Commentators have developed a range of approaches to the legitimacy of the administrative state. In each, however, the relationship of the President to the agencies plays a significant, even central, role.

\section{B. Agencies, Legitimacy, and the President}

The broad discretion currently possessed by agencies has sharpened the question of the administrative state's legitimacy, ${ }^{77}$ to which I now turn. In my view, legitimacy can be assessed by answering two component questions: (1) Can agency power be characterized as democratic, especially if Congress, the closest institution to the electorate, is not making key policy decisions, and (2) are agencies accountable for the power they exercise ${ }^{78}$ As described in more detail below, an assessment of whether an agency is democratic in nature should consider not only the method of selecting its leadership, but also the question of whether individual agency decisions can be characterized as democratically responsive. ${ }^{79}$

The accountability question focuses on whether an agency is obligated to disclose and justify its actions and whether its authority can be seen as limited by meaningful constraints, be they internal or exter-

75 See, e.g., Richard B. Stewart, The Reformation of American Administrative Law, 88 Harv. L. Rev. 1667, 1712 (1975) (finding acceptance of agency control "inevitable . . . [given] the inability of Congress ... to fashion precise directives").

76 Cf. Fed. Mar. Comm'n v. S.C. State Ports Auth., 535 U.S. 743, 773, (2002) (Breyer, J., dissenting) (arguing that while "[m]embers of this Court have referred to agencies as a 'fourth branch' of Government, the agencies ... are more appropriately considered to be part of the Executive Branch" (citations omitted)).

$77 \mathrm{Cf}$. Mashaw, supra note 46, at 83 (discussing Lowi's view that reliance on law would "produce government whose legitimacy was more widely recognized by the electorate").

78 Regulatory efficiency, while a laudable goal and one that certainly should be a focus for designers of agency structure, is not a focus of this Article. Cf. Kagan, supra note 52, at 2331 ("All models of administration must address two core issues: how to make administration accountable to the public and how to make administration efficient or otherwise effective.").

79 Pitkin, supra note 72, at 232 (arguing that true political representation requires that government does not "merely promote the public interest, but [also is] responsive to the people"); see also Guido Calabresi, A Common Law for the Age of Statutes 51 (1982) ("[T]he question therefore becomes: Can these agencies sufficiently discern shifts in majoritarian demands to make them reliable updaters of those preferential treatments that our legal system must have?"); Jerry L. Mashaw, Small Things Like Reasons Are Put in a Jar: Reason and Legitimacy in the Administrative State, 70 Fordham L. Rev. 17, 21 (2001) ("Administrators, of course, have two possible connections to the electorate: the appointment of all high level administrative personnel by the President and the ultimate derivation of virtually all administrative authority from the legislature."). 
nal. ${ }^{80}$ Accountability is closely related to the extent to which outside institutions can check agency conduct. That in turn will increase with the amount of information available to outside institutions and the public at large. Accountability also increases with the rule of law: the extent to which agency discretion can be measured against determinate, publicly announced, and enforceable criteria.

Accountability and democracy are linked in two ways. On the one hand, to the extent an agency's power is constrained by the rule of law, rather than being an arbitrary exercise of discretion, the electorate may perceive the agency's actions as more legitimate. ${ }^{81}$ On the other hand, the electoral process itself can supply one form of accountability. For example, a change in Congress or the presidency may result in closer oversight of the agency's performance. Again, commentators have seen a key - and in some cases central-role for the President in providing agencies with legitimacy.

\section{Conceptions of Democracy in the Agency Context}

Consider at the outset two major conceptions of democracy. First, under a more pluralistic conception of democracy, an institution, such as Congress or an agency, might be characterized as democratic to the extent its policy decisions can be seen as expressions of the popular will. The pluralist conception of democracy acknowledges a wide array of interests in society and characterizes as democratic an institution that is aware of and responds to those interests in the context of particular policy decisions. ${ }^{82}$ An institution's policy decisions may be characterized as democratic because they are consistent with the preferences of most voters. ${ }^{83}$ The democratic character of the in-

80 See Gerald E. Frug, The Ideology of Bureaucracy in American Law, 97 Harv. L. Rev. 1276, 1284 (1984) (observing that various models of administrative agencies are aimed at saying bureaucracies are "under control").

81 See supra note 77 (citing Mashaw's discussion of Lowi); see also Frug, supra note 80, at 1285 (noting that compliance with rule of law can confer legitimacy).

82 See, e.g., William N. Eskridge, Jr., Public Values in Statutory Interpretation, 137 U. Pa. L. Rev. 1007, 1069 (1989) ("A pluralist views government as a means to resolve interest group clashes and views legislation as typically a 'deal' between legislators and interest groups. The goal of the pluralist system is not to surpass, but to survive; not to produce optimally rational, public-seeking statutes ...."); Stewart, supra note 75, at 1683 (seeing administrative process as "legislative process of adjusting the competing claims of various private interests affected by agency policy"); see also Jeremy Waldron, Deliberation, Disagreement, and Voting, in Deliberative Democracy and Human Rights 210, 211 (Harold Hongju Koh \& Ronald C. Slye eds., 1999) (maintaining that pluralism refers to "theory of democracy that proposes to handle such interests on their own terms and not to try to transform them").

83 See, e.g., Cass R. Sunstein, The Partial Constitution 163 (1993) ("In a good deal of contemporary thought, respect for existing preferences is a major theme."). Unlike civic republican theories, pluralist theories see individual preferences as independent and not 
stitution additionally might be inferred from a procedural feature: If the institution's membership is selected by the electorate, it can be turned out of office for failing to enact appropriate policies. ${ }^{84}$ True responsiveness to a wide variety of interests in turn minimizes one of the dangers seen by a pluralistic conception of democracy: the likelihood that a few factions will dominate the political process inappropriately. ${ }^{85}$

Democracy also can be seen, however, "not simply in terms of popular will and decision, but as a form of legitimation of power that depends on a conception of public justification and deliberative reason." 86 On this more republican view, advanced by commentators such as Amy Gutmann and Dennis Thompson, an institution like Congress might be perceived as democratically legitimate to the extent its process is deliberative and proposed decisions are justified with publicly articulated reasons. On such a view, public opinions about the common good may be transformed through the process of discussion, and both citizens and representatives may be encouraged to think more generously about the claims of those with whom they disagree; this deliberative process itself may help develop civic virtue. ${ }^{87}$ Moreover, those whose views or opinions are not transformed or adopted still may find the process legitimate because they perceive that their views were responded to on the merits. ${ }^{88}$ Gutmann and Thompson further argue that democracy requires not merely a deliberative process within a representative institution, but a deliberative process that engages both the institution and the citizens themselves. ${ }^{89}$

\section{The Administrative State as the Agent of an Elected President}

How can administrative agency authority be conceptualized as legitimate, consistent with these views of democracy? A principal set of

subject to transformation through the political process. See Eskridge, supra note 82, at 1071-72.

84 Cf. Amy Gutmann \& Dennis Thompson, Democracy and Disagreement 137 (1996) (describing procedural democracy as ensuring accountability for policies and results); Pitkin, supra note 72 , at 232 (claiming representative government is responsive to people).

85 See, e.g., The Federalist No. 10 (James Madison).

86 Robert Howse, Democracy, Science, and Free Trade: Risk Regulation on Trial at the World Trade Organization, 98 Mich. L. Rev. 2329, 2334 (2000); see also Dan M. Kahan, Democracy Schmemocracy, 20 Cardozo L. Rev. 795, $796-97$ (1999) (describing civic republican view of democracy reaching decisions through process of "reflective deliberation on the 'common good").

87 See Eskridge, supra note 82, at 1015-16 (discussing civic republican ideal of transforming private preferences as citizens deliberate about both "common good and the moral content of their society").

88 See Gutmann \& Thompson, supra note 84 , at $16,40-41$.

89 Id. at $12-13$. 
justifications evaluates the legitimacy of administrative agencies by assessing their accountability to another institution that can be readily characterized as democratic. For example, under the so-called "transmission belt" model, in Dick Stewart's words, Congress makes key social policy decisions, and the administrative agency's function is simply to make those policies concrete through the objective and technical decisions necessitated in implementation. ${ }^{90}$ Administrative agency authority requires no independent source of democratic legitimacy; the agency performs technical tasks that merely carry out the wishes of the popularly elected Congress. ${ }^{91}$ Similarly, the administrative agency's discretion is confined within "identifiable and determinate bounds." 92 The question of democratic responsiveness and accountability then becomes essentially a principal-agent problem. On such a view, the central question therefore is whether the administrative agency will be obligated to implement faithfully the congressionally chosen policies. ${ }^{93}$

The congressional "transmission belt" model has largely been abandoned by the literature in recognition of the breadth and vagueness of congressional delegations of authority to administrative agencies, the doubtful prospects for closer congressional control, and the inevitably subjective and value-laden, rather than exclusively technical, nature of bureaucratic policy decisions. ${ }^{94}$ Its conception of administrative agency legitimacy as a principal-agent problem involving Congress now survives primarily in commentary advocating closer congressional control over agencies. ${ }^{95}$

Instead, the dominant version of the principal-agent approach to the democratic legitimacy of administrative agencies is now the presidential control model. Scholars such as Jerry Mashaw have argued that presidential control over an executive branch agency adequately

90 Stewart, supra note 75 , at $1675-76$; see also Mashaw, supra note 50, at 111 (noting that from 1930 s through early 1970 s, administrative state was seen as "well-ordered input/ output machine").

91 See Frug, supra note 80 , at 1282 (describing theories which conceptualize agencies as "objective instruments under the control of those who delegated power to them").

92 Lisa Schultz Bressman, Beyond Accountability: Arbitrariness and Legitimacy in the Administrative State, 78 N.Y.U. L. Rev. 461, 470 (2003).

93 This theory need not specify whether Congress is acting as a deliberative body or according to a more pluralist model.

94 See Stewart, supra note 75, at 1676 ("[B]oth the checking and validating functions of the traditional model are impaired."). To the extent some theories relied on the inherent professionalism of agency staffs to motivate them to toe the line set by Congress, recognition that agency decisions inherently contained value questions as well as technical questions undermined that reliance. See Seidenfeld, supra note 46, at 33-34.

95 See supra notes $44-49$ and accompanying text. As noted above, however, congressional control over agencies seems unlikely to be truly close or systematic. See supra notes 62-63 and accompanying text. 
assures-indeed, perhaps better assures-democratic responsiveness than close accountability to Congress. ${ }^{96}$

Presidential control over agencies is potentially extensive. Although she cannot legislate, the President can, of course, hold an executive branch agency accountable through the power to replace the top management of an agency. ${ }^{97}$ Moreover, congressional delegations of authority often are made directly to the President, leaving the President free to decide to which executive branch agency the power will be redelegated. ${ }^{98}$ Even if Congress delegates authority to an agency head, rather than the President, ${ }^{99}$ post-New Deal delegations almost certainly are granted with awareness of presidential removal authority and the policy-coordinating and supervising functions typically performed by the White House. ${ }^{100}$ Besides exercising the power to re-

96 See Mashaw, supra note 50, at 153. For example, in 1987. Sunstein observed that "issues of policy, or judgments of value . . . cannot be resolved solely by application of technical expertise .... In these circumstances it becomes all the more important to ensure that regulatory choices are made by officials subject to the control of a politically accountable actor. The President is the logical candidate." Sunstein, supra note 39, at 944-45; see Cynthia R. Farina, The Consent of the Governed: Against Simple Rules for a Complex World, 72 Chi.-Kent L. Rev. 987, 988 (1997) ("Increasingly, scholars (and, at times, the judiciary) look to the President not only to improve the managerial competence and efficiency with which regulation occurs but also, and more deeply, to supply the elusive essence of democratic legitimation.").

97 This Article will not deal with the particular problems presented by the "independent" agencies. See generally Peter L. Strauss, The Place of Agencies in Government: Separation of Powers and the Fourth Branch, 84 Colum. L. Rev. 573, 589-91 (1984) (noting that independent agencies possess some greater freedoms from presidential control but that presidential influence is heightened by "special ties" between President and chairs of "almost all the independent regulatory commissions").

98 See, e.g., Comprehensive Environment Response, Compensation, and Liability Act, Pub. L. No. 96-510, $\$ 104($ a), 115, 94 Stat. 2762, 2774-75, 2796 (codified at 42 U.S.C. $\S \S 9604(\mathrm{a}), 9615$ (2000)) (authorizing President to remediate hazardous substances, to issue regulations, and to delegate her duties).

Some commentators have argued that the Constitution requires a "unitary executive." The theory implies a limit on congressional ability to bypass the President by, for example, delegating authority exclusively to an agency head or by creating independent agencies. See generally Steven G. Calabresi \& Saikrishna B. Prakash, The President's Power to Execute the Laws, 104 Yale L.J. 541 (1994) (presenting historical arguments in favor of unitary executive reading of Constitution); Lawrence Lessig \& Cass R. Sunstein, The President and the Administration, 94 Colum. L. Rev. 1 (1994) (presenting historical arguments against unitary executive theory). Even if the Constitution does not require Presidential control, however, Congress's statutory delegations of authority generally either explicitly or implicitly contemplate it. See Kagan, supra note 52, at 2331-45; see also Sunstein, supra note 39, at 945 ("Perhaps the best solution would be to interpret the governing statutes as granting the President some measure of control over the independent agencies.").

99 See, e.g., Federal Water Pollution Control Act $\$ 402,33$ U.S.C. $\$ 1344$ (2000) (authorizing Secretary of Army to issue permits to deposit fill material into waters of United States).

100 There is a long history of presidential control over agencies, concerning which congressional awareness might reasonably be presumed. While the Reagan, George H.W. 
move an executive branch agency head at will, the Executive Office of the President now systematically reviews agency regulatory activity, ${ }^{101}$ controls agency budget requests, requires agencies to report on their performance, and attempts to counteract "bureaucratic inertia" by supervising agency priority-setting. ${ }^{102}$ Presidents sometimes exert supervisory authority over independent agencies as well. ${ }^{103}$ Mashaw and others have argued that this presidential control of agency policy decisions provides agencies with meaningful political accountability. ${ }^{104}$ The electorate communicates ex ante policy preferences through the presidential election, choosing the candidate whose proposed policies will best embody its preferences (or whose appointees

Bush, and Clinton administrations centralized the supervision of executive branch policymaking perhaps more formally and more successfully than earlier administrations, previous Presidents certainly engaged in such supervision. See, e.g., Sierra Club v. Costle, 657 F.2d 298, 387-89 (D.C. Cir. 1981) (discussing Carter White House involvement in development of air quality regulation); Louis Fisher, The Politics of Shared Power: Congress and the Executive 140 (4th ed. 1998) ("The White House staff expands into a counter-bureaucracy to control unruly departments and agencies." (citing reports of Nixon administration)). Fisher notes that various Attorneys General advised that Presidents could not interfere with agency functions if Congress had identified the agency head, rather than the President, as the recipient of the delegation. However, these opinions were all written before 1900. Fisher, supra, at 129 \& nn.98-99. In this century, the Department of Justice's Office of Legal Counsel has advised the President that close supervision of agency policy decisions is completely appropriate. See Proposed Executive Order Entitled "Federal Regulation," 5 Op. Off. Legal Counsel 59, 60-64 (1981) (concluding that presidential powers properly include supervision of executive agency rulemaking). Elena Kagan has argued persuasively on policy grounds, moreover, that even where direct evidence of congressional intent is lacking, the best reading of these statutes permits presidential supervision. See Kagan, supra note 52, at 2331-45; see also Thomas O. McGarity, Presidential Control of Regulatory Agency Decisionmaking, 36 Am. U. L. Rev. 443, 444 (1987) (taking issue with proposition that Congress lacks power to limit presidential attempts to control executive agency decisionmaking).

Furthermore, while Congress has created and delegated authority to "independent" agencies, whose heads are not subject to at-will removal by the President, the proportion of delegations represented by authority grants to independent agencies has been shrinking. See Kagan, supra note 52, at 2274 n.104 (arguing that commentary's focus on independent agencies is "all the more misdirected in light of the gradual transfer of power from independent to executive branch agencies").

101 See Exec. Order No. 12,866, 3 C.F.R. 638 (1993), reprinted in 5 U.S.C. $\$ 601$ (2000) (Clinton order on regulatory review); Exec. Order No. 12,291, 3 C.F.R. 127 (1981), reprinted in 5 U.S.C. $\$ 601$ (1988) (Reagan order on regulatory review).

102 See Kagan, supra note 52, at 2339 (arguing that presidential control can have significant benefits for agency functions). For an extensive catalogue of recent mechanisms of presidential control, see id.; Sunstein, supra note 39, at 937-40. Moreover, executive branch agencies must clear legislative matters with the Office of Management and Budget. See Strauss, supra note 97 , at 588 .

103 See, e.g., Sunstein, supra note 39, at 938 (discussing President's ability to "energize and direct regulatory policy").

104 See, e.g., Cynthia R. Farina, Faith, Hope, and Rationality or Public Choice and the Perils of Occam's Razor, 28 Fla. St. U. L. Rev. 109, 125 (2000) (remarking that some commentators have identified President as public-regarding "white knight"). 
will try to develop such policies). ${ }^{105}$ The President thus is a conduit for popular views. Furthermore, she likely will remain responsive to electoral views through her term to increase the chances of her reelection or to maintain her party's continued control of the presidency. ${ }^{106}$

Some commentators go even further, arguing that the political accountability supplied by the President is not simply an adequate substitute for that flowing from Congress, but that the President will be a better conduit for public preferences because she will be better able to counteract narrow regional interests and the demands of small groups of constituents. ${ }^{107}$ Moreover, vague statutory delegations (though they represent less congressional control) may actually facilitate political accountability, as agencies, through presidential control, can be more responsive to electoral preferences that shift over time. ${ }^{108}$ Implicitly, the agency's democratic legitimacy here is not ensured by the President's mere selection of the agency head. Instead, the argument is that the connection with the President will make the agency

105 See, e.g., Mashaw, supra note 50, at 27 (describing public choice theory as seeing "individuals relentlessly pursuing their own exogenously determined individual preferences"); Mashaw, supra note 46, at 95 ("Citizens vote for a president based almost wholly on a perception of the difference that one or another candidate might make to general governmental policies.").

106 Sunstein, supra note 39, at 938 (discussing electoral accountability of President and arguing that "his institutional position tends to make him particularly concerned about public reaction").

107 Mashaw, supra note 46, at 95 ("The president has no particular constituency to which he or she has special responsibility to deliver benefits."); see also Farina, supra note 96, at 991 (same); Farina, supra note 104, at 125-26 ("Enhanced presidential control over regulatory policymaking is advocated as the means through which the interests of the nation can triumph over the geographical parochialism and special-interest pandering that drive the rest of the political process."); Terry M. Moe, The Politics of Bureaucratic Structure, in Can the Government Govern? 267, 279 (John E. Chubb \& Paul E. Peterson eds., 1989) ("[P]residents have incentives to think in grander terms about what is best for society as a whole, or at least broad chunks of it, and they have their own agendas ....").

108 Richard W. Waterman, Presidential Influence and the Administrative State 14-15 (1989) (noting that Presidents have attempted to justify executive branch influence by arguing they are only officials, except Vice President, elected by national constituency); Mashaw, supra note 46, at 96 (stating that "the flexibility that is currently built into the processes of administrative governance by relatively broad delegations of statutory authority permits a more appropriate degree of administrative, or administration, responsiveness to the voter's will" and maintaining that advantage is pronounced when legislative transaction costs are taken into account).

This Article does not delve into the question of whether a government action that directly serves electoral preferences also can be said to be in the "public interest." Cf. Kahan, supra note 86, at 796-97 (comparing pluralist evaluation of democratic government-"extent to which official decisions conform to the aggregated preferences of the electorate"-with that of civic republicans). But at a minimum, voters are more likely to perceive that government action serves the public interest if the government at least considers electoral preferences, whether or not the decision ultimately conforms to what voters would select in a referendum. 
democratically responsive, either because the President serves as a conduit for electoral preferences or because the President has the incentive to compel the agency to detect and respond to those preferences.

Theoretically, Presidents could also effectively call agencies to account for their exercises of discretion. Mark Seidenfeld has claimed that due to the hierarchical arrangement of the executive branch, "if any single institution is well suited for monitoring overall government policy, it is the White House."109 Presidential executive orders have gone beyond statutes by requiring regulatory review as well as analysis of substantive issues, such as the impact of proposed actions on state governments. ${ }^{110}$ With presidential control, agency policymaking is arguably not only less arbitrary, but relatively efficient. In addition to democratically legitimating agencies, presidential supervision can impose discipline upon agencies and perhaps efficiencies even superior to congressional decisions on the same questions. Jerry Mashaw, for example, points to cost-benefit analysis requirements. ${ }^{111}$ These types of requirements, together with the incentive for an agency to explain its reasoning at the time of decision in order to withstand later judicial review, ${ }^{112}$ arguably reduce the sum of error, decision, and agency costs compared with the costs of Congress making the same sorts of decisions. ${ }^{113}$

The Supreme Court has found presidential control over agencies to be a critical element of their legitimacy. The Court in Chevron U.S.A. Inc. v. Natural Resource Defense Council, Inc., identified the agency-electorate connection, through the President, as a reason for courts to defer to agency interpretations of the statutes they administer: "While agencies are not directly accountable to the people, the

109 Seidenfeld, supra note 46 , at 12 . See generally supra text accompanying notes 116-21 (discussing Seidenfeld's civic republican view of agencies).

110 See supra text accompanying notes 101-02.

111 Mashaw, supra note 50, at 149; see Exec. Order No. 12,866, 3 C.F.R. 638, 640 (1993), reprinted in 5 U.S.C. $\$ 601$ (2000) (setting forth regulatory review requirements).

112 See Citizens to Pres. Overton Park, Inc. v. Volpe, 401 U.S. 402 (1971) (reviewing agency decision on its record); SEC v. Chenery Corp. (Chenery I), 318 U.S. 80 (1943) (reviewing agency decision based on reasons stated by agency); United States v. Nova Scotia Food Prods. Corp., 568 F.2d 240 (2d Cir. 1977) (requiring agency to explain underlying reasoning and respond to significant comments).

113 See Mashaw, supra note 50, at 149. Peter Schuck also argues that for prospective participants in a policy debate, the costs of participating in an agency process are lower than the costs of participating in a congressional process. See Peter H. Schuck, Delegation and Democracy: Comments on David Schoenbrod, 20 Cardozo L. Rev. 775, 781 (1999). 
Chief Executive is, and it is entirely appropriate for this political branch of the Government to make such policy choices . . .."114

\section{Agency-Centered Conceptions of Legitimacy in the Administrative State}

The prospect that agency burrowing undermines agency responsiveness to a new President is obviously significant if one adopts a presidential control model of the administrative state. However, the President also plays an important role under other, less dominant justifications of the administrative state. The transmission belt theory and the presidential control theory described above conceive of the administrative state's legitimacy as an agency problem, relying primarily on its accountability to more democratic institutions such as Congress or the President. By comparison, other conceptions of democratic legitimacy rest more directly on the decisionmaking processes of the agencies themselves. ${ }^{115}$

For example, civic republican theorists, such as Mark Seidenfeld, find the location of democratic deliberations to be not in Congress but within the agencies themselves. Seidenfeld has argued that the administrative state's decisionmaking processes can be conceptualized as a deliberative process that offers the "best hope of implementing civic republicanism's call for deliberative decisionmaking informed by the values of the entire polity." 116 The civic republican approach claims as a positive feature some political insulation of policymaking agencies, at least from Congress. In the absence of detailed congressional

114 Chevron U.S.A. Inc. v. Natural Res. Def. Council, Inc., 467 U.S. 837, 865 (1984); see also FDA v. Brown \& Williamson Tobacco Co., 529 U.S. 120, 190 (2000) (Breyer, J., dissenting) ("Insofar as the decision to regulate tobacco reflects the policy of an administration, it is a decision for which that administration, and those politically elected officials who support it, must (and will) take responsibility."); Motor Vehicle Mfrs. Ass'n v. State Farm Mut. Auto. Ins. Co., 463 U.S. 29, 59 (1983) (Rehnquist, J., concurring in part and dissenting in part) ("A change in administration brought about by the people casting their votes is a perfectly reasonable basis for an executive agency's reappraisal of the costs and benefits of its programs and regulations."); John F. Manning, Constitutional Structure and Judicial Deference to Agency Interpretations of Agency Rules, 96 Colum. L. Rev. 612, 626 (1996) ("[The Chevron Court] emphasized that our constitutional system favors relatively more accountable agencies, and not relatively less accountable courts, as repositories of policymaking discretion."); Thomas W. Merrill, Judicial Deference to Executive Precedent, 101 Yale L.J. 969, 978-79 (1992) (arguing that "agency decisionmaking is always more democratic than judicial decisionmaking because all agencies are accountable (to some degree) to the President").

115 See, e.g., Spence \& Cross, supra note 72, at 101 (remarking that their theory and Seidenfeld's civic republican theory do "not predicate the legitimacy of agency autonomy on the assumption that Congress or the President effectively controls agency policy choices").

116 Seidenfeld, supra note 48 , at 1515 . 
policy decisions, agencies can discern the polity's values through public participation in agency decisionmaking, including through the notice-and-comment rulemaking requirements. Seidenfeld maintains that agencies will be motivated to do so because bureaucrats generally will be professional and public-interest-minded. ${ }^{117}$

While such a decisionmaking process offers the prospect of legitimacy through a deliberative, reason-giving lens, Seidenfeld identifies the danger that an insulated decisionmaking process can lead to "undemocratic outcomes" 118 by straying too far from "consensus values."119 Such straying might occur either because the agency's dialogue is not fully informed by the appropriate range of information or viewpoints ${ }^{120}$ or because the agencies "pursue their own goals and agendas." 121

This type of civic republican view sees presidential control not as the central source of legitimacy, but as a safeguard against poor outcomes or skewed deliberation. The President can serve as a means of "cabin[ing] agency decisionmaking" 122 and bringing "the values of the electorate to bear," 123 through White House review of agency policy and the President's ability to appoint agency officials that share "relevant basic values and public aspirations" with the national electorate. ${ }^{124}$ Congress theoretically could serve such a function as well, but legislative overrides of agency action are likely to "occur infrequently." 125 In short, the argument is that the President's function is to help ensure the appropriate conditions for deliberation and to act

117 Id. at 1555 ("Staff bureaucrats focus on what they believe the public interest is and whether the suggested policy furthers it.").

118 Id. at 1540 .

119 Id. at 1550 .

$120 \mathrm{Cf}$. id. at 1528 (noting that agency setting offers opportunity to create dialogue "inclusive of all cultures, values, needs, and interests").

121 Id. at 1554. For example, an agency might wish to make the performance of agency missions easier by expansively interpreting its enforcement authority. See Spence \& Cross, supra note 72 , at 113 .

122 Seidenfeld, supra note 48 , at 1551 .

123 Id. at 1552.

124 Id. at 1554. But see Seidenfeld, supra note 44 , at 477 (outlining difficulties President might face in relying on lower-level agency employees as monitors). For example, Seidenfeld argues in the context of rulemaking that a slightly rejiggered White House regulatory review process could "help prevent agency capture and ideological parochialism." Seidenfeld, supra note 48 , at 1553 .

125 Seidenfeld, supra note 48 , at 1551 . Seidenfeld also observes that an agency may respond to "changes in the make-up and prevailing ideology" of the congressional committee responsible for its appropriation, but notes that the influence of appropriations committees is unclear given the role of the White House in "reviewing and coordinating budget requests." Id. at 1552 . 
as a check, thus ensuring that the product of deliberation will not go too far off the tracks. ${ }^{126}$

Although neopluralist theories of the administrative state place less reliance on the President, they also sometimes conceptualize the President as a safeguard for democratic outcomes. These theories, too, locate decisionmaking within the agencies. Rather than relying on Congress or the President, the agency itself, granted a fair degree of discretion from Congress, may aggregate interests. Interest groups can transmit information and preferences to agencies informally or through participatory processes such as notice-and-comment rulemaking. The agency resembles a microcosm of the legislative process, generating policies that coincide with the popular will. ${ }^{127}$

Of course, that groups have the ability to participate in agency proceedings does not guarantee that the agency will consider all relevant issues. ${ }^{128}$ For example, it is unclear that groups representing the range of relevant viewpoints have the resources or ability to emerge, or whether some interests, such as those diffused among large groups, might be underrepresented in agency proceedings. ${ }^{129}$ Moreover, a familiar insight, related to public choice criticisms of the administrative process, is that agencies could be biased toward well-organized, more narrowly focused interest groups, since those groups may be especially able to provide regulators with information valuable to the agency or to invoke discipline by political branches. ${ }^{130}$

126 Spence and Cross make a similar argument in their public choice-oriented defense of the administrative state. They assert that to the extent agency decisionmakers suffer from value "drift" or an excessive focus upon "agency mission orientation," it can be combated by Congress and by the President. Spence \& Cross, supra note 72, at 120-21. Their primary example is OMB review of proposed agency regulations, which can "directly counteract any bias and provide[] the president with information necessary to evaluate proposed rules." Id. at 121 .

127 See, e.g., Stewart, supra note 75, at 1712 (detailing administrative process similarities to legislative process, assuming Congress has provided fair degree of discretion). Other commentators have extended the theory by identifying steps to enhance agency decisionmaking on this model, such as increasing the diversity of groups represented in agency deliberations. See Ian Ayres \& John Braithwaite, Responsive Regulation: Transcending the Deregulation Debate 83 (1992); Steven P. Croley, Theories of Regulation: Incorporating the Administrative Process, 98 Colum. L. Rev. 1, 59-60 (1998) (arguing that such view compels agencies to act to protect "underrepresented" interests).

128 See, e.g., Stewart, supra note 75 , at 1670.

129 E.g., Croley, supra note 127 , at 58-60.

130 See Steven Croley, White House Review of Rulemaking: An Empirical Investigation, 70 U. Chi. L. Rev. (forthcoming 2003) (describing "informational capture" thesis); Stewart, supra note 75, at 1776-77 (discussing tendency of agencies to favor well-organized interests); Sunstein, supra note 39, at 933-37 (commenting on prospect of agency capture and role of President as check against capture).

A stronger claim, advanced by some adherents of public choice theories, is that agency employees will wish to dispense benefits to such groups to maximize the chance of lucra- 
On these views, as with a civic republican conception of agency function, the President also could serve as a check against system malfunction. The President could offset agency bias toward well-organized groups and provide agencies with a measure of independent initiative. ${ }^{131}$

\section{III}

\section{A Normative Assessment of Agency Burrowing}

Suppose, like the commentators discussed above and like the Court, we rely on the President to ensure that administrative agencies are both democratically responsive and accountable. Perhaps then we should question activities that seem to undermine presidential control over agencies, especially at the time of inauguration. Absent serious dispute over the election process itself, the recentness of the election victory makes the President's democratic credentials at that time nearly incontestable. Our doubtfulness would seem consistent with the cynicism of the popular media and Congress about agency actions that anticipate a presidential transition. ${ }^{132}$

This Part is aimed at evaluating the "hard case" of agency burrowing-the policy or personnel action undertaken with apparent

tive postgovernment employment in the private sector. See, e.g., Richard A. Posner, The Federal Trade Commission, 37 U. Chi. L. Rev. 47, 86-87 (1969) (noting desire of Federal Trade Commission (FTC) lawyers to use government service as stepping stone to private practice). While more parsimonious-because it fits with more general public choice assumptions that individual behavior will be rent-seeking - this claim is fairly unpersuasive. See Steven P. Croley, Public Interested Regulation, 28 Fla. St. U. L. Rev. 7, 30 (2000) [hereinafter Croley, Public Interested Regulation] (arguing that industry would be unlikely to see any further benefit of hiring someone who already had given them what they wanted); Spence \& Cross, supra note 72, at 117 (contending that bureaucratic decisions are not particularly likely to be motivated by "self-interest").

Another version, more closely related to the "transmission belt" model, see supra text accompanying notes $90-93$, is that the self-interest of members of Congress will lead them to enact interest group "deals," the implementation of which will be ensured through administrative process. See Matthew D. McCubbins et al., Structure and Process, Politics and Policy: Administrative Arrangements and the Political Control of Agencies, 75 Va. L. Rev. 431, 436-40 (1989). See generally Mashaw, supra note 50, at 119 (discussing "McNollgast hypothesis"). But see Spence \& Cross, supra note 72, at 130 (asserting, inter alia, that insulation of administrative deliberations from political pressures can reduce power of factions by weakening impact of legislative "interest group deals").

131 See Seidenfeld, supra note 46, at 2 (citing view that President can provide "generalist's perspective to counteract parochial views that particular agencies may develop from ... interacting with a small set of interest groups"); Spence \& Cross, supra note 72, at 121 (noting that Office of Management and Budget review could offset proregulatory biases in agencies); id. at 121 (noting usefulness of political control to offset prospect of agency values drifting away from those of public); see also Stewart, supra note 75, at 1798 (positing presidential accountability of agency heads as check against proposed direct interest group participation in administrative decisionmaking).

132 See supra text accompanying notes 33-38. 
awareness that it will create difficulty for the new President. The new President may find the agencies less responsive and may find that implementing her preferred policies is more expensive. However, a fuller analysis reveals that even such "worst case" agency burrowing can make positive contributions to the legitimacy of agency decisions by enhancing accountability and the democratic responsiveness of the agency. ${ }^{133}$ In some cases, agency burrowing may help inform public debate and thereby engage the public more directly in agency decisionmaking. In other cases, agency burrowing also may assist agency accountability by creating additional monitors of agency activity and prompting agencies to constrain their own discretion.

\section{A. Policy Burrowing and Its Costs}

\section{Characteristic Policy Entrenchment Actions}

Administrative policy entrenchment typically takes the following form: In anticipation of the arrival of a new President, usually in the last several weeks of the outgoing President's administration, ${ }^{134}$ an agency formally and publicly decides a policy question. The agency might issue a rule, policy statement, or guidance, file or settle litigation, or set the terms of a grant competition. The agency generally acts unilaterally, subject to informal White House supervision. ${ }^{135}$ Although such a decision is likely to be reversible at least as a procedural matter, ${ }^{136}$ it is probable that the change will be costly. ${ }^{137}$

133 Cf. Douglas Dion, Turning the Legislative Thumbscrew: Minority Rights and Procedural Change in Legislative Politics 6-9 (1997) (offering critique of the view that legislative process analyses should rely primarily on considerations of efficiency).

134 In some instances policy entrenchment done in anticipation of a new administration can begin even prior to the election. See, e.g., Morrow, supra note 4, at 18 (reporting that, according to Former OMB Acting Deputy Director Sally Katzen, "there have been elections when the likely winner was known soon after the summer conventions").

135 See Exec. Order No. 12,866, 3 C.F.R. 638, 640 (1993), reprinted in 5 U.S.C. $\$ 601$ (2000) (providing for OMB review of agency rules). An agency action may, of course, be subject to later reversal in Congress, see, for example, Congressional Review Act, 5 U.S.C. $\$ \$ 801-808$ (providing for "fast-track" congressional review of agency rulemaking); Helen Dewar, Ergonomics Repeal Prompts Look Back; Democrats Voted for '96 Law GOP Used, Wash. Post, Mar. 9, 2001, at A16 (describing first use of Congressional Review Act to eliminate OSHA "ergonomics rule"), or in the courts, see, for example, $\$ 704$ (agency actions presumptively reviewable).

136 Once implemented, even a technically reversible policy decision can have irreversible aspects. For example, a government decision to terminate welfare benefits can have substantial immediate and irreversible consequences on the individuals that received such benefits, even if the policy that resulted in the decision is ultimately reversed. Similarly, once initiated, environmental effects (such as oil drilling) flowing from government approval would of course be difficult to reverse.

137 See, e.g., infra text accompanying notes 151-61, 192-208 (outlining variety of costs that accompany subsequent policy changes). 
As discussed below, for many such decisions, the selected policies are similar to those preferred by the new President, including measures necessary to keep agency programs operational. ${ }^{138}$ However, for some decisions, the substantive policy choice presents difficult questions because it is made irrespective of, or sometimes in contrast to, the President-elect's preferences. ${ }^{139}$

The agency also may elect to decide the policy question in an especially durable form, one that will be particularly costly to change or ignore. ${ }^{140}$ An agency might embody a policy decision in a legislative rule rather than in a guidance, as a rule change generally requires notice-and-comment procedures under the Administrative Procedure Act. Legislative rulemaking is probably the most durable such form and hence perhaps the most "entrenched" variety of policy decision. ${ }^{141}$ However, the agency sometimes has no meaningful choice as to the policy's form. A statute may require the use of rulemaking; ${ }^{142}$ alternatively, practical considerations may dictate its use. Standards for benefits applications, for example, tend to be promulgated most effectively and efficiently by rule. ${ }^{143}$

138 See infra text accompanying notes $174-75$. The agency also might be motivated by some other compelling exigency, such as an impending deadline set by statute or court order.

139 See infra text accompanying notes 177-79.

140 See, e.g., Clark, supra note 20, at 154 ("Carter appointees made sure that matters they had been working on for months, sometimes years, were resolved as far as possible. Where final rules could be issued, they were, and where formal proposals could be entered in the [Federal] Register, the Democrats made sure they got on the record.").

141 While rulemaking may be the most durable form of announcing a broadly applicable policy, some decisions in individual transactions, such as the grant of benefits or the settlement of litigation, may be practically irreversible. See infra text accompanying notes 170 73.

142 For a sample of mandatory rulemaking provisions, see, for example, National Forest Management Act $\$ \S 6,11,16$ U.S.C. $\$ \$ 1604,1613$ (2000) (compelling promulgation of land and resource management plans in accordance with statutory criteria and authorizing additional rulemaking as needed); 26 U.S.C. $\$ 9801$ (e)(3) (2000) (requiring Health and Human Service rulemaking concerning appropriate grounds for health insurance denials); Federal Land Policy \& Management Act, 43 U.S.C. \$ 1740 (2000) ("The Secretary, with respect to the public lands, shall promulgate rules and regulations to carry out the purposes of this Act ....").

143 The use of rulemaking may, for example, obviate the need for the agency to litigate the appropriateness of its standard in every enforcement proceeding or case where benefits are sought. See Heckler v. Campbell, 461 U.S. 458, 467 (1983) (upholding agency rulemaking to decide job availability for purposes of disability benefits proceedings rather than case-by-case evaluation). Without such notice-and-comment rulemaking, the agency must "defend and justify its chosen standard in the face of a challenge to that standard." Cmty. Nutrition Inst. v. Young, 818 F.2d 943, 951 (D.C. Cir. 1987) (Starr, J., dissenting in part). Moreover, agency attempts to procure compliance by regulated entities with an informal policy through the use of guidance documents rather than rules sometimes have been struck down for failure to perform notice-and-comment rulemaking. See id. at $946-49$ (in- 
Where the agency is practically or legally compelled to embody its policy in a rule, we might judge an outgoing administration's policy decision to be a "hard case" of policy burrowing or entrenchment because of its timing - the agency chooses to make the policy decision in the last several weeks of the presidential term or specifically in anticipation of the new President's arrival-and because the decision contradicts her likely preferences. A recent Clinton administration example, discussed above, is the rule setting a new drinking water standard for arsenic. ${ }^{144}$

For some policy decisions, the agency may have discretion not only over the policy's timing and content, but also over its form. For instance, for policy questions left by a statute to the discretion of the implementing agency, ${ }^{145}$ the agency often can choose whether to announce publicly its criteria for implementing the program and, if so, in what form. ${ }^{146}$ For example, an agency's use of a policy statement generally only will indicate an "agency's inclination or leaning, not in any way binding on the agency." 147 However, an agency's declaration of implementation criteria through a legislative rule will, of course, bind both itself and regulated entities. ${ }^{148}$ An agency thus may entrench

terpreting FDA "action levels" as binding rules and vacating for failure to use notice-andcomment rulemaking procedures).

144 See supra note 13 and accompanying text. The EPA was subject to a statutory deadline to issue the standard, but that deadline was June 22, 2001. An Act Making Appropriations for the Departments of Veterans Affairs and Housing and Urban Development, and for Sundry Independent Agencies, Boards, Commissions, Corporations, and Offices for the Fiscal Year Ending September 30, 2001, and for Other Purposes, tit. III, Pub. L. No. 106377,114 Stat. 1441, app. a, at 1441 A-41 (2000) ("[T]he Administrator shall promulgate a national primary drinking water regulation for arsenic not later than June 22, 2001.").

145 See supra text accompanying notes 44-46.

146 See supra text accompanying notes 62-71. An agency must, of course, possess the statutory authorization to issue legislative rules, but that authorization often may be very general. See, e.g., 16 U.S.C. $\$ 1613$ (2000) (authorizing Secretary of Agriculture to "prescribe such regulations as he determines necessary and desirable to carry out the provisions of this subchapter"); see also Nat'l Petroleum Refiners Ass'n v. FTC, 482 F.2d 672, 697-98 (D.C. Cir. 1973) (finding general FTC rulemaking authorization sufficiently broad to authorize FTC's issuance of substantive rules of business conduct).

147 Hudson v. Fed. Aviation Admin., 192 F.3d 1031, 1034 (D.C. Cir. 1999); see supra note 70 (providing examples of disclaimer language in agency guidances). Of course, even if a guidance or policy statement is not legally binding on an agency, an agency generally may wish to comply with it in order to maintain its credibility with the public and with the regulated community. Moreover, the D.C. Circuit has suggested that under rare circumstances, it might hold that an agency must comply with a policy statement or guidance. See supra note 71 .

148 It is a well-settled doctrine that an agency must comply with its own rules. See supra text accompanying note 63 (discussing Arizona Grocery doctrine). By comparison, with limited exceptions (for example, declarations of national monuments under the Antiquities Act), executive orders generally do not directly bind parties outside the government. See, e.g., William H. Rodgers, Jr., Executive Orders and Presidential Commands: Presidents Riding to the Rescue of the Environment, 21 J. Land Resources \& Envtl. L. 13, 16 (2001) 
policy both by announcing it late in the term-despite a new President's contrary preferences-and by promulgating it in a relatively durable form, such as a legislative rule. One example is the Clinton administration Forest Service's roadless areas rule, discussed below. ${ }^{149}$ Another is an agency's decision simply to convert a previously flexible policy (perhaps in the form of a guidance) into a rule. ${ }^{150}$

For legislative rulemaking, ${ }^{151}$ both deviation and change costs are relatively high. For example, third parties may be able to challenge agency action as noncompliant with the rule, a strategy generally unavailable if the agency's policy is embodied in a guidance. Further, a new administration wishing to change the policy may face significant costs. Just as the outgoing administration initially did in issuing the rule, the new administration usually must expend resources on a second full-scale APA notice-and-comment rulemaking, ${ }^{152}$ which has evolved into a relatively expensive and time-consuming process. ${ }^{153}$ The now-familiar requirements include the publication of a detailed proposal, often with extensive supporting analyses, and, after public comments have been received, written responses to all significant comments. ${ }^{154}$ For some rules, the procedural burden is substantial. For example, the EPA's 1997 issuance of new final rules revising its

("The presidential executive order is forever constrained by legal doubts since presidents cannot make 'law' in a traditional sense.").

149 See infra text accompanying notes 267-317.

150 See, e.g., infra text accompanying notes $188-89$ (describing Justice Department employee files rule).

151 Cf. Whitman v. Am. Trucking Ass'ns, 531 U.S. 457, 488-89 (2001) (Stevens, J., concurring) (noting tension between Court's insistence that agencies not exercise "legislative power" for nondelegation purposes and legislative character of many agency actions).

152 The APA's rulemaking requirements apply generally to actions taken to amend or rescind a rule. See 5 U.S.C. $\$ 551(5)$ (2000) (defining "rule making"). The agency could avoid the need for a second rulemaking by seeking congressional nullification of the rule through statute, but legislative advocacy itself is time-consuming and unpredictable.

153 While these provisions were originally considered an efficient alternative to an agency's use of formal adjudication to implement policy, some argue that through judicial interpretation and other pressures, rulemaking has become increasingly costly. See, e.g., McGarity, supra note 47 , at 1387.96 (maintaining that requirements for rulemaking process are overly stringent and that rulemaking process accordingly has "ossified"). The APA also provides for formal rulemaking, in which a rule is issued following a trial-type adversary proceeding. However, since the 1960 s, formal rulemaking has been used relatively rarely. See Breyer, supra note 56, at 674-76 (noting that Supreme Court has narrowly construed application of APA's formal rulemaking requirements).

$154 \$ 553$; see, e.g., United States v. Nova Scotia Food Prods. Corp., 568 F.2d 240, 250-53 (2d Cir. 1977) (invalidating FDA regulations for failure to make available sufficient supporting data and to respond to public comments). Responses to comments may be hundreds of pages long. 
national ambient air quality standards for ozone and particulate matter occupied close to 150 pages of fine print in the Federal Register. ${ }^{155}$

On top of investing in a second rulemaking, the agency will face an additional burden if judicial review of the new rule is sought. The relevant review standard of "arbitrary, capricious, an abuse of discretion, or otherwise not in accordance with law,"156 is deferential. However, the mere prospect of judicial review requires the agency to prepare a record on which it can explain its choice of policy persuasively. In some instances, courts have required much more. ${ }^{157}$ In 1983, for example, the Supreme Court applied this standard to strike down the Reagan administration's decision to rescind the Carter administration's requirement of airbags or passive seatbelts for new cars. ${ }^{158}$

Moreover, if judicial review is sought, the time required to respond may be considerable. For example, the Federal Energy Regulatory Commission, faced with addressing a natural gas shortage, reportedly was not able to satisfy judicial concerns regarding its rule revision by the end of the six-year-long shortage. ${ }^{159}$ This is not to say that policy reversals never occur-or that judges never sustain them on judicial review 160 - but simply that the incoming administration can face significant hurdles to reversing policy embodied in a rule. ${ }^{161}$

155 See National Ambient Air Quality Standards for Ozone, 62 Fed. Reg. 38,856 (July 18, 1997) (to be codified at 40 C.F.R. pt. 50); National Ambient Air Quality Standards for Particulate Matter, 62 Fed. Reg. 38,652 (July 18, 1997) (to be codified at 40 C.F.R. pt. 50). 1565 U.S.C. $\$ 706(2)(\mathrm{A})$.

157 See, e.g., Corrosion Proof Fittings v. EPA, 947 F.2d 1.201, 1215-33 (5th Cir. 1991) (examining closely and rejecting agency's reasoning, analysis, and assessment of data).

158 See Motor Vehicle Mfrs. Ass'n. v. State Farm Mut. Auto. Ins. Co., 463 U.S. 29, 46-57 (1983) (finding National Highway Traffic Safety Administration rescission "arbitrary and capricious").

159 See Richard J. Pierce, Jr., The Unintended Effects of Judicial Review of Agency Rules: How Federal Courts Have Contributed to the Electricity Crisis of the 1990s, 43 Admin. L. Rev. 7, 25 (1991) (detailing how lengthy, time-consuming Federal Energy Regulatory Commission rulemaking to address gas shortage and D.C. Circuit order to consider additional alternatives resulted in failure to promulgate effective regulation before shortage had passed).

160 See Good Samaritan Hosp. v. Shalala, 508 U.S. 402, 417 (1993) ("An administrative agency is not disqualified from changing its mind ...." (quoting NLRB v. Iron Workers, 434 U.S. 335, 351 (1978))); cf. Rust v. Sullivan, 500 U.S. 173, 186-87 (1991) (upholding Health and Human Services "gag rule" prohibiting federally funded family projects from informing clients about abortion although noting that "gag rule" was change of position from long-standing earlier policy).

161 Another example is worth mention: An outgoing administration might craft a rule in such a way that an incoming administration could have no justification for changing it except for "political reasons." This seems unlikely, but it might occur in a case in which, for example, the scientific and technical assessment of the rule's costs and benefits are completely settled and certain and the agency is simply reweighing costs and benefits. In that case, the incoming administration's attempts to change the rule might be more likely 
Besides rulemaking, an agency may use other formal and public means of announcing policies in the last several weeks of a presidential administration. An agency may propose a rule containing the policy, without concluding the notice-and-comment process necessary to promulgate a final, binding rule. ${ }^{162}$ Such a proposed rule lacks the force of law, and the administrative costs of abandoning it are minimal. Presidents Reagan, Clinton, and George W. Bush all formally delayed or abandoned, as a group, the proposed rules offered by the agencies under their predecessors. ${ }^{163}$ An agency also may issue a new general policy statement. These types of decisions are inexpensive to issue and, similar to proposed rules, require few administrative costs to abandon, as the revision of a policy statement or guidance is generally not subject to APA procedural requirements. ${ }^{164}$

stymied by judicial review searching for reasoned explanations for the change of position. Cf. Motor Vehicle Mfrs. Ass'n., 463 U.S. at 56 (vacating seatbelts rule for failure to consider alternative developed by previous administration). Possibly due to a lingering sense that agency activities should be oriented to the technical and scientific, see text accompanying notes 90-93 (discussing "transmission belt" conception of administrative law), and possibly due to the prospect that considering political motivations might be deemed "arbitrary and capricious" by the courts or beyond an agency's statutory authority, agencies generally have shied away from overtly justifying their policy decisions with political reasons. Cf. Antonin Scalia, Chairman's Message: Rulemaking as Politics, 34 Admin. L. Rev., at v, xi (1982) (arguing that it would be "refreshing and instructive" if government had characterized its abandonment of seatbelt requirements in the State Farm case as motivated by goal of avoiding excessive paternalism). In such a case, however, the outgoing administration's actions could be criticized as inappropriately preventing the incoming administration from responding to electoral wishes.

162 See, e.g., Fish and Wildlife Service, Endangered and Threatened Wildlife and Plants; Determinations of Whether Designation of Critical Habitat Is Prudent for 20 Plant Species and the Proposed Designations of Critical Habitat for 32 Plant Species from the Island of Molokai, HI, 65 Fed. Reg. 83,158 (proposed Dec. 29, 2000) (to be codified at 50 C.F.R. pt. 17) (proposing critical habitat designations for Hawaiian animal and plant species).

163 See Memorandum for the Heads and Acting Heads of Executive Departments and Agencies, 66 Fed. Reg. 7702 (Jan. 24, 2001) (memorandum from Chief of Staff Andrew Card delaying publication of pending or final regulations until review by Bush appointees); Memorandum for the Heads and Acting Heads of Agencies Described in Section 1(d) of Executive Order 12,291, 58 Fed. Reg. 6074 (Jan. 25, 1993) (memorandum from OMB Director Leon Panetta asking agencies not to publish any proposed or final regulation pending review by Clinton appointee or appointee's delegee); Memorandum Postponing Pending Federal Regulations, 1981 Pub. Papers 63 (Jan. 29, 1981) ("To the extent permitted by law, your agency shall refrain, for 60 days following the date of this memorandum, from promulgating any final rule."). The Bush administration's effort included an attempt to suspend final rules as long as they had not yet taken effect. 66 Fed. Reg. at 7702 . That strategy is currently the subject of legal challenge. See New York v. Abraham, $199 \mathrm{~F}$. Supp. 2d 145, 149-50 (S.D.N.Y. 2002) (reviewing arguments for and against permissibility of changing effective date without additional rulemaking).

164 See 5 U.S.C. $\$ 553$ (b)(3)(A) (2000) (excepting "interpretative rules" and "general statements of policy" from notice-and-comment rulemaking requirements). Moreover, while changes in general policy statements potentially could result in political costs, courts typically decline to review claims that an agency has changed its general policy statements 
Agencies may publicly stake out positions in other ways as well. The agency may prepare a report, send a letter to Congress, declare an "official policy position" in litigation, or make some other form of public declaration regarding its policy preferences. For example, in 1993, the outgoing Bush administration Labor Secretary, Lynn Martin, issued a public memorandum directing the Occupational Safety and Health Administration, within the Department of Labor, to begin developing antismoking regulations for the workplace. ${ }^{165}$ Although the administrative costs of formally changing course are small, these sorts of statements theoretically could, as a legal matter, restrict the agency's latitude to take different positions later. For instance, the Food and Drug Administration's statements in testimony before Congress that it lacked regulatory authority over tobacco impeded the agency's attempt to regulate it years later. ${ }^{166}$

Moreover, as discussed in more detail below, an incoming administration wishing to change course may face political costs, costs to public credibility, or a loss of judicial deference. ${ }^{167}$ By announcing its preferred policy approach, the outgoing administration may be imposing upon the new administration a heavier burden of persuasively explaining its own preferred policy choice. For example, while the Federal Rules of Civil Procedure certainly permit the amendment of a complaint, an agency that changes its legal theory during litigation may lose credibility before the judge and conceivably may be estopped from taking a dramatically different position. ${ }^{168}$ Similarly, as the media observed with regard to the Bush antismoking directive, the

without reason. See, e.g., Hudson v. FAA, 192 F.3d 1031, 1035 (D.C. Cir. 1999) (refusing to review FAA change of general policy statement's approach). But see supra note 71 (citing D.C. Circuit cases requiring notice-and-comment rulemaking for revisions to some interpretive rules).

165 See Frank Swoboda, OSHA Is Told to Proceed on Smoking Rules, Wash. Post, Jan. 15, 1993, at F3.

166 The Fourth Circuit, for example, vacated the FDA's attempt to regulate tobacco through rulemaking under the Food, Drug \& Cosmetic Act in part due to its earlier statements to Congress. See Brown \& Williamson Tobacco Corp. v. FDA, 153 F.3d 155, 168-70 (4th Cir. 1998), aff'd, 529 U.S. 120 (2000). Rather than relying directly on the Fourth Circuit's rationale, the Supreme Court reasoned that through later legislative action, Congress had ratified the FDA's position that it lacked authority. 529 U.S. at 156-57.

167 To the extent a new policy position revises a previous legal interpretation, the new legal interpretation may receive less deference from the courts. See Christensen v. Harris County, 529 U.S. 576, 587 (2000) (applying Skidmore's less deferential "power to persuade" standard to agency interpretation announced in informal opinion letter); Skidmore v. Swift \& Co., 323 U.S. 134, 140 (1944) (holding that deference due to agency interpretations depends in part on interpretation's "consistency").

168 See, e.g., New Hampshire v. Maine, 532 U.S. 742, 750-51 (2001) (setting forth elements of judicial estoppel); Anjelino v. N.Y. Times Co., 200 F.3d 73, 100 (3d Cir. 1999) (using judicial estoppel doctrine to hold plaintiffs to earlier tactical decision to forgo further discovery in order to move litigation forward); Data Gen. Corp. v. Johnson, 78 F.3d 
OSHA action would not bind the Clinton administration, but "likely would force the issue with the Clinton team," 169 putting some burden on the new administration to explain actions diverging from the course set by the previous one.

Finally, agencies may "entrench" policies by resolving individual cases. While these may not, like workplace safety standards, be broad statements of policy, they may be close to irreversible either legally or practically. An agency may settle a litigation by signing a consent decree, issue a permit, issue funds under a grant program (or set the terms of a grant competition), ${ }^{170}$ or recognize an Indian tribe. ${ }^{171}$ Constitutional due process requirements impede the revocation of grants or benefits. ${ }^{172}$ Civil procedure rules similarly make reopening judgments difficult. 173

What might motivate these types of decisions? Why might officials within an agency, the White House, or both wish to decide a policy question formally or make an existing policy more durable given the prospect that the new President might prefer a different outcome?

The subjective motivations for many such actions could be straightforward, without a goal of making policy irrespective of the President-elect's preferences. An agency simply may wish to move along or bring to completion projects that have been underway for years. A legislative rulemaking may take years to complete, especially if the rulemaking will have substantial economic impact. ${ }^{174} \mathrm{~A}$ rulemaking started two years before the close of a presidential administration might naturally come to conclusion near the end of the administration.

In addition, an agency's desire to bring a process to closure may be motivated by efficiency. A new administration's political appoin-

1556, 1565 (Fed. Cir. 1996) (applying doctrine in administrative proceeding). See generally 18 James Wm. Moore et al., Moore's Federal Practice $\$ 134.33$ (6) (3d ed. 2000).

169 Swoboda, supra note 165 .

170 See infra text accompanying note 440 (discussing HUD Notice of Funding Availability).

171 See, e.g., Sean P. Murphy, US: Documents on Indians Backdated; No Prosecution of Former Official, Boston Globe, Mar. 1, 2002, at B2 ("The Inspector General's report portrays the Bureau of Indian Affairs as being in a frenzy to conclude recognition of the two tribes before the Bush administration took over on Jan. 20, $2001 \ldots$. . .").

172 See, e.g., Goldberg v. Kelly, 397 U.S. 254, 261-62 (1970) (holding that constitutional due process requirements apply to welfare benefit revocations).

173 See Fed. R. Civ. P. 60(b).

174 The rule must be developed, and then a proposed rule published to give the public notice of the rulemaking issues and sufficient time to comment-that is, so that the public has "reasonable opportunity to participate in the rulemaking." See, e.g., Fla. Power \& Light Co. v. United States, 846 F.2d 765, 771 (D.C. Cir. 1988) (quoting APA and discussing opportunity to comment). See generally Strauss, supra note 65 , at 1470-72 (considering whether rulemaking delays can be considered "ossification"). 
tees may take months to come up to speed on pending policy issues, and the mere fact that a policy process has been carried over, unfinished, from one administration to another, may delay its completion significantly. Even with respect to a high-visibility policy decision, an outgoing administrator simply may feel that the agency is assisting the incoming administration by taking one more thing off its "to do" list.

Moreover, the end of a presidential term serves as a natural deadline. Administrators are understandably inclined to have tangible achievements to show for their record at the agency. This is especially the case when a legislative rulemaking "delivers" on a promise made by an agency head or by the President. Completion of even a major policy initiative could be primarily motivated by the simple desire to finish work rather than an effort to impede the new administration's efforts to make different policy choices.

These motivations seem far from strategic. Furthermore, for many policies, the incoming President's preferences and those of the outgoing President, embodied in the "entrenched" late-term policy, may be similar. Again, these types of actions seem to raise little concern.

Where there are significant differences from the incoming President's preferences, however, the presence of an irreproachable subjective motivation, even if it could be termed a primary motive, does not justify overlooking those differences. Just because a policy decision is "in the pipeline," its resolution is hardly inevitable. Although the legislative rulemaking process often does have a significant lead time, it is not set in motion to run automatically to conclusion. For example, many rules issued by agencies in "proposed" form are never issued in final form, including rules in which agency employees have invested substantial effort postproposal. ${ }^{175}$ In particular, issuance of a final rule requires the agency to respond to significant public comments, potentially revise the final rule, and send it to the Federal Register for publication, all of which can require a large investment of agency resources. Absent a deadline set by statute or consent decree, and even when a policymaking process has begun years before, a senior administrator or other responsible official generally must decide expressly that issuance of a final rule or other policy is appropriate. ${ }^{176}$

175 See, e.g., infra notes 342-46 and accompanying text (discussing Carter nursing home rule).

176 See, e.g., Declaration of Dr. Willie R. Taylor at paras. 10-12, Kennecott Utah Copper Corp. v. U.S. Dep't of the Interior, No. 93-2223 (D.D.C. declaration executed Dec. 16, 1993) (commenting on dispute within Interior Department regarding potential problems with final natural resource damages assessment rule sent to Office of Federal Register under Bush administration in January 1993). 
For many such rules, the administrators are likely to be fully conscious at the time of whether the rule tends to conform to the President-elect's views or whether the President-elect would choose a different course if given the chance. This was the case, for example, for Health and Human Services nursing home rules under the Carter administration, which the agency attempted to finalize on January 19, 1981;177 EPA wetlands delineation rules under the Bush administration, finalized on January 13, 1993; ${ }^{178}$ and the U.S. Forest Service roadless areas rule issued in the Clinton administration, finalized on January 12,2001 . In all these cases, agency administrators deciding to finalize the rule apparently understood that the policy determination made would be questioned by the President-elect. Similarly, administrators are likely to be well aware of demands by members of Congress in the same party as an incoming President to forgo further work on an issue. ${ }^{179}$

Occasionally, in response to demands from Congress, from the President-elect, or for other reasons, administrators have decided to hold off finalizing a policy decision. ${ }^{180}$ In short, not only may administrators be conscious of the views of the President-elect at the time a

177 See Lardner, supra note 4.

178 After the 1992 presidential election, but before President-elect Clinton took office, several agencies continued to work on revising the federal wetlands delineation rules in a way that would limit the land classifiable as protectible "wetlands." E.g., John $\mathbf{H}$. Cushman, Jr., Quayle, in Last Push for Landowners, Seeks to Relax Wetland Protections, N.Y. Times, Nov. 12, 1992, at A16. This was despite expectations that any such revision was likely to be modified under the Clinton administration. E.g., Bureau of National Affairs, Wetlands: Clinton Expected to Modify Manual Early Next Year, EPA Official Says, Daily Env't Rep. (BNA), Nov. 9, 1992, at AA-1. Ultimately, the Bush administration Environmental Protection Agency and Army Corps of Engineers did jointly finalize a policy selecting a particular wetlands definition. The preferences of the President-elect served as a backdrop to deliberation within the Bush administration, and EPA Administrator Reilly specifically noted that he believed that the final policy "will be accepted by the new administration." D'Vera Cohn, Wetland Redefinition Shelved: EPA Abandons Controversial Rule Change, Wash. Post, Jan. 12, 1993, at A5; see also Tom Kenworthy, Bush Air, Wetlands Proposals Likely to Die, Wash. Post, Dec. 15, 1992, at A10 (reporting resistance of EPA Administrator Reilly to finalizing wetlands proposals).

179 See, e.g., Laurin L. Henry, Presidential Transitions 41-42 (1960) (noting that on "several important [foreign affairs] matters," Taft preferred to "hold steady and leave their disposition to his successor"); supra note 36 (quoting sources on fall 2000 debate over whether Clinton OSHA should finalize ergonomics rule). In the area of foreign affairs, forbearance by the outgoing administration is apparently quite common. See Combs, supra note 34, at 305 (concluding that lame-duck Presidents usually "steer clear" of controversial foreign affairs decisions or seek their successor's concurrence).

180 See, e.g., Kenworthy, supra note 178 (determining that because "[the proposals] would immediately be reversed in the new administration," "it makes little sense" to finalize new proposals (quoting unnamed administration official)); Lardner, supra note 4 (noting that Carter administration delayed decision on ethical guidelines for test-tube babies, deciding that "best course was to pass the issue on to the incoming secretary"). 
rule is finalized, but they generally can choose not to issue the rule and to hold it over until the arrival of the new President and her political appointees.

However, an agency also may choose to proceed with the rulemaking because the official perceives a last chance to make the "right policy," given the known or possibly different policy preferences of the incoming administration. ${ }^{181}$ As one anonymous interviewee paraphrased the motivation of some agency employees proceeding with rulemaking: "The new guys may disagree. I'd rather have my choice."

\section{The Costs of Policy Entrenchment}

The "worst case" of policy entrenchment seems one undertaken with an awareness not only that the President just elected would choose to do something different but that the outgoing administration's actions are likely to hinder the President-elect's implementation of her goals. ${ }^{182}$ Should this conduct be rejected out of hand as undermining our democratic regime and interfering with our ability to hold agencies accountable? As I argue below, not necessarily. Yet, from the President-elect's standpoint, late-term policy entrenchment by the outgoing President is undeniably costly.

Not surprisingly, a President-elect wishing to implement her own policy preferences generally will prefer executive branch agency poli-

181 See Nick Anderson, Business Groups' Lawsuit Targets Ergonomics Rules, L.A. Times, Nov. 14, 2000, at A23 (stating OSHA head justifies rule as needed to protect workers from injury); Cooper \& Schafer, supra note 36 (observing OSHA employees "working round the clock on the final version of its controversial ergonomics rule"); House Democrats Hold News Conference Regarding the Budget (Oct. 31, 2000), 2000 WL 1618495 (quoting statement of Charles Jeffress, Administrator, U.S. Occupational Safety and Health Administration: "[Issuing the ergonomics rule] isn't about politics or [doing something] that some other administration can't change. What this rule is about, is about protecting Americans"); Rosenbaum, supra note 12 (asserting Clinton administration "worked overtime to lock in place a range of rules the Republicans find objectionable"); infra notes 285-93 and accompanying text (suggesting that Forest Service rushed roadless areas rule to conclusion). This does not, of course, answer the question whether the "right policy" is a policy supported by the public, a policy that is in the "public interest" as the administrators see it, or a policy that serves some other interests, perhaps even narrow private interests. See generally Pitkin, supra note 72 , ch. 6 (describing theory of political representation).

182 This conception of the "worst case" would subsume not only those actions taken with the subjective intention of tying the next administration's hands, but those taken with other intentions, such as the desire to bring a policy process to closure coupled with an awareness that the next administration's policy preferences differ and its flexibility on policy likely will be adversely affected. But cf. Beermann, supra note 4, at 22 (suggesting that ergonomics rule was not a problematic "midnight regulation" because "it does not appear that the rule was timed by the agency to avoid the political consequences of promulgating it [during] the administration"). 
cies to be flexible. ${ }^{183}$ The President is likely to wish that executive branch agencies not be tightly constrained by substantive statutory criteria or criteria contained in legally binding rules. ${ }^{184}$ The fewer the legal constraints, the more likely an agency is to be able to respond to the President or to have flexibility to accommodate a change in the President's policy preferences as they are defined in the course of her term. ${ }^{185}$

As discussed above, however, if the outgoing administration has embodied its policy in a rule, for example, the new administration will face both significant change and deviation costs. ${ }^{186}$ Moreover, these change and deviation costs may exceed those faced by the outgoing administration. This is both because of a slightly increased risk of being reversed on appeal ${ }^{187}$ and because the outgoing President may have minimized her own deviation costs by retaining maximum flexibility to address issues case-by-case until the end of her term.

For example, during the Clinton administration, the Justice Department had an informal practice of allowing former employees access to work documents to permit them to respond to inquiries about past activities at the agency and to remove any temptation for departing employees to take workplace documents. In November 2000, just before President-elect Bush took office, Attorney General Janet Reno approved the decision to convert this practice into a more durable legislative rule. ${ }^{188}$ The Department's reported goal for the rule was to limit the new administration's flexibility. In the words of a Justice Department spokesman explaining the reason for issuing the former employee files policy as a rule, "We told [former employees] you could come to the department and have access. But there was a concern

183 See Moe, supra note 107, at 280 (observing that Presidents want "authority in the hands of their own political appointees").

184 Id. at 280-81 ("Presidents want agencies to have discretion, flexibility, and the capacity to take direction. They do not want agencies to be hamstrung by rules and regulations-unless, of course, they are presidential rules and regulations ....").

185 See id.; cf. Mashaw, supra note 50, at 152 (arguing that presidential control under vague statutes can result in greater agency flexibility and responsiveness to changing electoral preferences). On the other hand, Presidents sometimes may desire to use rules as a means of ensuring that the conduct of low-level employees conforms to presidential wishes. See Moe, supra note 107, at 280-81.

186 See supra notes 151-61 and accompanying text.

187 See supra notes 151-61 and accompanying text. Of course, the incoming President and her political appointees never write on a completely blank slate, but their latitude to make a particular policy decision may be affected by a visible and decisive action on that same issue by the outgoing administration.

188 Access to Documents by Former Employees of the Department, 65 Fed. Reg. 68,891 (Nov. 15, 2000) (to be codified at 28 C.F.R. pt. 16). 
that in the future the department might not be as generous, so that's why this rule was put in place now."189

In another example, the EPA acted to clarify a statutory ambiguity under the Clean Water Act late in 2000, shortly before the arrival of President George W. Bush. A Clean Water Act section-which required the EPA to prepare a document setting the amount of tolerable pollutants for a particular body of water (a so-called "total maximum daily load" or TMDL) if the state in which the body of water was located submitted an inadequate TMDL - was ambiguous on EPA's obligations in the event the state completely failed to submit a TMDL. The EPA had for years-and up through the end of the Clinton administration-reserved the right to argue that it had no legal obligation to set pollution levels if the state completely failed to do so and that any preparation of a TMDL under such circumstances essentially would be voluntary and, implicitly, could be ad hoc. ${ }^{190}$ Late in the Clinton administration, however, the EPA issued a rule that, among other things, conceded that the EPA was obliged, under the terms of the statute, to prepare a TMDL if the state failed to do so. ${ }^{191}$

As noted earlier, compared with rulemaking, some other forms of policy entrenchment, such as the issuance of proposed rules or general policy statements, typically will come with lower change and deviation costs for the new administration. ${ }^{192}$ Others, however, such as grant awards or litigation settlements, may have such high change and deviation costs as to be close to irreversible. ${ }^{193}$

189 Daniel Seligson, Reno Approves Limited Access for Former DOJ Employees, Nov. 17, 2000, at http://www.planetgov.com (last visited Nov. 28, 2000) (emphasis added) (quoting official of Justice Department) (on file with the New York University Law Review).

190 E.g., Kingman Park Civic Ass'n v. EPA, 84 F. Supp. 2d 1, 5 (D.D.C. 1999) (describing EPA's arguments that it was not obligated to prepare total maximum daily load (TMDL)).

191 See Revisions to the Water Quality Planning and Management Regulation and Revisions to the National Pollutant Discharge Elimination System Program in Support of Revisions to the Water Quality Planning and Management Regulation, 65 Fed. Reg. 43,586, 43,669 (July 13,2000 ) (to be codified at 40 C.F.R. $\$ 130.35$ ). That rule's effective date was repeatedly delayed by the EPA under the Bush administration; it never went into effect. At the end of 2002, the agency proposed to withdraw the rule altogether, and, as this Article went to press, a final rule was issued accomplishing the withdrawal. See Withdrawal of Revisions to the Water Quality Planning and Management Regulation and Revisions to the National Pollutant Discharge Elimination System Program in Support of Revisions to the Water Quality Planning and Management Regulation, 68 Fed. Reg. 13,608 (Mar. 19, 2003) (to be codified at 40 C.F.R. pts. 9, 122, 123, 124, 130) (noting that 2000 rule never became effective); Douglas Jehl, E.P.A. Delays Further Rules of Clinton Era; Stalls Enforcement of Waterway Plan, N.Y. Times, July 17, 2001, at A17.

192 See supra notes 162-64 and accompanying text (noting that general policy statements are typically subject to few procedural requirements and not binding on agency).

193 E.g., infra notes 440-44 and accompanying text. In Michigan, an environmental group alleged in fall 2002 that the Michigan Department of Environmental Quality was rushing to conclude an environmental consent order favorable to Dow Chemical, with 
Besides imposing change costs and deviation costs upon a new administration that wishes to take policy in a different direction, policy entrenchment by an outgoing administration also may impose political costs, including costs upon the new administration's ability to pursue the President-elect's preferred policy agenda.

The first category of political costs-costs accompanying a change from the policy set by the outgoing administration-tends to be the source of the charge that an outgoing administration has laid a "booby trap" for the incoming President. ${ }^{194}$ For example, the Bush administration's suspension of the Clinton administration rule setting acceptable levels of arsenic in drinking water at ten parts per million led to substantial public criticism. The actions on the arsenic standard became a "symbol ... [of the Bush] administration's callous attitude toward the environment." 195

Of course, a presidential administration always can incur political costs for a policy decision that the electorate finds unpopular. However, the presence of the outgoing administration's late-term decision as a foil potentially can increase these political costs. Suppose the new administration's policy preferences would have been served by retaining the status quo prior to the outgoing administration's decision. Absent the outgoing administration's decision, the new administration could have accomplished its goals through simple inaction. The legal and political costs accompanying agency inaction are likely to be

sharply reduced standards for a dioxin cleanup, in recognition of the impending conclusion of Governor Engler's term. See, e.g., E-mail from Robert Reichel, Assistant Attorney General, to Art Nash, Michigan Department of Environmental Quality (Oct. 11, 2002), in An E-mail from an Assistant Attorney General to Nash Dated October 11 That Warns the DEQ Deputy That the Agreement He Is Seeking to Negotiate Is Illegal, Ecology Center News, at http://www.ecocenter.org/releases/october11_2002_agmemo.shtml (last visited Apr. 8, 2003) ("Dow's own counsel has told us that ... Dow is concerned that depending upon the results of the November gubernatorial election, future DEQ management may not be as receptive as the present administration to Dow's . . . arguments."). Ultimately, after environmental groups filed a lawsuit and publicly charged the administration with a last-minute "sweetheart deal," negotiations fell apart just before Governor Engler left office. See Eric Pianin, Michigan and Dow Drop Dioxin Pact: State Backs Away from Plan to Relax Pollution Standards, Wash. Post, Dec. 31, 2002, at A2.

194 See, e.g., Ronald Brownstein, Bush Steps Lightly with His Agenda After Triggering Clinton Land Mines, L.A. Times, Apr. 23, 2001, at A1 (stating that policy controversies are almost as if "Clinton sowed land mines all across the path of his successor's first 100 days"); Katharine Q. Seelye, No Affinity for Trees, but a Nature Crusader Nonetheless, N.Y. Times, July 2, 2001, at A15 (noting that friends "credit Mr. Podesta with ... helping to set political booby traps for President Bush with last-minute environmental rules").

195 Douglas Jehl, House Demanding Strict Guidelines on Arsenic Levels; Rejects Bush Approach; 19 in G.O.P. Join to Preserve Clinton Rule on Tap Water-White House Objects, N.Y. Times, July 28, 2001, at A1. 
lower. ${ }^{196}$ In the arsenic standards case, had the Clinton administration not acted, a Bush administration decision to leave arsenic standards at the same level might well have gone unnoticed since raising the issue would have required the electorate to pay attention to and to evaluate the scientific assessment of arsenic's risks. ${ }^{197}$

By comparison with completed policies, incoming Presidents often have abandoned incomplete agency decision processes without incurring significant political cost. An incoming President might, for example, never finalize a rule that was only proposed by the previous administration. Opting not to follow through with a proposed change, rather than taking the more proactive step of reversing a final policy enacted by a previous administration, may create less of a focal point for controversy.

As discussed below, to the extent the public learns the outgoing administration's view of the appropriate policy choice, especially when supported by an administrative record, it gains significant additional information about the feasibility and defensibility of policy alternatives. That can enhance public discourse. ${ }^{198}$ From the standpoint of the President-elect, however, the presence of such a policy alternative could permit some to argue-whether fairly or unfairly-that the outgoing administration's action on an issue such as arsenic sets the correct policy baseline and that the new administration's action is a "rollback," that should be accompanied by political costs. ${ }^{199}$

196 See Calabresi, supra note 79, at 47 ("The cost to the public of sticking with the old is rarely clearly shown ...."); cf. Heckler v. Chaney, 470 U.S. 821 (1985) (declining to review agency refusal to enforce statute).

197 Arguably, years of Clinton administration inaction on the arsenic issue went largely unnoticed. See David Schoenbrod, Fishing for Cancer 47 (N.Y. Law Sch., Public Law and Legal Theory Research Paper Series No. 02/03-18, 2002), http://ssrn.com/abstract_id= 376420 (noting environmentalist outcry at Bush administration arsenic decision "even though they had uttered scarcely a peep during the eight years the Clinton administration temporized on this issue").

198 See infra notes 322-50 and accompanying text.

199 It is, of course, possible that the outgoing administration might be attempting to exploit irrational elements in public opinion, just as commentators have sometimes alleged regarding presidential campaigns. See, e.g., Robert W. Bennett, Counter-Conversationalism and the Sense of Difficulty, 95 Nw. U. L. Rev. 845, 872 (2001) (noting that campaigns may try to identify issues on which voters will agree with candidate, even if issues are "simplistic" or "petty"). For example, perhaps one might argue that the arsenic rule is ridiculously overprotective, but that the mere issuance of the rule will make any contrary Bush administration action look overprotective. In view of the record required to sustain a rulemaking, however, not to mention the time and resources involved, it seems unlikely that an outgoing administration's sole motivation would be to create a political "booby trap" for the incoming administration. See infra text accompanying notes 364-69 (examining administration's likely selection of issues for rulemaking). This might be a greater concern with regard to actions requiring less consideration and less documentation. See, e.g., 
In addition, depending on her selection of policy, the outgoing President, rather than the new President, may get a first-mover advantage. The new President may generally use administrative authorities to reverse an outgoing administration's action. However, to the extent the new President were to desire a legislative modification of the outgoing President's policy, ${ }^{200}$ the presence of cloture and veto override procedures in Congress, which effectively require supermajority support for the new proposal, would make that more difficult.201

Policy entrenchment also can impose political costs on a new President by "crowding" the public agenda. A new President, of course, arrives in Washington with the approval (if not the "mandate") of the national electorate for the President's platform. A new presidency typically "changes agendas all over town as it highlights its conceptions of problems and its proposals." 202 The President is in a position not only to develop new policy alternatives, but to put them on the national agenda, whether by initiating administrative action or making a proposal to Congress. ${ }^{203}$ The President regularly sends large "legislative packages" to Congress, and the contents of these packages very often influence the congressional agenda. Consequently, the President sometimes has been called the nation's "Chief Legislator." 204 Some have argued that the first few months of the administration are a critical time-perhaps even a "honeymoon period"-for the President to establish herself as a national leader and to make progress on her policy agenda. ${ }^{205}$

supra notes 2-3 and accompanying text (describing probable booby trap involving presidential limousine license plates).

200 See, e.g., supra note 135 and accompanying text (describing Congress's use of Congressional Review Act to repeal Clinton administration ergonomics rule); see also infra text accompanying notes 366-69 (describing ergonomics rule repeal).

201 See Keith Krehbiel, Pivotal Politics: A Theory of U.S. Lawmaking 38 (1998) ("When status quo policies are moderate, cloture and veto procedures prohibit further convergence to centrally located policies."); see also William N. Eskridge, Jr. et al., Cases and Materials on Legislation: Statutes and the Creation of Public Policy 75-78 (3d ed. 2001) (discussing Article I, $\$ 7$ game); Krehbiel, supra, at 46-47 (arguing that presidential success with legislative proposals immediately after inauguration largely attributable to policies out of "equilibrium" with congressional preferences); supra note 135 and accompanying text (noting single use, since its adoption in 1995, of Congressional Review Act to overturn agency rule).

202 John W. Kingdon, Agendas, Alternatives, and Public Policies 208 (1984).

203 See generally Waterman, supra note 108, at 4-5 (detailing role of modern President as strong formulator of policy).

204 See Clinton Rossiter, The American Presidency 28 (2d ed. 1960); Steven G. Calabresi \& Joan L. Larsen, One Person, One Office: Separation of Powers or Separation of Personnel?, 79 Cornell L. Rev. 1045, 1089 n.231 (1994).

205 See, e.g., Paul C. Light, The President's Agenda: Domestic Policy Choice from Kennedy to Clinton 43 (3d ed. 1999) (stating that administration's "first year presents the greatest opportunity for programmatic impact"); Steven G. Calabresi, Advice to the Next 
Where a previous President has taken a significant entrenching step, however, it may compel the new administration to confront the issue, thereby occupying space on the presidential agenda. ${ }^{206}$ The new President may feel forced to expend political capital reacting to earlier policy decisions, either because the President wishes to return flexibility to administrative agency programs or because the President wishes to select a different policy direction. This can displace the new President's preferred agenda items. The cost to the President's agenda may be especially high because the President may have to respond to earlier decisions at the beginning of the presidential term when she feels increased pressure to demonstrate leadership and momentum in accomplishing her policies. Moreover, the cost is, of course, borne not only by the President, but potentially by voters whose preferences would have been served by the new President's platform. 207

For example, President George W. Bush has had to expend significant political capital on justifying his departures from and changes of Clinton administration environmental policies. In the first years of the Bush administration, that topic occupied hundreds of newspaper editorial pages and accounted for numerous front-page articles in newspapers with national readership, potentially crowding out coverage of President Bush's preferred policy initiatives. ${ }^{208}$

Conservative President of the United States, 24 Harv. J.L. \& Pub. Pol'y 369, 371 (2001) ("Successful Presidents must have a successful first 100 days or at least a successful first 8 months."); John Frendreis et al., Predicting Legislative Output in the First One-Hundred Days, 1897-1995, 54 Pol. Res. Q. 853, 854 (2001) ("Political capital for any incumbent is greatest following his electoral victory because public opinion rallies behind presidential leadership during the 'honeymoon' period, after which long-term 'decay' in popular support begins."); see also Krehbiel, supra note 201, at 46 (attributing "honeymoon period" burst of legislative activity to presence of policies out of equilibrium with majoritarian political preferences).

206 See Morrow, supra note 4, at 3 ("[O]utgoing administrations wind up setting the agenda for the incoming administrations." (paraphrasing Senior Federal Circuit Judge Jay Plager)).

207 On the other hand, to the extent one accepts Krehbiel's view that a new President can obtain legislative changes because of the significant number of policies out of the equilibrium defined by the cloture and veto override rules, a delay in the President's ability to act past the first year might make little difference in her ability to obtain legislative change. See Krehbiel, supra note 201, at 46 (discussing view that new Presidents succeed with legislative change because of number of out-of-equilibrium policy points ripe for correction).

208 For a partial example, a LEXIS/NEXIS search of newspaper editorials and op-eds during 2001 mentioning "environment" (or "environmental"), "policy," "Bush," and "Clinton," yielded over 900 stories. In the New York Times, Washington Post, and Los Angeles Times alone there were over one hundred such stories. 


\section{B. Personnel Burrowing and Its Costs}

\section{Characteristic Personnel Entrenchment Actions}

In addition to entrenching policy, outgoing administrations may entrench people. A so-called "political" appointee may legally "burrow" into an agency by moving to a different career civil service position, very often one with significant policymaking responsibility. ${ }^{209}$ Typically, over a hundred political appointees have stayed on-in career civil service positions-after the close of the administration in which they were appointed. In the transition from George H.W. Bush to Bill Clinton, 159 officials moved from political appointments to career civil service appointments, some with substantial policymaking authority. ${ }^{210}$ And in the transition from Clinton to George W. Bush, over one hundred individuals moved from political appointments to career civil service appointments. ${ }^{211}$ In part because these types of hiring decisions have relatively high visibility, however, they generally will not be the main mechanism by which a departing administration will leave its imprint on an agency's personnel.

Instead, departing political appointees are more likely to make significant promotion decisions, including choosing career civil servants to direct particular programs or offices or to hold other senior positions. In addition, an agency also might fill, from the outside, important career civil service positions or might hire civil servants in significant numbers before the close of an administration. For example, at the end of George H.W. Bush's presidency, the Department of Energy selected a new director of its Office of Procurement, Assistance, and Program Management, responsible for managing billions of dollars worth of government contracts. The new director did not take

209 An agency must, however, make a special report of such a civil service hire to the Office of Personnel Management. E.g., Recruitment and Selection for Initial SES Career Appointment Be Achieved from the Brightest and Most Diverse Pool Possible, 5 C.F.R. $\$ 317.501$ (2002) (allowing political appointee to receive career Senior Executive Service appointment subject to merit staffing review of Office of Personnel Management); Memorandum from Janice $R$. LaChance, Director, Office of Personnel Management, to Heads of Departments and Agencies 1, 3 (Feb. 18, 2000), http://www.opm.gov/ovrsight/trnsltr.pdf [hereinafter LaChance Memorandum] (regarding "Limitations on Appointments and Awards During the Election Period").

210 See GAO, 1995 Personnel Practices, supra note 27, at 5 (noting that in last two years of Bush administration, 159 individuals moved from noncareer positions to career positions and that 110 individuals moved from noncareer positions to career civil service positions in last two years of Reagan administration); id. at 6 (describing types of positions).

211 See GAO, 1998-2001 Personnel Practices, supra note 27, at 2 (reporting that one hundred former political appointees converted to career positions from October 1, 1998, through April 30, 2001). 
office until the last full day of the Bush administration. ${ }^{212}$ The hiring decision inspired congressional criticism. ${ }^{213}$ Congressional Democrats complained bitterly that the new Energy Secretary should be permitted to "put her own organization in place." 214

Also during the outgoing George H.W. Bush administration, public concern was expressed regarding the November 1992 request of an Interior Department political official, apparently at the direction of the Interior Department Secretary, that the Department's agency chiefs and personnel officers provide him with a list of unadvertised job vacancies. ${ }^{215}$ In the final quarter of the Clinton administration, the Department of Housing and Urban Development (HUD) announced that it would hire nine hundred civil servants - ten percent of HUD's entire workforce. ${ }^{216}$ After some controversy over its potential impact on workforce composition under the Bush administration, the hiring project was shelved, though it was unclear that it was ever motivated by anything more than addressing the employment vacancies created by normal attrition. ${ }^{217}$

Further, agencies sometimes adopt reorganization plans-significantly reducing the size of particular staffs or offices or changing an office's organizational structure-shortly before a new President is inaugurated. For example, the outgoing George H.W. Bush administration decided to eliminate a 141-person office of the Army Corps of Engineers in Buffalo three days after the election. ${ }^{218}$ During the same transition, a Senate subcommittee identified a "dozen agency reorganizations" that they felt might raise concern for the incoming Clinton

212 See Thomas W. Lippman, 'Eleventh-Hour' Reorganization at Energy Arouses Dingell's Ire, Wash. Post, Jan. 17, 1993, at A40.

213 See id. (detailing letter written by Congressman Dingell to outgoing Energy Secretary James D. Watkins expressing his "grave concern" about changes in Energy Department prior to Secretary's departure).

214 Id.

215 See Stephen Barr, OPM Team at Interior Begins Probe of Hiring, Wash. Post, Dec. 15, 1992, at A21; Stephen Barr \& Ann Devroy, "Burrowing In" Seen Setting a New Standard, Wash. Post, Nov. 20, 1992, at A23 (reporting that Secretary Lujan wrote memo asking political official, Assistant Secretary for Policy John Schrote, to assume responsibility for all hiring for certain positions and that memo could be read to imply that Interior was trying to remove obstacles to political appointees obtaining career civil service positions).

216 See Kenneth J. Cooper, HUD Jobs Plan Trips Hill Alarm; Congressman Probes 'Timing' of 900-Position Hiring Project, Wash. Post, Oct. 31, 2000, at A21.

217 Id; see infra note 220.

218 See Douglas Turner, Corps of Engineers Reorganization on Hold: Federal Plan Would Drop 141 Positions from Buffalo District Office, Buffalo News, Jan. 27, 1993, 1993 WL 6069871 . 
administration, including in the Departments of Defense, Transportation, Labor, and Health and Human Services. ${ }^{219}$

What motivates these personnel decisions? As with policy burrowing, some actions seem justified by benign concerns. Budgetary concerns might drive office shrinking. Similarly, vacancy filling might be needed so that agency work can progress; in the words of one interviewee, to ensure that an agency that is potentially "headless and directionless can still do a pretty good job." Processing a civil service appointment can take significant time, especially considering the months often needed to perform security checks. 220

However, at least some personnel decisions appear motivated to entrench or reduce an institutional commitment to a particular program. As Richard Waterman has observed, "The manner in which an agency or department is organized can have a major impact on policy outcomes."221 For example, the Bush administration cuts in the Army Corps' Buffalo office discussed above were perceived by some as reducing the agency's ability to help administer the Superfund hazardous waste cleanup program.222 And more recently, in the State of Michigan, an employee of the Department of Environmental Quality alleged that a late-term reorganization of the Department by outgoing Governor Engler in fall 2002, which reportedly resulted in geologists with oil and gas expertise administering wetlands programs and biologists running oil and gas programs, was intended to "set back the effectiveness" of the agency for many years. ${ }^{223}$

Moreover, outgoing political appointees may wish to hire or promote employees within the agency whose view of the public interest is consistent with the policy goals of the outgoing administration. For example, an agency official serving within the EPA under President Clinton might perceive that civil servants selected by Reagan and

219 Stephen Barr, Senior Executives Fault Transfers; Group Seeks Halt to Reassignments of Top Managers During Transition, Wash. Post, Dec. 10, 1992, at A19 (relaying that congressional subcommittee provided GAO with "tentative list of a dozen agency reorganizations that the subcommittee would like reviewed to ensure that they do not pose special problems for the Clinton Administration").

220 This was likely the motivation behind HUD's "Project Hire." Despite initial congressional inquiries into the hiring process, Congress pressed no investigation. For example, one concerned congressional office was reassured by the agency's explanation that many, if not most, hires planned under Project Hire would not be finalized until after inauguration. Telephone Interview with Doug Kantor, former Deputy Chief of Staff for Programs, Department of Housing and Urban Development (Dec. 26, 2002).

221 Waterman, supra note 108 , at 40 .

222 See Turner, supra note 218 (mentioning Senator Daniel Patrick Moynihan's suggestion that cuts in Buffalo office might be unnecessary "if the corps was more aggressive about its new role in helping to administer the Superfund toxic-waste cleanup program").

223 DEQ Reorganization: An Employee Speaks Out, Mich. Envtl. Rep., Oct. 2002, at 3, http://www.mecprotects.org/MER/OCT02/deqreorg.html. 
Bush were "all around us" and wish to "green up" the civil service staff of the agency. While achieving this goal might not be easy due to the procedural requirements for civil service hiring, these types of goals also may inform promotion decisions.

Individuals in the career service seen as particularly competent, "impressive," as well as committed to policies or possessing views important to the outgoing administration, apparently are prime candidates for promotion. A political appointee's selection of the head of a policymaking office, even a temporary head, often represents the appointee's effort to institutionalize an agency commitment to preferred programs. A departing political appointee might look for a person "after his own heart" ideologically to direct an office. Or, a "beancounter" might be promoted to run a new program to give the departing political appointee some assurance that the new program will actually be implemented. ${ }^{224}$ The commitment by some federal agencies, including, reportedly, the Treasury Department, to forgo filling any civil service positions between a presidential election and the new President's inauguration implicitly confirms that outgoing agency administrators that do hire or promote late in the term are subjectively aware of the potential costs to the President-elect.

Why might an individual accept such an appointment late in a presidential administration? The employee that is hired or promoted to a senior position may wish to remain involved in government policymaking. For example, as one senior policy official that stayed from the Carter administration into the Reagan administration commented, "I didn't want to just leave the government to the Republicans." In addition to serving the public interest as she sees it, such an appointment will serve the employee's personal interests. A civil service appointment may represent a job with reasonable security, decent benefits, and, if it includes policymaking work, may be seen as intrinsically interesting and worthwhile..$^{225}$

224 Career civil servants closely aligned with the outgoing administration might, to reward them for their loyalty, be moved to more secure positions less likely to be targeted by the incoming administration. These positions might not be ones with substantial policymaking authority, but they might ensure that the employee continues to receive a secure salary and benefits.

225 See Mike Causey, Eyes on Appointees, Wash. Post, Nov. 5, 1992, at C2 (observing desire of political appointees to remain in government in order to qualify for pensions); Mike Causey, Who Needs This Boss?, Wash. Post, Dec. 21, 1984, at B2 [hereinafter Causey, Who Needs This Boss?] ("Many of us are in the federal government because we think this is an exciting place to be, and we are making a contribution that we couldn't make in the private sector. Pay and benefits have been good, not the best, but good." (quoting unnamed Agriculture Department scientist)). 
These reasons are both self-interested and publicly interested. By comparison, the likely prediction of public choice theorists that an employee would stay on into the next administration in order to distribute even more rents to interest groups (and increase the ultimate chances of a high-paying private sector job) seems conceivable, but unlikely. 226 Moreover, David Spence and Frank Cross have argued persuasively that there is little or no empirical evidence to support the idea that financial self-interest determines many choices made by individual agency employees: "[S]trongly held policy values and professional norms are at least as likely as any resource implications to guide [bureaucratic] decisions."227

\section{The Costs of Personnel Entrenchment}

Some hiring practices might be characterized simply as ensuring that the government keeps operating. Substantial numbers of vacancies, if left unaddressed, obviously could impair agency functions of regulating, enforcing the law, or processing benefits or citizenship applications.

The facts, however, suggest that at least some hiring and promotion decisions fit the "worst case" scenario. A departing administration might embed people with particular ideological or programmatic commitments, with awareness of-but not regard for-the preferences of the President-elect. As with policy burrowing, agencies that

226 See, e.g., Jean-Jacques Laffont \& Jean Tirole, A Theory of Incentives in Procurement and Regulation 476 (1994) (explaining possible influence on public decisionmakers of "hoped-for future employment for commissioners and agency staff with the regulated firms or their law firms or with public-interest law firms"); Hugh Heclo, The In-and-Outer System: A Critical Assessment, 103 Pol. Sci. Q. 37, 53 (1988) (describing incentives for FCC commissioners to "be cozy with" industry to protect chances of future industry employment); see also Beermann, supra note 4 , at 21 (referring to agency officials' concern regarding posttransition employment).

Generally, private employers might find unattractive the prospect of hiring someone who has actively subverted her organization. But even if this explanation of agency employee motivation is plausible, additional increments of government service do not seem to be rewarded with a greater likelihood of private sector employment. Instead, the conventional wisdom is that the longer one remains in government, the more one is likely to be viewed as a "lifer" and neither strongly interested in, nor suited for, private sector employment. See, e.g., Croley, Public Interested Regulation, supra note 130, at 29 ("Over time, then, those who remain with an agency are those who tend to believe in its mission and who reap personal satisfaction from a sense that public service truly serves the public."); Causey, Who Needs This Boss?, supra note 225 (quoting scientist). See generally Farina, supra note 104, at 115 (remarking that public choice scholars concede that "administrators may be motivated by ideology or their own sense of what constitutes the public good").

227 Spence \& Cross, supra note 72, at 117. 
burrow personnel are likely to be cognizant of the costs to the new President's ability to choose her own preferred personnel. ${ }^{228}$

Those costs potentially could be significant. The President-elect will, of course, want civil servants who are responsive, accountable, and who will exert maximum energy and intellect on behalf of the new President's policy agenda. Directly ensuring that civil servants function this way is difficult, however. Civil servants exercise discretion over a host of major and minor decisions. For example, the individual forest supervisor at the United States Forest Service may have considerable discretion to grant (or deny) access to particular forest lands, while a line attorney at the Department of Justice will have responsibility for developing and framing legal arguments in a brief.

Other civil servants may help identify issues for the agency's agenda-public problems that could be effectively addressed by government action, whether that is addressing flaking lead paint in public housing or encouraging the development of new automobile technologies. They also might recognize means of communicating and effectuating the policy: preparing and transmitting a bill to Congress, issuing regulatory standards, or filing an amicus brief in litigation. As a practical matter, political appointees and their delegatees are unlikely to be able to monitor all such decisions closely.229

Such decisions cannot be carried out solely by political appointees, primarily because the vast majority of federal employees are competitively chosen civil servants. ${ }^{230}$ An obvious substitute for close monitoring is to hire and rely upon civil servants who are loyal either to the President personally or to her preferred policy agenda.231 Even though career civil service hiring is, as a formal matter, competitive and merit-based, the reality is that political concerns often factor into those choices. For example, political appointees may review significant civil service hiring decisions before a job offer is made. ${ }^{232}$

228 Further, an outgoing administration deliberately could reorganize an agency to be less effective under the next President. See supra text accompanying notes 222-23. An incoming administration might suffer efficiency losses from the outgoing administration's relocating of loyal career civil servants to new, more secure positions. See Barr, supra note 219.

229 See, e.g., Seidenfeld, supra note 44, at 477-78 (noting difficulty of detecting nuances in agency staff analyses).

230 See, e.g., U.S. Office of Pers. Mgmt., OWI-02-02, The Fact Book 8, 15, 76-77 (2002) (stating that approximately twenty-three percent of federal civilian labor force, including legislative employees, is in political or "excepted" service).

231 See, e.g., Seidenfeld, supra note 46, at 28 (arguing that President's successful hiring of "individuals who share his basic values" will reduce his need to monitor every agency decision).

232 See Heclo, supra note 226 , at 53 (observing role that politics can play in civil service hiring through political "clearance" and informal hiring "networks"). 
Since the creation of the competitive civil service, an arriving President always has faced some prospect of an unresponsive bureaucracy. ${ }^{233}$ Since the early 1900 s, when the civil service was reformed to eliminate the "spoils system" and to create a civil service selected on the basis of merit considerations, ${ }^{234}$ political appointees have faced a potentially uneasy relationship with the career civil servants already in the bureaucracy. ${ }^{235}$ The concerns political appointees may have with civil servants hired in earlier administrations who are unresponsive, oppositional, or ineffective are significant and amply detailed elsewhere. ${ }^{236}$ Very briefly, of the civil servants present in agencies when a new administration arrives, some inevitably may feel obligated to act in tension with the wishes of political appointees because of a desire to protect the agency or a particular program "at all costs." 237

Personnel burrowing seems to increase the prospect that a new President will face a resistant-even subversive-bureaucracy. Outgoing political appointees may select or promote civil servants in part because they have an especial commitment to a particular vision of an agency program, to particular allegiances, or to a set of political ideas. Such individuals may be less responsive to the President than employees selected by the President or her political appointees in a process that takes into account personal loyalty or policy preferences. Consequently, the presence of such individuals in the new administration, especially those in senior or policymaking positions, seems to present a larger risk of subversion of the President's policy agenda than posed by the normal group of career civil service "holdovers."

Subversion might be passive. A civil servant might let an assignment fall between the cracks or simply fail to perform a disliked task promptly. ${ }^{238}$ A civil servant might be compliant, but fail to be energetic or entrepreneurial on behalf of the new President's agenda. She

233 Cf. supra text accompanying note 1.

234 See generally Stephen Skowronek, Building a New American State: The Expansion of National Administrative Capacities, 1877-1920, at 178-210 (1982) (describing efforts of Theodore Roosevelt, Taft, Wilson, and Harding to eliminate "spoils system").

235 See, e.g., Hugh Heclo, A Government of Strangers: Executive Politics in Washington 1 (1977) ("Every new administration gives fresh impetus to an age-old struggle ... between political leadership and bureaucratic power.").

236 See, e.g., id. at 204-05 (characterizing bureaucratic inertia as compound of "opponents," "reluctants," "critics," and "forgotten").

237 Id. at 224.

238 See, e.g., Robert Maranto, Political Appointees, Career Executives, and Presidential Transitions 21 (prepared for delivery at 2001 Annual Meeting of the American Political Science Association, San Francisco, Aug. 30-Sept. 2, 2001), http://pro.harvard.edu/papers/ 023/023002MarantoRob.pdf (last visited Apr. 8, 2003) (explaining that many political appointees encountered passive subversion, though most perceived such incidents as "isolated"). This argument is related to the argument that having a tenured civil service can result in inefficiency. See Thomas W. Merrill, High-Level, "Tenured" Lawyers, Law \& 
could passively subvert the President and her political appointees' goals by not reporting opportunities to advocate preferred policies. Such lost opportunities might include, for example, the presence of a relevant pending legislative proposal on which the agency's views could be transmitted to Congress. The person might forgo identifying such an opportunity because she expects to disagree with the President's views and the likely outcome in Congress or simply in order to maximize leisure time and "hedge against unforeseen future demands on [her] time." 239 Similarly, the civil servant might fail to enthusiastically prepare a political appointee to testify in front of Congress, which might result in the appointee making a mediocre showing or even being embarrassed. ${ }^{240}$ Again, these types of subversion are likely to be difficult for a political appointee to detect. ${ }^{241}$ More extensive monitoring to address potential subversion would, of course, tend to divert both time and resources from other agency activities.

Subversion could be more active as well. From the standpoint of the President or her political appointees, a holdover conceivably could throw a "wrench in the works" by leaking information to discredit a person or agency. ${ }^{242}$ During the Reagan, Clinton, and Bush administrations, Department of the Interior civil servants hired during earlier administrations reportedly have provided documents regarding the Arctic National Wildlife Refuge to interested congressional staff despite the wishes of agency supervisors. ${ }^{243}$ During the present Bush

Contemp. Probs., Spring 1998, at 83, 104 ("[A]ny system of tenure creates inefficiencies in the form of the increased opportunities for shirking.").

239 Seidenfeld, supra note 44 , at 476 . Moreover, to the extent the civil servants are new hires, the outgoing administration itself will not bear the cost of a poor-quality hire. See generally Merrill, supra note 238, at 85 (asserting that "[h]igh-level tenured lawyers are often regarded with suspicion" by new President and his appointees and that "they cannot be removed ... even if they are suspected of hostility toward the policies of the incoming administration"); cf. Waterman, supra note 108, at 33 (noting that even presidential appointees may not be fully responsive).

240 See, e.g., Heclo, supra note 235 , at $188-89$.

241 Cf. Strauss, supra note 97, at 590 ("[T] he layer over which the President enjoys direct control of personnel is very thin.").

242 See, e.g. Heclo, supra note 235, at 226-27 (listing examples, including agency employee's drafting of legislative rider to nullify changes sought by agency's political appointees). Disclosing information about agency function would of course not be harmful per se. Cf. Freedom of Information Act $\$ 552$ (b), 5 U.S.C. $\$ 552$ (b) (2000) (noting limited exceptions to public release of agency documents). However, an employee's release of distorted or incomplete information could show the agency in a bad light, making it more difficult to achieve its preferred policies.

243 See, e.g., Deborah Schoch \& Kenneth R. Weiss, Norton Admits 'Mistake;' Refuge: Interior Secretary Says She Mischaracterized Effects of Alaska Oil Drilling on Caribou Reproduction, L.A. Times, Oct. 20, 2001, at A18 ("Documents released by an environmental advocacy group that represents government employees show that a review of caribou impacts by the Fish and Wildlife Service-an agency Norton oversees-was substantially 
administration, EPA "holdovers" that disagreed with the White House's "Clear Skies" initiative to cut back air-quality enforcement actions against public utilities and replace it with an emissions trading system apparently disclosed internal agency documents to attempt to show that the initiative would not adequately protect air quality as well as arguably improper influence on administration policymaking by energy industry lobbyists. ${ }^{244}$ Such releases can inspire resourceconsuming congressional investigations or lower the agency's reputation or effectiveness.

A recent story suggests potential subversion by civil service employees of a political appointee's decision. The acting head of the Bureau of Indian Affairs, Michael Anderson, prepared a document recognizing the Duwamish tribe on the last day of the Clinton administration. He has alleged that the document was altered by being stamped "Draft," probably by civil servants in the Bureau of Indian Affairs, and that, contrary to his wishes, it was never sent for publication. 245

Another interpretation of some of these "subversive" events could be that civil servants were attempting to stop inappropriate agency actions, including last-minute policy burrowing. In any event, however, from the perspective of the President and her political appointees, civil service employees with different points of view impeded the implementation of policy decisions.

Active subversion may be deterred either by a sense of professionalism among agency employees or the threat of monitoring by su-

changed in Norton's letter to [Congress]."); Philip Shabecoff, Alaska Oilfield Report Cites Unexpected Harm to Wildlife, N.Y. Times, May 11, 1988, at A1 (discussing findings of unreleased preliminary report of Fish and Wildlife Service alleged to have been "deliberately suppressed" by the Interior Department).

244 While the sources cannot be conclusively determined simply from newspaper articles, EPA staff apparently released documents outside the agency in April 2001 and earlier, either directly to the media or to other organizations that then made them available to the media. See, e.g., Neela Banerjee, Files Detail Debate in E.P.A. on Clean Air; Environmentalists Discern a Challenge to Controls on Pollution, N.Y. Times, Mar. 21, 2002, at A32 (noting that EPA documents disclosed to Natural Resources Defense Council "show that some career officials ... . were concerned that changes that political appointees in the agency were considering would violate the Clean Air Act and loosen crucial standards on controlling pollution"); Katharine G. Seelye, White House Rejected a Stricter E.P.A. Alternative to the President's Clear Skies Plan, N.Y. Times, Apr. 28, 2002, at A26 (documenting EPA proposal's significant health and financial benefits, in contrast to allegedly less environmentally protective Bush White House proposal for which "[n]o comparable analysis exists").

245 See Paul Shukovsky, Charges Fly in Duwamish Case; Official Who Ruled for Tribal Recognition Says That His Document Was Altered, Seattle Post-Intelligencer, Jan. 11, 2002, 2002 WL 5926195 ("'I think this is a typical reaction by lower-level career staff doing what they can to stop a decision from going forward that they disagree with." (quoting Bob Anderson, Director of University of Washington's Native American Law Center)). 
pervisors. Agency employees that decide to stay on from one presidential administration very often are motivated by a sense of commitment to civil service, including a willingness to supply "responsiveness to the legitimate political leaders of the day."246 At a minimum, agency employees will be motivated to perform in order to retain the benefits of government employment. ${ }^{247}$ Moreover, if monitoring is close, it may be an effective deterrent, since true subversion probably would constitute sufficient cause to fire a civil servant. ${ }^{248}$

Despite these deterrents, an outgoing administration's hiring and promotion of employees with viewpoints different from those of the President-elect would seem to increase the risk of subversion and inefficiency beyond that generally presented by the career civil service. The new administration is likely to have to expend even more resources on monitoring these officials to reduce the risk of subversion $^{249}$ or may, if a trust relationship is not quickly established, "freeze out" employees especially hired or promoted by the previous administration. High-level career civil service holdovers suspected of being too loyal to an earlier administration's goals may become the equivalent of "Assistant Secretary for Nothing at All" 250 or a press secretary that is not permitted to take calls from the press. Additional monitoring and freezing out, of course, divert resources from other

246 Heclo, supra note 235 , at 20.

247 See, e.g., supra notes 224-25 and accompanying text (commenting on civil service "lifers"). As discussed above, this motivation seems more likely than the desire to distribute rents to private interest groups in order to maximize the civil servants' chances of lucrative private sector employment. To the extent the latter motive is operating, however, it might stimulate some active subversion. See also supra note 226 (discussing prospect that private employers will not wish to hire those who subvert employing organization).

2485 C.F.R. $\$ 752.301$ (2003) (permitting firing civil servants for cause); cf. Barnard v. Jackson County, Mo., 43 F.3d 1218, 1224-25 (8th Cir. 1995) ("[F]ew would dispute the President's authority to terminate a staff member who had a propensity to 'leak' sensitive information to the press before the President was informed of it.").

249 See, e.g., Stephen Barr, Agency Reorganizations, 'Burrowing In' Targeted, Wash. Post, Dec. 7, 1992, at A13 ("Worries by the winning team in previous presidential elections that the losers would dig into the government-and later throw sand into the new administration's machinery - are a staple of transitions."). The anonymous interviews conducted for this paper support this view; research condufted by Joel Aberbach and Bert Rockman also discusses efforts made to monitor the civil service in the Eisenhower and Nixon administrations. See Joel D. Aberbach \& Bert A. Rockman, Clashing Beliefs Within the Executive Branch: The Nixon Administration Bureaucracy, 70 Am. Pol. Sci. Rev. 456, 45657 (1976) (stating that Eisenhower administration "suspected the federal bureaucracy of disloyalty to its own policy preferences[,] . . . [and t]he Nixon administration also came to power suspicious of the existing bureaucracy").

250 See Barr, supra note 249; Merrill, supra note 238, at 85 . Despite the quote, typically an assistant secretary is a political appointee, rather than a career civil servant. 
agency work and limit the ability of career civil servants to contribute. ${ }^{251}$

\section{Salutary Effects of Burrowing}

Policy and personnel burrowing can impose potentially significant costs on a new President seeking to implement her own slate of policy preferences. Although those costs might support the claim that such burrowing undermines the electorate's choice and is therefore antidemocratic, a presidential election process may be far from a determinate communication of electoral views on issues agencies face. When this is the case, or when public opinion is not well formed or well informed, burrowing actions can have significant benefits. Even the most troublesome cases of personnel burrowing and some forms of policy burrowing can make positive contributions to the democratic responsiveness of agency decisionmaking. As this Section argues, policy entrenchment may generate a national dialogue on a particular policy issue and contribute valuable information to the public's understanding of an issue; personnel entrenchment can result in a more politically diverse internal agency dialogue on policy issues. Some forms of burrowing also can further the goal of agency accountability. Personnel burrowing may result in increased monitoring of agency activity, while policy entrenchment through rulemaking may amount to an agency constraining its own discretion in a binding way, reducing the potential for arbitrary agency conduct and increasing the extent to which the agency is governed by the rule of law.

\section{Contributions to the Legitimacy of Agency Decisionmaking}

Under a presidential control model, the voters' election of a President does not simply choose a leader, but also, critically, transmits electoral preferences on issues that administrative agencies may face. ${ }^{252}$ One could argue that the fact that a decisionmaker is popularly chosen is sufficient for a government to be legitimate and deemed democratically representative, whether or not particular gov-

251 Monitoring costs do seem to dwindle as the incoming political appointees learn to have confidence in the competence, professionalism, and loyalty of the civil servants from the previous administration. See, e.g., Paul C. Light, When Worlds Collide: The PoliticalCareer Nexus, in The In-and-Outers, Presidential Appointees and Transient Government in Washington 156, 158-59 (G. Calvin Mackenzie ed., 1987) (asserting that most political appointees conclude that careerists are competent and responsive, though realization may take some time). To the extent this confidence does not develop, the civil servant ultimately may leave the government, with or without encouragement.

252 See supra text accompanying notes 96-106. 
ernment decisions respond to popular preferences. ${ }^{253}$ However, the dominant view, and the one this Article adopts, sees the collection of and some responsiveness to public views as intrinsic to administrative legitimacy. ${ }^{254}$ Under this view, administrative accountability to an elected President can earn the agency some legitimacy not because the President has won the election, but because the national election suggests that the President's preferred policies (to which the agency is likely to respond) reflect electoral preferences as well. ${ }^{255}$

However, this may not always be the case. The presidential election may be far from a perfect electoral communication regarding many administrative policy questions. ${ }^{256}$ For a host of issues addressed by administrative agencies, the electorate at large simply may lack, ex ante, well-developed or even informed preferences, ${ }^{257}$ let alone consensus preferences on most significant issues. ${ }^{258}$ Take arsenic standards in water, for example, or the treatment of incomplete scientific data by food safety regulatory authorities. For these types of issues, it is very hard to conclude that voters have well-formed "prepolitical" viewpoints. ${ }^{259}$ A pollster trying to determine, at even a basic level, whether the general public favors stricter pollution control

253 See, e.g., Pitkin, supra note 72 , at 4 (discussing Hobbesian representation); id. at 170 , 186 (discussing Burkean representation: "insofar as solutions can be found, the way to find them is through rational consideration of the issues by wise men"); Calabresi, supra note 79 , at 53 ("[P]olitical accountability can readily be made into a justification for agency action which furthers what the commissioner . . . believes to be right, regardless of majoritarian desires ....").

254 See supra text accompanying notes 116-26 (remarking on Seidenfeld's view of President as supplying a check on agency deliberative efforts in view of electoral preferences); Mashaw, supra note 46, at 94-95 (characterizing President as conduit for electoral preferences); Stewart, supra note 75 , at 1670 (conceiving of administrative process as venue for representation of wide range of interests).

255 In addition, the President's desire for reelection will serve as an incentive to remain informed of and responsive to public preferences.

256 See, e.g., Calabresi, supra note 79, at 53 ("Political accountability leads almost inevitably to an overblown faith in one's capacity to know what the majority wants ....").

257 Cf. Spence \& Cross, supra note 72, at 106 ("Voters want government to do what they would have done if they had the time and resources to devote to the problem."). See generally Pitkin, supra note 72, at 219 ("Most people are apathetic about politics ...."); Levine \& Forrence, supra note 72 , at 185 ("It is expensive to educate the general public and to keep them informed."); Richard H. Pildes \& Cass R. Sunstein, Reinventing the Regulatory State, 62 U. Chi. L. Rev. 1, 99 (1995) ("People rarely have enough information to participate at all, or in a sufficiently informed way, in the processes of government.").

258 See Farina, supra note 96, at 995.

259 See, e.g., Wood \& Waterman, supra note 33, at 146 ("On the vast majority of issues dealt with by the bureaucracy, citizens have no specific demands or needs; they operate in a vague, impressionistic world ...."); Pildes \& Sunstein, supra note 257, at 75 (advocating more direct participatory mechanisms to equip groups of citizens to evaluate problems involving risk and to "express their judgments ... about risk[ ]" to help inform administrative judgments); Spence \& Cross, supra note 72, at 107-08 (assuming voters know they lack information necessary to make fully informed choices). 
regulation might have a difficult time. ${ }^{260}$ Cynthia Farina has argued that as a general matter, "we hold incompatible expectations and dissonant demands," making the job of a representative trying to represent the "will of the people" exceedingly difficult. ${ }^{261}$

Even if the voters have preferences, developed or inchoate, they may not have expressed them by electing one President or another. Under some circumstances-perhaps a highly visible policy debate during the presidential campaign coupled with landslide election results-the presidential election could be interpreted as an expression of the majority's preferences on a particular policy issue. Even though a newly elected President in these circumstances may act as though she has a "mandate" for a particular policy, for many policy issues, national elections for President are unlikely to carry any reliable message on voter preferences. ${ }^{262}$ This is so for several fairly obvious reasons.

First, as is clear to any casual observer of presidential campaigns and debates, a candidate may never be publicly confronted with a particular issue during a campaign. A candidate may not communicate her preferences clearly even when confronted or she may formulate her preferences only after the election. A voter thus may find it quite costly to determine the candidate's specific preferences. ${ }^{263}$

Second, even if a particular policy question has been raised and debated during a campaign, the structure of the presidential election may not allow voters to communicate their preferences effectively. Under our party system, voters rarely have more than two presidential

260 Half of Americans in one poll called environmental protection a "top priority," but two-thirds of those in another poll said they felt "good" about the quality of the air, water, and environment where they lived and worked. See Environment: Red Flags, at http:// www.publicagenda.org/issues/red_flags_detail.cfm?issue_type $=$ environment\&list $=1 \&$ area $=1$ (last visited Apr. 8, 2003) (comparing Princeton Survey Research/Pew poll with Louis Harris \& Associates poll).

261 Farina, supra note 96, at 1000; see also Bennett, supra note 199, at 864-65 (noting that vote does not reflect weight that voters place upon various interests). Perhaps needless to say, where the views of the general public are not fully formed, organized interest groups similarly will be unable to present an appropriate array of views within the administrative process.

262 See Heclo, supra note 235 , at 10-11 ("Whether the electoral margin is narrow or wide, there is no way to distinguish to what, among all the things that are said in an election campaign, the mandate applies."); cf. Seidenfeld, supra note 44, at 475 (discussing lack of mandate to Reagan to cut back environmental protections).

263 Pitkin argues in connection with congressional campaigns that after the transmission of information through local parties, the media, interest groups, and so forth, voters "may get simple positive or negative cues about [a candidate] ... which no longer have a recognizable issue content." Pitkin, supra note 72, at 223 (quoting Warren E. Miller \& Donald E. Stokes, Constituency Influence in Congress, 57 Am. Pol. Sci. Rev. 45, 55 (1963)); see also Seidenfeld, supra note 46 , at 19 (finding that "it is a great burden to educate a dispersed set of voters" on particular regulatory issues). 
candidates to choose from in the general election. As a consequence, voters generally are faced with a choice between individuals representing two discrete packages of policy preferences. A voter may support a candidate based on her policy preference on one key issue, despite the fact that on other issues the candidate's preferences do not resemble the voter's. Typically, voters in "large measures cast their ballots in accordance with their perceptions of a candidate's general ideology." 264 A voter's preference for a candidate may mean simply that the voter finds the candidate more or less "pro-big-government," for example, than the other candidate. This makes sense because voters must select a candidate without knowing what issues may arise in the future and must make a prediction about how the candidate will address different sorts of issues. The vote, however, does not distinguish among the reasons for support and consequently cannot-or should not-be read, as a referendum, to communicate preferences on any particular issue or even on a broader category of issues. ${ }^{265}$

Finally, even assuming that the public does possess well-formed preferences on a particular issue that was publicly raised during a presidential campaign, those views are likely to be heterogeneous. Unless she was elected by an overwhelming majority of the electorate-a rare occurrence given typically low voter-turnout rates - the President's preferences may not represent even the well-formed views held by a substantial portion of the nation. And popular landslides in a presidential election are rare: "Presidential politics can be conducted quite successfully with the support of considerably less than an electoral majority."266

a. Policy Burrowing as a Creator of Public Dialogue: The Roadless Areas Rule as a Case Study

Typical presidential election characteristics, including muddy policy messages and thin electing majorities, suggest that a new President can make only a tenuous claim to a complete democratic mandate. Moreover, even with a clear electoral message, a single-minded focus

264 Seidenfeld, supra note 48, at $1568-69$; see also Mashaw, supra note 46 , at 95 ("Citizens vote for a president based almost wholly on a perception of the difference that one or another candidate might make to general governmental policies."); Seidenfeld, supra note 44 , at 486 (stating that voters vote based on perception of candidates' general ideologies).

265 See Farina, supra note 96, at 998 (noting "bundling problem" in presidential voting); see also Bennett, supra note 199 , at 865 (noting that popular vote does not "disaggregate positions on the variety of issues that representatives will have to decide"). But cf. Seidenfeld, supra note 48, at 1553-54 (arguing that presidential appointments will guide agency policymaking effectively if particular issues were addressed in electoral process).

266 Farina, supra note 104, at 128. 
on the majority's preferences within the administrative state might subject it to criticism as overly responsive to a majoritarian faction. ${ }^{267}$

Late-term policy entrenchment by an outgoing administration potentially can counteract this problem. In particular, it can offset the prospect that agencies might consider only majority views among the electorate (or simply the President's views), raise public awareness regarding an issue that escaped attention during the presidential campaign, or create a sharpened public dialogue on a policy question. With respect to such a policy question, the dialogue may serve-sometimes more effectively than the presidential election-to communicate the public's policy preferences to the administrative agencies.

A recent Clinton administration rule declaring certain large roadless parcels of national forests off-limits to road-building-the socalled "roadless areas rule"-illustrates a late-term policy decision that generated a public dialogue. As discussed below, it also illustrates an agency's development of self-restraining, binding criteria. Thus, the case is worth developing in some detail.

Prior to the Clinton administration, the question of whether to build a road through a national forest was largely left to individual forest supervisors who work for the United States Forest Service, which in turn is located within the United States Department of Agriculture. In its major forest management statutes, Congress required the Forest Service to prepare a land management plan for each national forest, but imposed only general criteria for plan development. ${ }^{268}$ In addition, Congress provided very general principles to the Agriculture Department on how to manage the national forests. This guidance came in the form of long, inclusive statutory lists of appropriate forest uses or purposes. The Agriculture Department was to administer the national forests for "multiple use[s],"269 including "outdoor recreation, range, timber, watershed, and wildlife and fish purposes." 270 Elsewhere, Congress suggested generally that the Forest Service should "be a leader in assuring that the Nation maintains a natural resource conservation posture that will meet the requirements of our people in perpetuity."271

By not clearly prioritizing the various potential uses of forest lands, the statutory scheme leaves the Agriculture Secretary with con-

267 Cf. The Federalist No. 10 (James Madison) (arguing that government should guard against dangers of majority faction).

268 National Forest Management Act $\$ 6,16$ U.S.C. $\$ 1604$ (2000).

269 Multiple-Use Sustained-Yield Act of $1960 \$ 2$ 2, 16 U.S.C. $\$ 529$.

${ }^{270}$ Multiple-Use Sustained-Yield Act of $1960 \$ 1,16$ U.S.C. $\$ 528$; see also National Forest Management Act, 16 U.S.C. $\$ \$ 1600-1650$.

271 National Forest Management Act $\$ 2(6), 16$ U.S.C. $\$ 1600(6)$. 
siderable discretion to decide how national forests are to be managed as well as the authority to issue "such regulations as he determines necessary and desirable."272 That discretion extends to road-building: The Secretary generally is authorized to build roads and to grant easements for road rights of way in national forest lands ${ }^{273}$ consistent with the land management plans.274 Apart from consistency with land management plans, Congress furnished little else in the way of guiding principles for road-building decisions.

Within the Agriculture Department, regulations and internal directives generally delegate the responsibility to individual forest supervisors to plan access needs, select road locations, and negotiate all details of road construction and use agreements. 275 Individual forest supervisors often wish to respond to local desires for access in roadless areas, such as the desires of timber companies and farmers that wish to graze livestock on public lands. ${ }^{276}$ While some forest plans for roadless areas did pronounce that they were to remain roadless, many apparently contemplated the building of roads at some point.

In 1998, under the direction of the Forest Service Chief, Dr. Michael Dombeck, who was concerned about the ecological harm from poorly maintained roads, the Forest Service issued an Advance Notice of Proposed Rulemaking. The publication took note of "the costs associated with resource development, including road-build-

272 National Forest Management Act $\$ 15,16$ U.S.C. $\$ 1613$.

273 See An Act to Enable the Secretary of Agriculture to Construct and Maintain an Adequate System of Roads and Trails for the National Forests, and for Other Purposes $\$ 2$, 16 U.S.C. $\$ 533$ (easement grants); An Act to Enable the Secretary of Agriculture to Construct and Maintain an Adequate System of Roads and Trails for the National Forests, and for Other Purposes $\$ 4,16$ U.S.C. $\$ 535$ ("acquisition, construction, and maintenance of forest development roads").

274 National Forest Management Act $\$ 6(i), 16$ U.S.C. $\$ 1604$ (i) (requiring consistency with land management plans).

275 Agriculture Department regulations authorize the Chief of the Forest Service to undertake all road-building decisions, including issuing permits for others to construct a road across forest lands or constructing roads outright. E.g., 36 C.F.R. $\$ \$ 212.6,212.9(\mathrm{a}), 212.10$ (2002). Internal Forest Service Directives appear to delegate the authority still further, to the level of individual forest supervisors. See U.S. Dep't of Agric. Forest Serv., Forest Service Manual $\$ 5467.04 \mathrm{~d}$, http://www.fs.fed.us/im/directives/fsm/5400/5460.txt (last visited Apr. 8, 2003). As a general matter, the Forest Service Directive system "consists of the Forest Service Manual and Handbooks, which codify the agency's policy, practice, and procedure. The system serves as the primary basis for the internal management and control of all programs ...." See U.S. Dep't of Agric. Forest Serv., Overview of the Forest Service Directive System, at http://www.fs.fed.us/im/directives/dughtml/overview.html (last modified Nov. 3, 1997).

276 See, e.g., Herbert Kaufman, The Forest Ranger: A Study in Administrative Behavior 75-80 (Johns Hopkins Paperbacks ed. 1967) (explaining local pressures on individual forest rangers). 
ing," 277 and declared its intention to consider whether forest road system management should be adjusted in view of "changes in public opinion, public demand, and public use of national forest resources," as well as greater information about the "benefits and environmental impacts of roads." 278

Simultaneously, the Forest Service issued a road-building "timeout"- a temporary suspension of road construction and reconstruction in most unroaded areas-in order to permit consideration of its road system policies. ${ }^{279}$ The Forest Service received approximately 80,000 comments in response to the Advance Notice. A year later, in February 1999, the Forest Service issued a Final Interim Rule, again temporarily suspending permanent and temporary road construction and reconstruction in most unroaded areas pending development of a revised transportation system policy, or eighteen months, whichever would come sooner. ${ }^{280}$ A few months later, with President Clinton now a year from the end of his term, the White House became more directly involved.

In October 1999, President Clinton issued a "Memorandum for the Secretary of Agriculture." He noted that the existence within the National Forest System of over forty million acres of "roadless" areas-"some of the last, best unprotected wildlands in America ... a treasured inheritance-presented a "unique historic opportunity." 281 He instructed the Secretary of Agriculture to "develop, and propose for public comment, regulations to provide appropriate long-term protection" for roadless areas. 282

The memorandum and the Forest Service notices provoked opposition. The rule's result obviously would make millions of acres of timber more difficult to harvest, and the timber industry unsurprisingly opposed the rule. ${ }^{283}$ The House and Senate both had oversight

277 Administration of the Forest Development Transportation System, 63 Fed. Reg. 4350 (proposed Jan. 28, 1998) (to be codified at 36 C.F.R. pt. 212).

278 Id.

279 Id. at 4354.

280 See Adoption of Interim Rule, Administration of the Forest Development Transportation System: Temporary Suspension of Road Construction and Reconstruction in Unroaded Areas, 64 Fed. Reg. 7290 (Feb. 12, 1999) (to be codified at 36 C.F.R. pt. 212).

281 Memorandum from William J. Clinton, President, to the Secretary of Agriculture (Oct. 13, 1999), 1999 WL 820246 (regarding "Protection of Forest Roadless Areas").

282 Id.

283 As an administrative measure to restrict road access to these areas, the rule also was viewed by some as an end run around congressional authority. The Wilderness Act requires the Forest Service to inventory roadless areas of 5000 acres or more to determine whether a wilderness designation is appropriate and provides significant protections for land designated as wilderness. However, wilderness designations can only be made by statute. See Wilderness Act \&3(c), 16 U.S.C. \$ 1132(c) (2000). The Forest Service had used the Wilderness Act inventories to develop the roadless areas initiative. 
hearings to discuss the rule, and Congress did, at one point, enact a rider to appropriations legislation requiring the Forest Service to report to Congress on the initiative and to pay compensation to states for timber sales lost as a result of the moratorium. ${ }^{284}$

Nonetheless, the Forest Service proceeded to try to complete the rulemaking process as quickly as possible. In October 1999, Forest Service Chief Dombeck sent a letter to Forest Service employees suggesting that prompt completion of the required environmental analysis that would accompany a roadless areas rule was an "urgent need" and that the Forest Service "[could] not afford to waste a single day."285 On May 10, 2000, the Forest Service published a proposed rule that would bar building and reconstruction of roads in the inventoried roadless areas-approximately 54.3 million acres of Forest Service lands. ${ }^{286}$ The Forest Service provided several weeks to receive written comment on the proposed rule and scheduled a large number of public meetings across the country to publicize the proposed rule and to take comments. ${ }^{287}$ At the close of the comment period, it was estimated that the Forest Service had received over one million comments since 1998, most reportedly positive about the proposal. ${ }^{288}$

On January 12, 2001, eight days before President Clinton left office, the Forest Service issued a final rule to "protect and conserve inventoried roadless areas on National Forest System lands."289 The rule barred not only road-building but also timber harvesting in the roadless areas. It further limited the previous discretion of the forest supervisors to make road-building decisions that might vary depending on either the particular configuration of groups interested in a particular forest (timber companies, hikers and tourists, wildlife

284 Because the appropriations legislation also contained money for the troops in Bosnia and for victims of natural disasters, it was, as a practical matter, veto-proof. Although President Clinton termed the rider "objectionable," he signed the legislation. Statement on Signing the 1998 Supplemental Appropriations and Rescissions Act, 1998 Pub. Papers 662,662 (May 1, 1998).

285 The State of Idaho presented this memorandum to the district court in its later-filed litigation challenging the roadless areas rule. See Complaint of State of Idaho at para. 14, Idaho ex rel. Kempthorne v. U.S. Forest Serv., 142 F. Supp. 2d 1248 (D. Idaho 2001) (No. CIV01-011-N-EJL).

286 See Special Areas; Roadless Area Conservation, 65 Fed. Reg. 30,276 (proposed May 10, 2000) (to be codified at 36 C.F.R. pt. 294). On about 24 million acres covered by the rule, existing forest management plans already prohibited road-building. Id.

287 See Special Areas; Roadless Area Conservation, 66 Fed. Reg. 3244, 3248 (Jan. 12, 2001) (to be codified at 36 C.F.R. pt. 294). The Forest Service also had solicited additional public comment on its preparation of a draft environmental impact statement accompanying the rule. Id.

288 See Eric Pianin, Ban on Road Building in Forests Is Blocked, Wash. Post, May 11, 2001 , at A3.

289 Special Areas; Roadless Area Conservation, 66 Fed. Reg. at 3244. 
preservation groups) or the values selected by political appointees in the agency. ${ }^{290}$ Instead, it created a new presumption that roadless areas would remain roadless, except in a narrowly limited set of circumstances.

The Forest Service issued the rule despite knowing at the time that President-elect Bush was not supportive of the proposal.291 Moreover, as before, the timber and energy industries complained that it would deny them access to timber and natural gas resources. Western states and Republican lawmakers called the plan "hasty and irresponsible." 292 The new chairman of the House of Representatives Resource Committee, Representative Jim Hansen of Utah, said, "I will make it a priority to undo this kind of reckless, last-minute maneuvering."293

The Bush administration did its best to reverse course. On January 21, 2001, Chief of Staff Andrew Card issued a memorandum delaying the effective dates of all final regulations that had not yet taken effect, ${ }^{294}$ including the roadless areas rule. ${ }^{295}$ After the State of Idaho had filed litigation challenging the rule as having been adopted without full compliance with the environmental analysis requirements of the National Environmental Policy Act (NEPA), ${ }^{296}$ the Bush administration indicated that it would not be defending the rule on the merits. ${ }^{297}$ Idaho then moved for a preliminary injunction against implementation of the rule. The United States Forest Service did not challenge Idaho's NEPA arguments, but instead responded that the court "could fashion an appropriate remedy-including a one to two

290 The United States Forest Service was quite explicit that it wished to restrict just this type of discretionary decisionmaking. See, e.g., id. at 3246 ("Local land management planning efforts may not always recognize the national significance of inventoried roadless areas and the values they represent in an increasingly developed landscape.").

291 See Douglas Jehl, Road Ban Set for One-Third of U.S. Forests, N.Y. Times, Jan. 5, 2001 , at A1.

292 Id.

293 Patty Reinert, Executive Orders to Face Scrutiny; Bush, Lawmakers Vow Close Look at Clinton's Last-Minute Moves, Houston Chron., Jan. 6, 2001, at 6A (quoting Hansen and noting also that Republican senator and chair of Senate Energy Committee Frank Murkowski called Clinton's plan "fatally flawed").

294 See supra note 163.

295 See Special Areas; Roadless Areas Conservation: Delay of Effective Date, 66 Fed. Reg. 8899 (Feb. 5, 2001) (to be codified at 36 C.F.R. pt. 294).

296 Idaho ex rel. Kempthorne v. U.S. Forest Service, 142 F. Supp. 2d 1248 (D. Idaho 2001).

297 E.g., Federal Defendants' Opposition to Plaintiff's Motion for Preliminary Injunction at 4-5, ldaho ex rel. Kempthorne (No. CIV 01-011-N-EJL) (making no argument regarding likelihood of success on merits in opposing preliminary injunction); see Douglas Jehl, Bush Will Modify Ban on New Roads for U.S. Forests, N.Y. Times, May 4, 2001, at A1 (reporting that Bush administration had not yet informed judge of its position on rule). 
month stay of the effective date of the regulation."298 On May 10, 2001 , the district court enjoined implementation of the rule. ${ }^{299}$ In mid-December 2002, a panel of the Ninth Circuit Court of Appeals wrote an opinion reversing the district court; the court is now considering a petition for en banc review. ${ }^{300}$

Although the government did not appear before the Ninth Circuit and was less than enthusiastic in defending the rule before the district court, ${ }^{301}$ senators hearing the subsequent confirmation of the relevant Justice Department official, Thomas Sansonetti, the Assistant Attorney General for Environment and Natural Resources, extracted commitments from him to defend the roadless areas rule. ${ }^{302}$

Press coverage was extensive. Newspapers with national circulation, such the New York Times, the Wall Street Journal, the Los Angeles Times, and the Washington Post reported on the details of the roadless areas rule and the Bush administration's response to it, the progress of lawsuits against the rule, and public reaction. ${ }^{303}$ In addition to environmental groups and over one hundred congressional Democrats, a number of congressional Republicans also urged Bush to support the rule. ${ }^{304}$ Public opinion polls were conducted suggesting that "voters believe[d] the Republicans [were] placing business inter-

298 Federal Defendants' Opposition to Plaintiff's Motion for Preliminary Injunction at 4, Idaho ex rel. Kempthorne (No. CIV 01-011-N-EJL).

299 Order at 3, Idaho ex rel. Kempthorne (No. CV-11-N-EJL).

300 See Kootenai Tribe v. Veneman, 313 F.3d 1094 (9th Cir. 2002). At the time this Article went to print, due to the petition's filing, the court had not yet issued the mandate implementing the panel opinion and vacating the preliminary injunction. See Fed. R. App. P. 41(d)(1) (providing that timely filing of petition stays mandate). The Ninth Circuit also had not yet ruled on the petition. See Kootenai Tribe v. Idaho Conservation, No. 01-35472 (9th Cir. petition for rehearing en banc filed Dec. 24, 2002). The roadless areas rule faces further challenge in pending litigation in the District of Wyoming, Wyoming v. U.S. Dep't of Agric., No. 01-CV-0086 (D. Wyo. filed May 18, 2001), and the District of North Dakota, Billings County, N.D. v. U.S. Dep't of Agric., No. 01-CV-0045 (D.N.D. filed May 8, 2001).

301 See, e.g., Testimony of McGarity, supra note 17, at 1-2 (mentioning failure of government to challenge preliminary injunction before Ninth Circuit).

302 See, e.g., Confirmation Hearing on the Nomination of Thomas L. Sansonetti to Be Assistant Attorney General: Hearing Before the Senate Comm. on Judiciary, 107th Cong. 74-75 (2001) (reporting colloquy between Senator Maria Cantwell and Assistant Attorney General for Environment and Natural Resources Thomas Sansonetti in which Sansonetti offered verbal commitment to defend roadless rule against legal challenge).

303 For a few of the numerous articles in these three newspapers discussing the roadless areas rule in 2001, see, e.g., Environmentalists Fear Sign That Bush Might Reverse New Rules on Forests, L.A. Times, Mar. 17, 2001, at A18; Douglas Jehl, U.S. Offers Further Delay to Forest Rules; Clinton Policy Is Said to Need More Study, N.Y. Times, Mar. 17, 2001, at A7; Eric Pianin, White House Seeks to Scuttle Clinton Ban on Logging, Roads; Bush Asks Justice Dept. Lawyers to Reopen National Forests, Wash. Post, Apr. 26, 2001, at A13.

304 Eric Pianin, 20 in GOP Urge Bush to Back Clinton Logging Rules, Wash. Post, May 2, 2001, at A4. 
ests ahead of the environment;" and some members of Congress perceived that "there's a constituency out there for the environment, and they're engaged." "305 Most recently, over 175 members of the House of Representatives cosponsored legislation in 2002 that would have enacted the roadless rule as a statute. ${ }^{306}$

Ultimately, despite the issuance of the preliminary injunction, the Bush administration elected not to reverse course immediately on the roadless areas rule. In early May 2001, the Washington Post reported that the Bush administration would let the roadless areas regulation stand, thereby "avoid[ing] another confrontation with environmental groups and congressional Democrats over a major environmental issue." 307 The administration left an opening for change, however, by suggesting it would "allow the U.S. Forest Service to reconsider on a park-by-park basis what rules are best for protecting roadless areas in a way that would give more weight to the concerns of local businesses, residents, and government officials." 308

As a general matter, the Bush administration took administrative action to adapt Forest Service policy in the direction of the rule's policy choices. In interim directives issued in the latter half of 2001, the Forest Service withdrew authority from local forest managers and provided that for road-building proposals which the roadless rule would have prohibited, the Forest Service Chief generally would make all such decisions. ${ }^{309}$ As of this writing, the Forest Service Chief appar-

305 See Juliet Eilperin, GOP Won't Try to Halt Last Rules by Clinton; Hill Power Shift Forces Retreat on Spring Plans, Wash. Post, July 30, 2001, at A1 (quoting Democratic Representative George Miller).

306 See H.R. 4865, 107th Cong. (2002) (articulating purpose "[t]o protect inventoried roadless areas in the National Forest System, and for other purposes"); see also Bill Summary \& Status for the 107th Congress: H.R. 4865, at http://thomas.loc.gov/cgi-bin/bdquery/ z?d107:HR04865:@@@P (last visited Apr. 8, 2003) (listing cosponsors).

307 See Eric Pianin \& Mike Allen, Clinton Forest Rules to Stand; Bush Leaves Opening for Logging, Mining, Drilling, Wash. Post, May 4, 2001, at A1.

308 Id.; see also Kootenai Tribe v. Veneman, 313 F.3d 1094, 1106 (9th Cir. 2002) (noting that in 2001, Forest Service reported to federal district judge that it planned to amend rule to permit limited additional activity in roadless areas).

309 See generally Notice of Interim Administrative Directives, Forest Transportation System Analysis; Roadless Area Protection, 66 Fed. Reg. 65,796, 65,798 (Dec. 20, 2001) (to be codified at 36 C.F.R. pt. 212) (summarizing new interim directives). As of December, 2001, however, the directive does not apply after a forest's land management plan has been amended or revised. See id. at 65,801 ; see also, e.g., Brian Stempeck, No New Wilderness for Tongass, Says Forest Service, Greenwire, Mar. 3, 2003, http://www.eenews.net/Green wire/searcharchive/test_search-display.cgi? $q=$ TONGASS\&file $=\% 2 F G$ reenwire $\% 2$ Fsearch archive \%2FNewsline \%2F 2003\%2FMar3\%2F03030301.htm (noting that while "Forest Service Chief ... must personally approve timber sales in roadless areas ... [, ] national forests with up-to-date management plans in place," including Alaska's Tongass National Forest, "can proceed with logging contracts"). 
ently has yet to authorize any such roads. ${ }^{310}$ Further, the Department of Agriculture, within which the Forest Service is located, has stated that it is "committed to protecting and managing roadless values." 311

In its essential characteristics, the roadless areas rule is a fairly typical example of the most problematic form of "policy burrowing." The United States Forest Service promulgated the final roadless areas rule one week before President Clinton left office-well after the Clinton administration knew that the rule was controversial and notwithstanding the opposition of President-elect George Bush. Moreover, the Forest Service exercised its discretion to issue its policy in a relatively durable form. Rather than placing its policy in the Forest Service's system of informal directives to employees-a Forest Service Handbook or the Forest Service Manual-the Forest Service embodied its policy in a binding legislative rule, which could be changed only through another process of notice-and-comment rulemaking. ${ }^{312}$

The outgoing administration undoubtedly recognized that any effort to change this policy would be administratively costly and perhaps politically costly as well. Clinton Chief of Staff John Podesta publicly commented with respect to the roadless areas rule that "[r]eversing this kind of stuff ... is politically difficult, and a bureaucratic nightmare." 313 Perhaps the hope was that environmentalists would communicate their support for the particular policy to the Presidentelect and dissuade any later efforts to change the rule.

Further, the issuance of the roadless areas rule clearly imposed costs on the Bush administration's ability to develop its own policy agenda. Both the rule itself and the Bush administration's development of a policy response to it occupied considerable media attention and required considerable agency effort. Conceivably, had the Clinton administration taken no such action, the question of roads in national forests might never have reached the Bush administration's policy agenda at all.

310 See Douglas Jehl, Court Reinstates Ban on Building Forest Roads, N.Y. Times, Dec. 13,2002 , at A32 ("Even during the 19 months that the rules were blocked [by the preliminary injunction], the administration stopped short of approving projects that would have violated the Clinton protections.").

311 Elizabeth Shogren \& Bettina Boxall, Ban on Roads in Pristine National Forests Reinstated, L.A. Times, Dec. 13, 2002, at A34 (quoting Agriculture Undersecretary Mark Rey).

312 For more discussion of the Forest Service's decision to use a self-restraining mechanism to communicate its policy, see infra text accompanying notes 432-33.

313 See David E. Sanger, Bush Waits, Politely, to Undo What Clinton Has Done, N.Y. Times, Dec. 24, 2000, at A16 (quoting John D. Podesta). Podesta's "bureaucratic nightmare" probably refers to the time and resources required to develop a record that will justify a change of agency policy both to the public and in the event of judicial review. See supra text accompanying notes 151-61. 
It could be argued that the roadless areas rule does not represent inappropriate entrenchment, but simply an agency finishing something that had been "in the pipeline" for years. The project undoubtedly had a long lead time; the Advance Notice of Proposed Rulemaking was published in 1998. Moreover, difficult policy issues often may take considerably longer to resolve. ${ }^{314}$ Consequently, it could be argued that the timing of the rule's issuance - the same month that President Bush took office-was purely coincidental. Certainly both career civil servants and political appointees are highly motivated to finish projects before a change in administration-to obtain the sense of achievement and gratification that comes with a completed project, and to avoid the wasted effort and delay that might accompany having to bring new leadership up to speed on an ongoing project.

However, the issuance of this rule in final form was not in any sense ministerial. ${ }^{315}$ For example, the roadless rule was modified from its proposed form after the public comment period to make it even more proscriptive of actions in roadless areas. ${ }^{316}$ Moreover, given knowledge of the President-elect's opposition and repeated congressional inquiries and expressions of congressional disapproval, ${ }^{317}$ the Forest Service could have refrained from publishing the rule. It did not do so.

\section{b. Creation of a Public Policy Dialogue and Information "Benchmarks"}

Certainly, the roadless rule's costs for President George W. Bush include those described earlier. To the extent his administration opposed the roadless rule, administrative costs would be certain, and-if the outgoing administration had guessed correctly regarding public preferences-political costs also could accompany policy change. ${ }^{318}$ Without the roadless areas rule, the new administration could much more easily, if it wished, institute a preference for road-building, sim-

314 See A Rush to Regulate, supra note 36, at 117 (testimony of Thomas O. McGarity) ("It is in the nature of a deliberative law-making body to deliberate longer and harder over difficult decisions and, consequently, to leave them to the end of the deliberations.").

315 See generally supra text accompanying notes $285-93$.

316 For example, the final roadless areas rule included a restriction on timbering not explicit in the proposed rule. See Special Areas; Roadless Area Conservation, 66 Fed. Reg. 3244, 3257 (Jan. 12, 2001) (observing that final rule includes prohibition on timbering "not in the proposed rule").

317 See, e.g., H.R. Conf. Rep. No. 106-914, at 195 (2000) (discussing legislative restriction on spending on roadless areas and national monuments).

318 See, e.g., Katharine Q. Seelye, Imagine: Stealth Anti-Environmentalism, N.Y. Times, Dec. 23, 2001, $\$ 4$ (Week in Review), at 4 (describing Bush attempts to reverse Clinton-era regulations). Of course, if the Clinton administration incorrectly assessed likely public preferences on national forest use, political costs would be minimal. 
ply by informally instructing forest supervisors to grant road-building requests. Reversal of the rule would be much more visible and difficult.

However, the reason to consider the roadless areas rule is that it also illustrates some benefits of policy burrowing. First, burrowing may generate a broader policy dialogue between the public and the bureaucracy by, for example, engaging segments of the public not already mobilized by interest groups. That dialogue can in turn increase the democratic and participatory quality of agency decisionmaking. ${ }^{319}$

As discussed above, people's preferences on policy issues may not be fully formed at the time of an election. ${ }^{320}$ Further, an issue may not be debated during a presidential campaign or, even if it is, a presidential election simply may not communicate the preferences of the electorate on a particular policy issue. ${ }^{321}$ Especially if public views are not fully formed on a specific policy issue and the President would prefer not to focus on that issue, the President may have little incentive to further engage public views.

By comparison, the opportunity to entrench policy gives the outgoing administration the chance to elevate an issue on the public agenda and to sharpen public dialogue. ${ }^{322}$ Consider the policy entrenchment action that appears least savory, in which, as with the roadless rule, the departing administration codifies through a binding rule a policy position that is publicly opposed by the President-elect. Both the issuance of the rule and the new administration's action to reverse it make news. The press, which can serve as a "powerful" institution in reducing the unbridled discretion of administrative agencies, ${ }^{323}$ is more likely to cover the issue in detail. The departing administration's injection of political conflict on a particular issue raises its visibility with individual voters and with organized groups. ${ }^{324}$ This

319 See, e.g., Robert C. Post, Constitutional Domains: Democracy, Community, Management 186 (1995) ("[T]he notion that democratic self-determination turns on the maintenance of a structure of communication open to all commands an extraordinarily wide consensus.").

320 See supra text accompanying notes 256-61.

321 Id. As Ayres and Braithwaite also argue, even if citizen views were well-formed, the "power of all citizens to vote for those who make their laws" is "systematically undermined by unequal power relationships at the implementation stage." Ayres \& Braithwaite, supra note 127 , at 82 .

322 Cf. Bennett, supra note 199, at 872 (noting that "politician's primary incentive" may be to generate conversation that "will garner more votes at the next election than it will repel. This can easily lead to the simplistic and the petty").

323 Id. at 188.

324 As one interviewee put it, a significant change by a later administration from an outgoing administration's policy could "send a red flag up" to interest groups and "give them ammunition" as they try to influence agency agendas under a new administration. In the case of most such actions, the focal point for public dialogue is likely to be provided not 
is particularly so where the Presidents are involved, as with the roadless areas rule. The presence of the debate likely will give organized interest groups something around which to rally and will spur a broader array of voters to gain knowledge on an issue and consequently to develop an informed policy preference. ${ }^{325}$

In the context of the roadless areas debate, for example, despite the many comments received by the agency during the development of the rule, the vast majority of American voters probably were unaware of it before the final rule was issued. Moreover, since the issue was not a focal point of the presidential campaigns, it is hard to say that the electorate could have communicated a view on forest management policy. However, once the "last-minute rule" was issued and the new administration began taking steps to reverse it, a much more visible public dialogue began on the desirability of the roadless areas rule. ${ }^{326}$ Ultimately, the presence of the Clinton administration policy choice and the public response to the Bush administration proposed abandonment resulted in the Bush administration shifting its position to more closely resemble the choice of the outgoing Clinton administration.

Besides drawing public attention to a controversy, an outgoing administration's policy entrenchment efforts also can enrich an ongoing public policy dialogue by providing the public with an informational "benchmark" against which other alternatives can be measured. ${ }^{327}$ Especially if its policy position is embodied in a

simply by a sense that the actions of the outgoing administration are somehow inappropriate or unsavory, but instead by the fact that a clearly identifiable policy is being changed.

325 Levine and Forrence make a related point in arguing that "to the degree that one or another slack-reducing process puts an issue on the public agenda, slack diminishes drastically, and both capture and Burkean behavior become extremely difficult." Levine \& Forrence, supra note 72, at 192.

326 For example, press coverage mentioning the roadless areas issue over the twelvemonth period between May 2000 (when the proposed rule was issued) and May 2001 (when the Bush administration stated it would accept a modified version of the roadless areas rule that left it open to change on a forest-by-forest basis) was dramatically greater than the coverage of the issue during the 12 months of 1998, when Forest Service Chief Dombeck proposed a temporary moratorium on road building in roadless areas of national forests. A LEXIS/NEXIS search of its entire newspaper database for the words "roadless" and "national forest" found 588 articles written during 1998. From articles published between May 8, 2000, the week the proposed roadless areas rule was issued, and May 8, 2001, the week the Bush administration announced it would retain a modified version of the rule, LEXIS/NEXIS found 2069 newspaper articles mentioning these terms.

327 Richard H. Pildes \& Elizabeth S. Anderson, Slinging Arrows at Democracy: Social Choice Theory, Value Pluralism, and Democratic Politics, 90 Colum. L. Rev. 2121, 2142 (1990) ("Rationality must be understood to be a matter of interpretation and evaluation, not merely of aggregation and calculation."); Pildes \& Sunstein, supra note 257, at 105 (arguing that "good initial step" to increase democratic character of contemporary government would be "for government to provide enough information so that people could make 
rulemaking, the outgoing administration is likely to have investigated the feasibility of the policy, articulated the basis for choosing it, and developed a record supporting it. Consequently, the general public may receive a more thoroughly developed policy alternative, together with a supporting record, against which voters can compare other proposals, including those of the new President, Congress, and outside institutions.

Voters might evaluate the various policy options, including the outgoing President's actions, in view of information they already have about whether their policy preferences have tended to coincide-or have failed to coincide-with the preferences of the outgoing administration. In addition, because of the contrast between the outgoing administration's views and those of the incoming administration, voters are likely to better understand the continuum of possible policy options.

For a very simple example, consider the Clinton administration action setting arsenic standards for drinking water at ten parts per billion. The earlier standard had been fifty parts per billion. Without a Clinton administration action, voters might have been aware that some organizations were calling for a more stringent standard, ${ }^{328}$ but might not have had a sense of how stringent a feasible standard might be or whether the standard was warranted in light of its costs. Voters could infer that the agency's selection of the standard suggested at least some consideration of costs, benefits, and feasibility. ${ }^{329}$ Further, voters could benefit from a clarified debate on the health and cost consequences of that standard relative to the older standard. ${ }^{330}$ Moreover, the controversy over the rule prompted the development of

knowledgeable judgments"). Of course, such an advantage might be limited to the extent the general public is already fully informed and can effectively assess the implications of a particular policy proposal.

Setting a policy benchmark against which to measure the next administration's policies is sometimes a subjective purpose of an exiting administration's rulemaking decisions. This can be seen best in the context of last-minute rules that are issued in proposed, rather than final, form. These can be abandoned by the next administration with little or no administrative cost, but they can serve as a reference point in ongoing public debate.

328 See, e.g., Jehl, supra note 195 ("[I]n a 1999 review, the National Academy of Sciences recommended that the 50 parts-per-billion standard, set in 1942, be revised downward 'as quickly as possible."').

329 See, e.g., Anita Huslin, Debate Swells over Arsenic in Water Supply; Administrations Differ, Residents Worry About Levels, Wash. Post, July 5, 2001, at B1 ("[T]he new limit of 10 that the EPA chose was a compromise, after cost-benefit analyses showed that a limit of 5 micrograms of arsenic could mean millions of dollars more in costs, without any certainty that it would produce a markedly lower cancer risk.").

330 See, e.g., Jehl, supra note 195 ("[S]ome of the communities most affected . . . have been the loudest critics of the Clinton rules[, arguing] that those rules would impose many millions of dollars in costs on impoverished local water authorities."). 
more scientific research on the negative health effects of arsenic, which in turn sharpened the public debate and resulted in the Bush administration's retention of the rule. ${ }^{331}$

The late-term Clinton administration roadless areas rule created a similar sort of benchmark to inform public policy debate. In later public lands debates, the roadless areas rule has remained a reference point. For example, consider media coverage of a recent Forest Service recommendation under the administration of President George W. Bush to open nine million acres of the Tongass National Forest in Alaska to logging, mining, and road-building, while simultaneously recommending wilderness protection for 1.4 million acres of the state's Chugach National Forest. While "[Bush] [a]dministration officials said they were doing better than the Clinton administration [roadless rule]" by recommending a wilderness designation for national forest land, an environmental group commented, "Clinton said, You can't log or road in these areas, and now the Bush administration is saying, Have at it. They're pushing more than 30 timber sales in these areas." 332

Although the information from this more participatory, more focused debate may not be precisely or neatly communicated, it may reach the agency through a variety of means. Interest groups may convey these crystallized views and may try to organize new or more focused efforts around (or against) the outgoing administration's preferred policy. ${ }^{333}$ Members of the public also may comment directly upon the proposals, contact Congress, or communicate their views less directly through reporting and polling. ${ }^{334}$

331 See Beermann, supra note 4 , at 56 ("[A] scientific report requested by EPA concluded that even the Clinton administration had underestimated the negative health effect of arsenic.... [O]n October 31, 2001, the [Bush EPA] announced that the Clinton standard would go into effect as planned ....").

332 Katharine Q. Seelye, Forest Service to Recommend Opening Alaska Forest Area; Other Forest Is to Get Wilderness Protection, N.Y. Times, May 17, 2002, at A12.

333 See supra text accompanying notes $127-30$ (regarding interest groups and public choice theory).

334 See Wood \& Waterman, supra note 33, at 146 (maintaining that "continuing contacts with constituents, public opinion polls, the media, and other politicians" can assist bureaucracy in accurately translating public preferences); Stewart, supra note 75, at 1793 (noting that elections might stimulate public debate, which in turn might engender "more informed public scrutiny and control over agency policies").

These means of communicating public views are relatively indirect and may require interpretation, relative to the situation where the public indicates its preferences through, say, a one-issue referendum or through commenting on a rulemaking. Cf. Calabresi, supra note 79, at 110-11 (arguing that administrative agencies may be "reasonably adept at sensing current popular will" due to presence of staff and budgetary dependence on elected officials, though they may not be well suited to "task of discerning principles"). 
Of course, interest groups already may have been involved in the agency's development of policy, as was the case with the roadless areas rule. To the extent a broad segment of the general public lacks coherent or informed preferences on a particular issue prior to a broader public debate, however, neither the substantive content nor the intensity of public views is likely to have been communicated adequately by interest groups.

Besides participating more actively in debate on a specific issue, an informed electorate and informed interest groups generally will be better able to monitor and participate in agency processes. They might act directly in agency proceedings, invite the attention of other institutions, such as Congress, or (in the case of voters) register their concerns through the next election. ${ }^{335}$

Of course, the Clinton roadless rule is not the only example of a "burrowed rule" that can evoke greater public debate and provide the public with an informational benchmark on policy issues. For example, on its last day, the outgoing administration of George H.W. Bush sent to the Office of the Federal Register a proposed rule that would permit greater use of ethanol in reformulated gasoline, which is used to help particular regions meet clean air standards. ${ }^{336}$ The Bush administration's EPA signed the proposed ethanol rule and sent it to the Office of the Federal Register for publication notwithstanding earlier public expressions of opposition by Carol Browner, President Clinton's nominee for Environmental Protection Agency Administrator. ${ }^{337}$ The Clinton administration originally indicated that it would

Just as with other policy matters, an agency is likely to respond to public preferences in a "burrowing" controversy because of the discipline imposed by the presidential election and the elections of the members of Congress who oversee the agency and control its budget.

335 See McGarity, supra note 47, at 1450 ("Focused congressional inquiry and attention can enhance the agency's accountability to all of the citizenry and can be especially effective in stimulating the process ...."). As a corollary benefit, this type of dialogue also may generate feelings of personal meaning for participants. See, e.g., Robert W. Bennett, Democracy as Meaningful Conversation, 14 Const. Comment. 481, 504 (1997) (contending that public dialogue may create personal meaning for individual participant as it stimulates "sense ... of respectful engagement in the decision making process ... because that member's opinions . . . mattered"); see also Thomas Christiano, Deliberative Equality and Democratic Order, in Political Order 251, 251 (Ian Shapiro \& Russell Hardin eds., 1996) ("Some ... have argued that the process of social discussion among equals is itself intrinsically valuable....").

336 Bush Order May Benefit Big Illinois Contributor, St. Louis Post-Dispatch, Jan. 24, 1993, at 3A ("William K. Reilly, the [EPA] administrator, signed the pro-ethanol proposal Wednesday only two hours before Clinton was sworn in.").

337 See, e.g., EPA Nominee Won't Sign Bush's Ethanol Waiver If It Violates Law, Bloomberg News, Jan. 11, 1993, LEXIS, News Library (noting that Browner testified during confirmation hearings that she would not support rule permitting greater ethanol use if it was accompanied by increase in nitrogen oxides emissions). 
"scuttle" the George H.W. Bush administration proposal, but then permitted the proposed rule to be published for public comment. ${ }^{338}$ After public coverage of the issue, extensive comments during rulemaking, and public statements by the rule's "winners" and "losers" (oil and environmental groups on the side of less ethanol and corn growers on the side of the earlier Bush administration propo$\mathrm{sal}^{339}$ ), the Clinton administration eventually agreed to permit greater use of a refined form of ethanol. ${ }^{340}$ The earlier Bush administration proposal served as a reference point in public debate regarding the policy on ethanol use, and that debate spurred the Clinton administration to modify its position. ${ }^{341}$

For another example, a Carter administration proposed rule that sought to regulate nursing homes became a "benchmark" in the discussion of a range of later proposed Reagan administration reforms to nursing home regulation. During the last months of the Carter administration, the Department of Health and Human Services proposed new conditions for nursing homes that wished to participate in Medicare and Medicaid. ${ }^{342}$ These included both a patient "bill of rights," to help ensure the protection of patient privacy and property rights, and the creation of the so-called Patient Assessment and Care Evaluation System. ${ }^{343}$ Although the Carter rule did not become final, the Carter proposal did serve as a reference point for debate. After the

338 See Anne Hazard, EPA Lifts Ethanol Ban, States News Service, Jan. 29, 1993, LEXIS, News Library (stating that Browner "lifted a hold on a proposed rule that would give ethanol a larger role in a federal program to fight automobile-induced pollution," permitting rule to be "formally considered" after public comment process). The proposed rule was ultimately published for comment by the Clinton Environmental Protection Agency. See Environmental Protection Agency, Fuels and Fuel Additives: Standards for Reformulated Gasoline, 58 Fed. Reg. 11,722 (proposed Feb. 26, 1993) (to be codified at 40 C.F.R. pt. 80). A modified version of the rule was finalized in 1994. See Regulation of Fuels and Fuel Additives; Standards for Reformulated and Conventional Gasoline, 59 Fed. Reg. 7716 (Feb. 16, 1994) (to be codified at 40 C.F.R. pt. 80).

339 Oil and environmental groups pressed for less ethanol. See, e.g., Oil, Environmental Groups Oppose Ethanol Waiver, Chi. Trib., Apr. 14, 1993, \$3, at 5. Corn growers, on the other hand, lobbied on the side of the earlier Bush administration proposal. See, e.g., Farm Bureau Joins Nationwide Effort for Ethanol Use, PR Newswire, Apr. 29, 1993, LEXIS, News Library (urging filing of comments in Clinton administration rulemaking).

340 See Keith Schneider, Clinton Is Seeking to Increase Role for Ethanol in Gasoline, N.Y. Times, Dec. 15, 1993, at A25.

341 See, e.g., Farm Bureau Joins Nationwide Effort for Ethanol Use, supra note 339 (referring to "program originally proposed by former President Bush" and urging public participation in Clinton administration rulemaking); Oil, Environmental Groups Oppose Ethanol Waiver, supra note 339 (referring to Bush proposal).

342 E.g., Conditions of Participation for Skilled Nursing and Intermediate Care Facilities, 45 Fed. Reg. 47,368, 47,369 (July 14, 1980) (to be codified at 42 C.F.R. pts. 405, 442, 483) (describing "Patients' Rights" and Patient Care Management System provisions); Rich, supra note 21; see supra notes 20-22 (describing attempt to finalize rule).

343 Rich, supra note 21. 
Carter administration proposed that nursing homes be required to assess and plan for individual patient needs, the Reagan administration later introduced a similar concept, but its modifications, meant to give nursing homes more flexibility in how they met the requirement, were specifically discussed in comparison with the Carter proposal. ${ }^{344}$ Moreover, nonprofit groups organized around the Carter proposal, arguing that later Reagan administration actions, even though they did not address precisely the same issues as the Carter proposal, represented a setback. ${ }^{345}$ Their criticism of Reagan proposals to deregulate certain aspects of nursing home operations, such as relaxing survey and certification requirements, specifically made reference to the Carter proposals of two years prior. ${ }^{346}$

Thus, despite its costs for the new President, the contribution made by policy burrowing clearly has benefits under a "presidential control" model of the administrative state. A public policy dialogue that engages a broader array of citizens in a more focused way than during a campaign can result in the agency and the new President receiving a clearer message-perhaps either: "A substantial group of citizenry strongly supports the entrenched rule," or "Citizens view the outgoing administration's policy, compared with alternatives, as useless, expensive, or misguided." Sensitive to reelection prospects, the President thus can transmit any revision in her policy preferences to the administrative state.

Under the other views of agency decisionmaking-either pluralist or civic republican-policy burrowing's contributions to public debate are also likely to have democratic benefits. Under a pluralist view, a process that raises an issue's public visibility, engages the public, facilitates the clearer development of preferences, and allows the agency to discern those preferences obviously will contribute to the agency's

344 See Linda E. Demkovich, Nobody's Happy over Administration's Attempt to Change Nursing Home Rules, 14 Nat'l J. 508, 509 (1982) (comparing "plan of care" provisions in Reagan and Carter administration proposals).

345 Id. at 508 (stating that HHS officials "got into hot water with consumers" by withdrawing Carter regulation guaranteeing patients' rights); Petey Cerf \& Mary Adelaide Mendelson, Letter to Editor, Nursing Homes Need One More Federal Rule, N.Y. Times, Jan. 27, 1982, at A22 (letter to editor from president and secretary of Americans for Better Care referencing Carter rules in discussing Reagan rules).

346 See, e.g., Demkovich, supra note 344, at 508 ("[S]keptics . . . argue [that] the revisions leave only a shell of the 1980 reforms."); id. at 509 (noting that skeptics include National Citizens' Coalition for Nursing Home Reform); Nursing Home Inspections: New Jersey: Hearing Before the House Select Comm. on Aging, 97th Cong. 49 (1982) (statement of Barbara Frank, Director, Information Clearinghouse for the National Citizens' Coalition for Nursing Home Reform) (comparing Reagan administration policy proposals with Carter administration Patient Assessment and Care Evaluation program). 
ability to collect and aggregate public preferences. ${ }^{347}$ Similarly, suppose one conceives of agency decisionmaking as a civic republican process. $^{348}$ A policy debate that engages a more informed general public can help ensure that the agencies are correctly discerning the "values of the entire polity." 349 Or, more broadly, under a view of deliberative democracy such as that advanced by Gutmann and Thompson, such a debate constitutes a highly desirable dialogue, one that involves both the government and the citizens themselves. 350

One might argue that these democratic benefits of late-term rulemaking are overstated, because notice-and-comment rulemaking is already open to all. However, the process is, practically speaking, likely to engage primarily well-organized interest groups-those versed in the intricacies of administrative procedure. ${ }^{351}$ By comparison, a visible public debate more likely would engage less organized segments of the public as well and help assure the agency's fuller consideration of both the diversity of public views and their intensity. Similarly, although the presidential election, too, is open to all and serves to transmit public preferences to agencies, an engaged and focused public debate can offer an agency a more particular sense of public preferences.

For example, compare the case in which the outgoing President has not "burrowed" policy. Here, the agency's value choices in the new administration may be informed only by the new President's preferences-or perhaps by those of the new President and well-organized, narrowly focused interest groups that are proficient at gaining knowledge of and access to administrative decisionmaking processes. The ultimate agency decision in a case like the roadless areas ruleinformed by a more broadly participatory public debate-seems more

347 See Frug, supra note 80, at 1359 (explaining agency decisionmaking as process of aggregating preferences); Stewart, supra note 75, at 1793 (discussing linkage between public attention to policy issue and greater scrutiny of and control over agency policies).

348 Cf. The Federalist No. 10, at 21 (James Madison) (Roy P. Fairfield ed., 2d ed. 1981) (defining deliberation in republic as "refin[ing] and enlarg[ing] the public views, by passing them through the medium of a chosen body of citizens, whose wisdom may best discern the true interest of their country").

349 Seidenfeld, supra note 48 , at 1515 .

350 See text accompanying note 84 ; cf. Bennett, supra note 199 , at 852 (describing "democracy as involvement in conversation" in addition to "vote-centered").

351 The publication of a notice in the Federal Register is likely to have lower visibility than national newspaper coverage. Although well-organized interest groups may well be aware of such proceedings, members of the general public with less informed views may not know of the opportunity to participate. Cf. Pildes \& Sunstein, supra note 257, at 100 ("Education of citizens about the key issues-risk levels and risk comparisons-is at best episodic."); Stewart, supra note 75, at 1806 ("[W]e cannot say that a given litigant or organization truly speaks for 'consumers' unless there is some mechanism that ensures this."). 
likely to be democratically responsive than if the outgoing President had taken no action at all.

It might be argued that the roadless areas rule is something of an easy case for locating policy burrowing's democratic contributions. The outgoing administration was conferring a benefit on a diffuse group-including hikers, others engaged in outdoor recreation, and armchair environmentalists. This group could be assumed to have been underrepresented earlier by organized interest groups and would be highly motivated to engage in public debate because they would be acting to protect something they possessed following the issuance of the rule: an entitlement to pristine national forests.

Certainly a harder case would be the unusual one in which all interested entities were already well organized and well represented. In this case, a burrowed rule might add little to public debate. Another more typical case, however, would be a rulemaking that conferred a benefit only upon a well-organized interest group with diffusely distributed costs upon the public at large. The interest group presumably already would have been aware of and engaged in the administrative decisionmaking process. Further, since it received nothing in the rulemaking, perhaps the general public would be disinclined to participate in a policy debate on whether to reverse the rule, limiting the burrowed rule's potential contribution to public dialogue.

Implicit in this argument is that citizens at large will join in a public debate only if they perceive it threatens an asset they possess, a variant of the "loss aversion" theory of behavioral economists. ${ }^{352}$ While it seems unlikely that people would care nothing about a potential change to the status quo that would create a new benefit, people conceivably could work harder and sacrifice more to protect against

352 The argument also implicitly assumes that to the extent there is underrepresentation in the earlier policymaking process, groups who would obtain diffusely distributed benefits or suffer diffusely distributed costs will be the ones whose interests are underrepresented. Of course, there is a well-known debate, centered on and responding to the work of Mancur Olson, on the conditions under which diffuse groups will organize and represent themselves in the political process. See, e.g., Mancur Olson, The Logic of Collective Action: Public Goods and the Theory of Groups 5-16 (1971); James Q. Wilson, Political Organizations 33-35 (1973) (describing variety of incentives, including solidary and purposive, that may cause individuals to join groups); James Q. Wilson, The Politics of Regulation, in The Politics of Regulation, 357, 366-70 (James Q. Wilson ed., 1980) (detailing circumstances under which groups are likely to organize). The extent to which one can generalize about precisely which groups may have been underrepresented and will benefit from a broader, more visible public debate is beyond the scope of this Article. For my purposes, I wish only to argue that policy burrowing is capable of engaging at least some segments of the public either uninvolved or underrepresented in previous debates on the issue in question. 
the loss of something they already possess. ${ }^{353}$ In theory, then, a new President's revoking a late-term rule that diffusely imposed costs would engender less debate than a rule like the roadless areas one.

On the other hand, unlike, say, winnings in a poker game, a typical setting for behaviorists analyzing these questions, the effects of late-term rulemaking are usually not immediate. In such a case, the identity of the potential "winners"-those with "something to lose" and thus theoretically more likely to participate-is less clear. When the debate over whether to retain the roadless areas rule began, the rule itself had only been announced and was not yet effective. It thus had not yet conferred benefits on the "winners." Further, after the Clinton administration issued its ergonomics rule, which would have instituted workplace safety standards, it was the "losers" under the rule-a broad array of large and small businesses-that organized to effect a repeal. ${ }^{354}$ Thus even if behaviorist-type predictions are taken at face value, a policy debate stirred up by an outgoing administration's late-term rulemaking still seems likely to engage more "losers" and more "winners" among the general public and to prompt them to crystallize and transmit their views to the new administration than if there had been no policy burrowing at all.

Independently, it could be objected that the outgoing administration simply may issue too many rules, making public focus upon each of them impossible and reducing the chances of public dialogue. The outgoing administration intentionally might try to "slip through" rules under the radar screen of the public. However, the time and expense required to promulgate a rule are likely to preclude this as a dominant strategy, instead keeping down the volume of late-term rules. ${ }^{355}$

353 Jeffrey J. Rachlinski \& Forest Jourden, Remedies and the Psychology of Ownership, 51 Vand. L. Rev. 1541, 1544 (1998); cf. Richard Birke, Reconciling Loss Aversion and Guilty Pleas, 1999 Utah L. Rev. 205, 212 ("[P]eople are risk averse when decision making in the face of gains."). But see generally Gregory Mitchell, Why Law and Economics' Perfect Rationality Should Not Be Traded for Behavioral Law and Economics' Equal Incompetence, 91 Geo. L.J. 67, 72 (2002) (arguing that assumptions of behavioral law and economics "cannot lay claim to empirical validity superior to that of the perfect rationality assumption" of law and economics).

354 See infra text accompanying notes $366-69$ (describing ergonomics rule).

355 See, e.g., Sidney A. Shapiro \& Thomas O. McGarity, Reorienting OSHA: Regulatory Alternatives and Legislative Reform, 6 Yale J. on Reg. 1, 3 (1989) (noting that because of budget, resource, and political constraints, "[n]o health and safety agency has been able to promulgate regulations for more than three controversial chemicals in any given year"). To date, late-term rules have been on the order of hundreds, and incoming administrations appear to have succeeded at the task of identifying and reviewing "midnight regulations." See, e.g., Kirschten, supra note 23, at 10 ("Of the 172 'midnight' regulations of the Carter Administration that Reagan froze shortly after taking office, 112 have since gone through without change, 12 have been approved with major revisions, 18 have been withdrawn and 30 remain in limbo as 'still pending." ). However, to the extent rules 
Despite these potential objections, the outgoing President's issuance of the "hard case" rule, one issued in the face of the incoming President's contrary policy preferences, has the potential to increase visibility of particular policy issues and to enhance a public policy debate. While it has democratic benefits, that feature itself raises another objection: For such a rule, like the roadless areas rule, the outgoing administration has the upper hand in setting the policy agenda. Because such a rule binds the incoming administration, it may be compelled to address an issue it otherwise might have let lie and to consider whether there is real public support for the outgoing administration's position. ${ }^{356}$ With respect to late-term rules, the outgoing administration is shifting the burden of inertia to the new administration. ${ }^{357}$

Given the lack of electoral discipline upon its choices, should we be troubled by the outgoing administration's ability to spend public resources to affect the subjects of public debate after its departure?358 By tradition, the new President represents the current majority coalition, possesses executive branch resources, and is thus a major contributor to the national policy agenda. The newly elected President surely should have a "fair chance to work out and apply policies reflecting his objectives." 359 The outgoing administration's actions inevitably impose costs on this ability to control the national policy agenda.

On the other hand, the new President could not (and we would not wish her to) monopolize the national agenda. ${ }^{360}$ As discussed earlier, placing the national agenda completely under presidential control

are "slipped through," greater concern seems warranted. Moreover, for rules exempt from notice-and-comment requirements or policy decisions subject to fewer procedural requirements, an outgoing administration could, of course, slip through a greater volume. These types of decisions might merit greater concern because of both their potentially greater volume and their reduced procedural discipline.

356 The new administration might, of course, also consider the likely ability of opponents to obtain support in Congress or through other means.

357 See Calabresi, supra note 79, at 164 (arguing that judicial actions can appropriately assign "burden of inertia" to legislature to revive anachronistic statute); see also Cass R. Sunstein, After the Rights Revolution: Reconceiving the Regulatory State 158-59 (1990) (advocating search for interpretive principles that will "increase the likelihood of legislative or public correction of outmoded and unjustified norms").

358 Of course, a particular administration always can affect the agenda of later administrations through devices such as rulemaking. The difference presented by agency burrowing is that a President (or agency head) is exercising this power even after an electoral loss.

359 Henry, supra note 179, at 6 .

360 This analysis does assume that the new President is a fairly strong leader, even at the outset of her term. To the extent one assumes that the new President is weak or vulnerable at the outset and needs special room to maneuver and to carry out the will of the electorate, the costs imposed by agency burrowing might be seen as of greater concern. 
might raise the concern of excess control by a majority faction. ${ }^{361}$ In any event, members of Congress and private organizations regularly contribute to the shaping of a national agenda. ${ }^{362}$

As a national leader with her own staff, the departing President also possesses the resources and expertise to identify and develop solutions to issues of public concern. At a minimum, perhaps we should consider an outgoing President's agenda contributions appropriate if she identifies policy goals with significant public support. If we see administrative legitimacy as including a conception of democratic responsiveness, ${ }^{363}$ the outgoing President's agenda contributions might be especially valuable. She is capable of making agenda contributions that represent issues of concern to a substantial minority of the public, one that otherwise might not have a major voice in government. Alternatively, she may identify a concern shared by the majority of voters but not by the President-elect, either because the issue is not a priority for the President-elect or simply because her preferences are different.

Should the electoral loss carry with it a suspicion of the outgoing President's motives? Perhaps we should worry that the outgoing President and her agency administrators will not act out of concern for electoral preferences but perhaps only to serve the President's personal view of the public interest, to benefit the President's campaign contributors or other supporters, or to waste the new President's administrative resources on the elimination of a rule with no real public support.

With regard to comparatively disciplined and public forms of policymaking, such as rulemaking, there seems relatively little cause for concern. As noted, rulemaking requires significant time and budgetary resources. ${ }^{364}$ The number of final rules any administration can make in the last several weeks is inherently limited by resource constraints.

Meanwhile, a President is likely to focus on making rules that will survive the incoming President's administration. She will probably recognize that if she attempts to confront the new President with a policy that lacks public support, the new President will have little political difficulty abandoning it, even if the change comes with substantial administrative costs. ${ }^{365}$ The fate of the November 2000 Clinton

\footnotetext{
361 See supra text accompanying note 267 .

362 See generally Kingdon, supra note 202, at 208 .

363 See supra text accompanying note 79.

364 See supra note 355 (quoting Shapiro \& McGarity).

365 Spence \& Cross, supra note 72 , at 129 ("[W] hen the agency chooses a policy that lies a great distance from [public preferences], interest groups and political entrepreneurs who
} 
administration OSHA "ergonomics rule" might, for example, caution departing Presidents against investing significant resources in a rule not likely to survive. ${ }^{366}$ Opponents criticized the rule as overly expensive, ${ }^{367}$ and its supporters failed to convince Congress to retain it. ${ }^{368}$ It was easily reversed by "fast-track congressional action," and President Bush signed the legislation eliminating the ergonomics rule in March $2001 .^{369}$

\section{c. Personnel Burrowing's Benefits for Internal Agency Deliberation}

In addition to policy burrowing's potential contributions to an enhanced dialogue between the public and the agency, personnel burrowing also can contribute to internal agency dialogue. Despite its potential costs for the President-elect, late-term hiring and promotion potentially can ensure that a range of political viewpoints is represented within the agency, with possible benefits for the quality of agency decisionmaking, its democratic responsiveness, and consequently its legitimacy.

Outgoing administrators engaged in hiring or promotion are likely to prefer individuals who share the views of the outgoing administration and who are especially able to advocate or implement those

oppose the choice will mobilize .. . [ , and may] have a strong incentive to supply voters with more information ...."); cf. Kenworthy, supra note 178 (quoting administration official that it would make "little sense" to issue rules that would be overturned immediately by new administration).

However, if the agency action is a rulemaking that is of interest only to a few, confers benefits on a very narrowly focused group, and imposes costs extremely diffusely, public choice theory suggests that obtaining reversal will be difficult because interest groups, with whom agency regulators will wish to maintain good relations, will strongly oppose a reversal. Cf. Eskridge, supra note 201, at 57 (describing taxonomy of demand for legislation based on distribution of costs and benefits).

To the extent the departing administration issues late-term policy decisions through low-visibility processes other than rulemaking, in the hope that they will "slip through," those decisions might be viewed with more suspicion. See infra text accompanying notes 437-43; supra note 355. In addition to lacking important checks, such decisions might be difficult to reverse as a practical matter if the decision takes the shape of a grant, permit, or another variety of one-time decision. See supra text accompanying note 136.

366 See supra note 135 .

367 See Lizette Alvarez \& Steven Greenhouse, Senate G.O.P. Moving to Nullify Clinton Rules on Worker Injuries, N.Y. Times, Mar. 3, 2001, at A1 (noting that estimates of compliance costs ranged from $\$ 4$ billion to over $\$ 100$ billion).

368 See Steven Greenhouse, House Joins Senate in Repealing Rule on Workplace Injuries, N.Y. Times, Mar. 8, 2001, at A19.

369 See Mike Allen, Bush Signs Repeal of Ergonomics Rule; Administration Promises Business-Friendly Workplace Safety Regulations, Wash. Post, Mar. 21, 2001, at A6. Even if the ergonomics rule had been issued before the end of a presidential administration, it might have fared poorly. The point here, however, is that late-term issuance did not give a leg up to a rule with inadequate public support. 
views. On relatively technical issues, the presence of "impressive" individuals with diverse viewpoints and backgrounds generally will improve the quality of agency decisionmaking. The agency may analyze technical questions more thoroughly, consider a wider range of policy options, and more fully identify potential concerns attending preferred policy options. ${ }^{370}$ The result may be the refinement, modification, and improvement of the ultimately selected policy options. ${ }^{371}$

Moreover, increased political diversity may improve internal agency deliberation not only on technical questions but also on questions of value, enhancing the agency's ability to perceive and respond to public preferences. Of course, agency decisionmaking often implicates questions of value. Take the issue of setting the appropriate standard for arsenic in drinking water. The statute calls on the agency to determine whether the contaminant "may have an adverse effect" on human health. ${ }^{372}$ Even in answering what may appear to be a technical question, however, the agency must consider issues of value, such as how to weigh difficult-to-quantify costs and benefits ${ }^{373}$ or whether, in the absence of reliable information regarding arsenic's risks at a particular level, to take a "precautionary approach" to regulation. ${ }^{374}$

Again, this type of agency decisionmaking takes place against a backdrop of public preferences that may be, at the outset, poorly informed or poorly formed. Even if public preferences on a particular

370 Thomas Merrill describes similar dialogues within the Solicitor General's office between tenured lawyers in that office and attorneys in the litigating divisions regarding whether to confess error in a matter. He argues that the viewpoint represented by the tenured lawyers-to consider the long-term interests of the institution and the value of its reputation for honesty and good faith-would not be represented otherwise if the office were staffed solely by political appointees. See Merrill, supra note 238, at 98-99; cf. Alfred A. Marcus, Promise and Performance: Choosing and Implementing an Environmental Policy 14 (1980) (discussing generally problems of "incomplete information [and] simplistic decision rules" that face agency decisionmakers).

371 See Jon Cannon, Bargaining, Politics, and Law in Environmental Regulation, in Environmental Contracts: Comparative Approaches to Regulatory Innovation in the United States and Europe 39, 68 (Eric W. Orts \& Kurt Deketelaere eds., 2001) (maintaining that diverse culture of EPA personnel deters "adventurous trading at the limits of statutory authority").

372 A primary drinking water standard is to be established if the EPA Administrator determines that the contaminant "may have an adverse effect" on human health, is likely to occur in public water systems, and in the Administrator's judgment, regulation "presents a meaningful opportunity for health risk reduction." See Safe Drinking Water Act Amendments of $1996 \$ 102(\mathrm{~b})(1)$ (A), 42 U.S.C. $\$ 300 \mathrm{~g}-1$ (b)(1)(A) (2000).

373 Cf. Pitkin, supra note 72, at 212 (noting that questions about "what should be done ... involve both facts and value commitments, both ends and means").

374 While Congress does, on occasion, give agencies instructions on such questions, very often the questions are left unanswered in a statute or not answered specifically enough to give the agency concrete guidance. See generally supra text accompanying notes 44,62 . 
issue or for a particular approach (say, stricter environmental regulation) are well formed, they may not have been communicated clearly through the presidential election. ${ }^{375}$ Especially under these circumstances, the presence of entrenched personnel can offer advantages for the agency policymaking process. The range of views held by the electorate are more likely to be reflected among agency policymakers as a group if entrenchment is permitted than if the new President and her political appointees are solely responsible for selecting people to hold positions with significant policymaking responsibility. The agency may bear a closer resemblance to a "mini-legislature," in which the members consider a fair range of public views and interests before settling on one. ${ }^{376}$ This seems to be an acknowledged consequence-as well as a subjective purpose-of late-term hiring and promotion.

Both senior civil servants hired in one administration that continued to serve and political appointees that served with civil servants hired by outgoing administrations have confirmed these advantages in interviews. One high-level civil servant who served in several administrations anonymously expressed her view of participating in a policy dialogue in an administration whose political views did not accord with hers: "I will give the best advice I can. If they want to take it, they can. They won the election, they get to run the government." A Clinton administration political appointee from a different agency commented that viewpoint differences among agency employees helped the quality of consideration of policy options. ${ }^{377}$ A new appointee may find extremely valuable the ability and willingness of a

375 See supra text accompanying notes $262-66$.

376 See, e.g., Pitkin, supra note 72, at 205 (suggesting that those that govern rely on their "wisdom and information to further people's true interests"); Pildes \& Anderson, supra note 327, at 2122-23 (discussing defense of administrative agencies in terms of their resemblance to "mini-legislative assemblies"). In another context, Seidenfeld advocates structuring an agency to guard against "having a dominant set of norms that result in systematically biased outcomes," including by incorporating "staff members with disparate backgrounds in the decisionmaking process." Seidenfeld, supra note 44, at 454; see id. at 489 (arguing to "empower groups within an agency's staff who hold alternative values ... and to encourage agencies to meaningfully involve offices with a variety of backgrounds and roles").

377 Clearly, these advantages will be undermined to the extent that holdovers act subversively. As discussed above, a holdover could fail to identify a policy opportunity for political appointees. Once a policy opportunity is identified, however, political diversity seems likely to improve the agency's consideration of its options. Anecdotally, holdovers largely have stayed loyal to the profession. See, e.g., Light, supra note 251, at 158-59 (stating that political appointees generally find career holdovers to be competent and responsive). 
holdover to engage in an active dialogue on the agency's policy questions. ${ }^{378}$

Finally, individuals that served in earlier administrations can provide institutional memory on policy issues. 379 While institutional memory and the presence of diverse viewpoints within an agency generally may function to moderate its policy positions and legal interpretations, they also serve to retard rapid change and to make an aboutface on a policy approach less likely. Greater policy stability will tend to enhance the agency's perceived legitimacy, both with the public and in the courts. .380

These benefits are, of course, very closely related to the advantages, well-articulated elsewhere, of the American decision to have a career civil service selected independently from the political "spoils system." 381 The principles of such a civil service include not only merit-based selection, but also job tenure, in exchange for which the civil servant is expected both to be committed to the institution and to provide "willing responsiveness to the legitimate political leaders of the day." 382 What an outgoing President's personnel burrowing can add to regular career civil service hiring, however, may be a greater assurance of political viewpoint diversity, especially among civil servants with significant policymaking responsibility. Wood and Waterman argue based on an empirical study that "political appointments dominate the dynamic of institutional control of the bureaucracy." 383 Suppose outgoing political appointees were prohibited altogether from making promotion or hiring decisions that would outlast the

378 See Heclo, supra note 235 , at 215-16 (observing that interviewee called office director "great civil servant" because of willingness to engage in active dialogue).

379 See Merrill, supra note 238, at 95 (discussing "institutional memory" supplied by senior civil servants).

380 See Christensen v. Harris County, 529 U.S. 576, 587 (2000) (noting relevance of agency consistency to Skidmore test of deference to agency legal interpretations); Krehbiel, supra note 201, at 230-31 (noting advantages of "stable regulatory environments" and that "many actors outside of government, while not perfectly satisfied with somewhat off-center policies, nevertheless prefer a known and stable policy regime").

381 See, e.g., Skowronek, supra note 234, at 178-210 (describing creation of civil service in response to "spoils system" and gradual increase in merit-based hiring of civil servants).

382 Heclo, supra note 235, at 20; see also id. at 21 (commenting that civil servants are responsible to political heads and have responsibility that is "institutional and enduring"); id. at 220 (asserting that civil service was created to institutionalize "continuous capacity to offer honest advice"); Merrill, supra note 238, at 93 (arguing for "institutional capital" justification for placing civil servants in high level positions and arguing further that career civil servants may implement more policy more evenhandedly).

383 See Wood \& Waterman, supra note 33, at 73 (contending that "outputs shifted" after new political appointments in six of eight federal agency programs and that, generally, "political appointments dominate the dynamic of institutional control of the bureaucracy"). 
presidential term and that new political appointees made all such appointments. Given the turnover that frequently accompanies a presidential transition, and because of the desire to avoid the monitoring costs described above, a new President would have a strong incentive to select high-level career agency officials that have similar personal political views or a high degree of personal loyalty. The risk: Among high-level agency policymaking officials, both career and political, the President's value preferences might dominate. ${ }^{384}$

Greater internal diversity can benefit agency decisionmaking whether one thinks of the administrative state as a civic republican institution ${ }^{385}$ or more pluralist in nature. Effective deliberation within a civic republican institution requires the representation of a wide range of viewpoints within the discussion, enabling the participants' preferences to crystallize "during the very course of the decisionmaking process." 386 Personnel burrowing can help address significant risks inherent in agency decisionmaking from the standpoint of civic republican theories: the failure to consider key viewpoints within the deliberative process and the related risk of agency capture or bias. ${ }^{387}$

384 There might be an argument that after burrowing, an agency might "tilt too far" away from the President's views, so that rather than increasing political diversity, burrowing might reduce it. While conceivable, this seems unlikely in view of the seniority and the authority possessed by presidential appointees in the agencies. See supra note 383 . "Burrowing in" office directors or civil servants at lower levels seems more likely to serve as a counterbalance.

385 Cf. Seidenfeld, supra note 48, at 1555 (noting that discussion among agency staff offices with differing viewpoints is most likely to result in policy that serves "more universal consensus of the common good").

386 Croley, supra note 127 , at 78 .

387 See id. at 77 (remarking that civic republican theory is "nebulous with respect to exactly who participates in regulatory decisionmaking and, though less so, about what the behavioral motivations of those participants are"); Steven Kelman, Adversary and Cooperationist Institutions for Conflict Resolution in Public Policymaking, 11 J. Pol'y Analysis \& Mgmt. 178, 183 (1992) (considering tendency of majoritarian institutions to undervalue minority concerns); Note, Civic Republican Administrative Theory: Bureaucrats as Deliberative Democrats, 107 Harv. L. Rev. 1401, 1410 (1994) (arguing that civic republican theory fails to come to terms with tension between deliberation and need for public participation). For example, Seidenfeld notes the troublesome "propensity of agencies to marginalize the values of those outside the political mainstream." Seidenfeld, supra note 48 , at 1558; see, e.g., Ayres \& Braithwaite, supra note 127, at 18 (stating that effective civic republican deliberation may require "organizational empowerment of disorganized constituencies"); Seidenfeld, supra note 48 , at $1568-70$ (discussing need for internal competition to combat risks of capture and noting that government may have to fund some interest groups or offer especial encouragement).

I do not attempt to argue that agencies will be better at selecting policy than Congress, though this could be so where an issue is highly complex and technical in nature. $\mathrm{Cf}$. Mashaw, supra note 46, at 98-99 (claiming that total error and decision costs may be lower when agency, rather than Congress, decides certain questions). My point is simply that given a broad statutory delegation of lawmaking authority to an agency, greater political 
Even though the number of people that remain in high-level policymaking positions from an earlier administration is likely to be relatively small after personnel entrenchment efforts, outgoing administrations very often select or promote these individuals because of their intellectual or managerial talents. Consequently, they may well be effective advocates for a minority viewpoint. ${ }^{388}$

Even if agency decisionmaking is conceived of as assembling an array of external preferences, as under a pluralist approach, internal political diversity also offers advantages. Decisionmakers act as "conduits" for private preferences, gathering their preference information from interest groups or through the expressive function of the national presidential election. ${ }^{389}$ The legitimacy of the ultimate agency decision turns on the representation of a "wide variety of affected interests" within the administrative process. ${ }^{390}$

However, interest groups cannot, of course, represent public preferences adequately if those preferences are not well formed or well informed. Even if public preferences are clear, some interests nonetheless may not be fully represented before agencies, ${ }^{391}$ or agency employees may have a tendency to respond to some interests more than others (perhaps because of the need for information or political support). ${ }^{392}$ Without the ability to aggregate public preferences meaningfully to select an appropriate social policy, agency policymakers will have to rely on information and arguments they can collect from interest groups or upon their own views of the "public interest." ${ }^{393}$ Under

diversity within the agency is likely to yield a better deliberative process and a better policy outcome.

388 The case could be different if the "burrowed" personnel are motivated by the desire to distribute rents to private interest groups-in other words, if they were "captured." In that case, they might add little to the internal agency dialogue and might, moreover, impose even greater monitoring costs upon the new President. However, individuals seem relatively unlikely to extend their government service into a new administration as a means of improving their chances at a private sector position, the motivation hypothesized by public choice theorists. See supra notes 226-27 and accompanying text. Moreover, as Spence and Cross argue, "agency capture is no longer regarded as a valid descriptive theory of bureaucratic behavior." Spence \& Cross, supra note 72 , at 121-22. They rely on evidence that regulated interest groups are "not confident of their prospects in the agencies themselves." Id. at 123.

389 See Croley, supra note 127 , at 58 ; Spence \& Cross, supra note 72 , at 113 (arguing that electoral accountability results in voter values corresponding reasonably well to politician values); Stewart, supra note 75, at 1670 (noting that "function of administrative law is ... to ensure the fair representation of a wide range of affected interests in the process of administrative decision").

390 Stewart, supra note 75 , at 1670.

391 Of course, public choice theories predict other limitations on the effectiveness of interest groups in representing various interests. See supra note 352.

392 See Stewart, supra note 75 , at $1776-77$.

393 See supra note 376 (quoting Pitkin regarding use of "wisdom" by those that govern). 
these circumstances, internal political diversity will tend to blunt agency biases toward one interest group or another and to improve the quality of the deliberation.

Similarly, if one adopts the "presidential control" view of the administrative state-seeing agencies primarily as the President's agents-greater internal political diversity can ensure that the President and her appointees take account of a wider range of views in developing and selecting policies. The ultimate policy decision is likely to be better refined and more responsive to a wider array of preferences even if the President is conceptualized as the decisionmaker.

Implicit in these arguments is an assumption that "entrenched" civil servants' contributions to agency deliberations or presidential decisionmaking will be motivated by professional goals and a desire to serve the public interest ${ }^{394}$ rather than by private rent-seeking motivations. As an empirical matter, this seems plausible, as discussed above. 395 But even if a particular "entrenched" civil servant merely wants a good private sector job upon departing government and has stayed on in order to express views that are intended to distribute rents to well-organized private groups that could, in the future, employ her, her view as expressed in deliberation will be one among many and may well be offset by others. ${ }^{396}$

\section{Contributions to Agency Accountability}

Besides offering benefits for public dialogue and for internal agency dialogue on policy questions, agency burrowing can increase the extent to which agencies are governed by the rule of law and are required to account for their actions to outside institutions. Burrowed personnel may serve as monitors and increase available information about agency conduct. Further, the desire to entrench policy may prompt an agency to devise legally binding rules that cabin its own discretion.

394 While one theoretically could draw a distinction between a civil servant's serving a Burkean idea of the public interest and the civil servant's service of the actual public interest as the bureaucrat sees it, see Levine \& Forrence, supra note 72, at 178 (discussing Burkean interests), this distinction may be very difficult to draw where there is no crystallized public view on a particular issue.

395 E.g., supra notes $226-27$ and accompanying text.

396 But see generally supra text accompanying notes 226-27 (assessing persistent risk of subversion accompanying personnel burrowing). 


\section{a. Improved Monitoring}

While entrenched personnel can increase costs for a new President who wishes to ensure the execution of her preferred policy preferences, ${ }^{397}$ entrenched personnel also can serve as monitors of agency performance. By supplying information about agency activity, these monitors can assist other institutions in holding agencies accountable for their actions and can reduce concerns about abusive or "captured" agency action.

As a general matter, agency performance is difficult to monitor. For example, depending on how you count, there are over fifty federal agencies, with over a million federal employees. ${ }^{398}$ While Congress has considerable power to monitor, including through the use of subpoena power and the threat of reductions of appropriations, it is hampered by resource constraints and a lack of information about the details of agency activity. ${ }^{399}$ Moreover, as discussed above, Congress may pursue issues for oversight on a relatively ad hoc, fragmented basis. ${ }^{400}$ Similarly, it is difficult for voters to assess internal agency activities. Although anyone can request agency documents under the Freedom of Information Act (FOIA), agency backlogs in processing FOIA requests are notorious, and the public may lack the in-depth expertise necessary to evaluate agency documents once they receive them. ${ }^{401}$

Nor are the President and her political appointees likely to be able to fill the monitoring gap completely even under the best of circumstances. ${ }^{402}$ Not surprisingly, "the President and Vice President are in fact ordinarily too busy to play a direct role in regulatory poli-

\footnotetext{
397 See supra text accompanying notes $239-51$.

398 See U.S. Gen. Accounting Office, GAO/GGD-97-72, Staff Study: The Excepted Service: A Research Profile 12 tbl.1.2 (1997) (reporting 1.7 million employees in "executive departments" and another 1 million in "independent agencies," which includes for purposes of report all agencies without representation in President's cabinet). The same report states that the executive office of the President employs approximately 1500 individuals. Id.

399 See, e.g., Laffont \& Tirole, supra note 226, at 501 ("Political principals . . . are at the mercy of better-informed agencies."); id. at 502 (discussing difficulty of monitoring "millions of bureaucrats").

400 See supra notes 47-49 and accompanying text.

401 See generally Office of Info. \& Privacy, U.S. Dep't of Justice, FOIA Post: Summary of Annual FOIA Reports for Fiscal Year 1999, http:/www.usdoj.gov/oip/foiapost/2001foia post 17.htm (last visited Apr. 8, 2003) (describing Freedom of Information Act (FOIA) backlogs by agency and noting that median number of days that FOIA requests were pending ranged from 12 to 758 depending on agency).

402 Seidenfeld, supra note 48, at 1569 ("No matter how great the President's authority to dictate agency policy, the breadth and complexity of agency action exceeds any one individual's monitoring capacity. The President might be able effectively to monitor a few salient policies, but would have to delegate virtually all of the responsibility for monitoring
} 
cymaking." 403 And assuming (despite the fact that they are unelected) that monitoring by political appointees could substitute for presidential monitoring, political appointees constitute a relatively small proportion of agency employees. ${ }^{404}$ Consequently, the President and her political appointees may find it costly to get the information necessary to monitor the agencies. ${ }^{405}$

By comparison, agency employees with diverse ideological views or without special personal loyalty to the sitting President ${ }^{406}$ can serve as decentralized monitors of agency activity. ${ }^{407}$ Agency employees are uniquely positioned to know and evaluate agency activities. At least some may be motivated to serve as monitors of agency conduct, including the conduct of political appointees, by a sense of professionalism, a commitment to the institutions they serve, or the desire to act in the public interest. 408 Further, they are in a special position to provide information to White House staffs, congressional staffs, and the media. Civil servants regularly have informal relationships with congressional staff in addition to the more formal relationships between

others."); see also Laffont \& Tirole, supra note 226, at 502 ("Elected officials often lack the competence, the time, and even the incentive to carefully scrutinize agencies.").

403 McGarity, supra note 47, at 1431; see also Seidenfeld, supra note 46, at 14 (noting that OMB lacks both "personnel [and] resources ... necessary to analyze independently most agency proposed rules").

404 See U.S. Gen. Accounting Office, GAO/GGD-92-101FS, Fact Sheet for the Chairman, Subcommittee on Civil Service, Committee on Post Office and Civil Service, House of Representatives: Political Appointees: Number of Noncareer SES and Schedule C Employees in Federal Agencies 4-5 (1992) (documenting that political appointees in September 1991 totaled 2435); supra note 398 and accompanying text (reporting on total federal civilian employment); see also Heclo, supra note 235, at 214 (describing organizational difficulty of presidential governing through outside placements); Seidenfeld, supra note 44 , at 485-86 (explaining difficulty faced by President and close aides in monitoring agency decisions).

405 Wood \& Waterman, supra note 33, at 9 (discussing ineffectiveness of presidential supervision); Seidenfeld, supra note 46, at 14 (finding that presidential monitoring functions often must be delegated to "low-level staff members whom the President may not know at all").

406 This is not to suggest that agency employees might be actively "disloyal" to the sitting President, but that they might be sympathetic to a variety of other policy preferences than those preferred by the President or that they may be more loyal to the institution of the President rather than to the individual that occupies that office. See, e.g., Merrill, supra note 238, at 98-99 (arguing that career attorneys at Office of Solicitor General may be loyal to institution of President).

407 Cf. Laffont \& Tirole, supra note 226, at 612 (describing argument that Congress's oversight role consists of creating "decentralized system" where individual citizens and organized groups can examine administrative decisions and seek remedies (citing McCubbins \& Schwartz, supra note 49, at 166)).

408 See, e.g., Stewart, supra note 75, at 1715 ("In practice, the professional zeal of administrators ... may frequently check or reverse tendencies toward bias in agency policy."); see also Heclo, supra note 235 , at 21 (noting "institutional" obligations of civil servants). 
Congress and the secretary of a department or the administrator of an agency, relationships civil servants generally wish to maintain. ${ }^{409}$ Consequently, civil servants with some sense of independence from the sitting President are in a position to bring agency activity to the light of day. ${ }^{410}$

In a recent and well-publicized example, Coleen Rowley, a senior civil servant who had served in multiple administrations prior to serving under President George W. Bush, ${ }^{411}$ exposed shortcomings in the Federal Bureau of Investigation's procedures that led to inadequate investigation of the computer files of the "twentieth hijacker," Zacarias Moussaoui, prior to the September 11, 2001, hijackings. Ms. Rowley suggested that political appointees, deliberately or not, tried to obscure the mistakes that were made. ${ }^{412}$ Further, civil servants at the EPA were the ones to disclose the ethical and legal violations of Administrator Anne Gorsuch Burford and Assistant Administrator Rita Lavelle in the Reagan administration. ${ }^{413}$

409 See, e.g., Heclo, supra note 235, at 146-47 (declaring that desire to preserve informal long-term relationships may result in "less than lockstep" institutional loyalty); Mashaw, supra note 50, at 128 (recounting comment of FDA general counsel: "I hope I've been allowed to see all the FDA internal memoranda that Senator Kennedy has").

410 See James P. Pfiffner, The Strategic Presidency: Hitting the Ground Running 82 ( $2 \mathrm{~d}$ ed. 1996) ("[W]e would expect career bureaucrats to resist any orders to allocate grants based on illegal or political criteria ... [and to] blow the whistle rather than to cover up illegal activities by their colleagues or political superiors.").

411 It could be argued that Ms. Rowley and the other individuals that took action in these examples were not employees that "burrowed in" at the end of a presidential administration. Nonetheless, the example illustrates that a workforce that is ideologically diverse or that does not have special loyalties to the current President can function as a check on inappropriate use of agency discretion. Personnel burrowing will tend to increase the independence of the agency workforce.

412 See Romesh Ratnesar \& Michael Weisskopf, How the FBI Blew the Case, Time, June 3, 2002, at 24, 26 (summarizing Rowley allegations); James Risen, F.B.I. Agent Says Superior Altered Report, Foiling Inquiry, N.Y. Times, May 25, 2002, at A10 (same).

413 See, e.g., David Burnham, Tension Bubbles in the Bureaucracy, N.Y. Times, Mar. 13, $1983, \S 4$ (Week in Review), at 2E (describing involvement of career engineer in EPA scandal). The Burford/Lavelle scandal, one of the biggest government scandals of the Reagan years, centered around allegations that the EPA's Superfund hazardous waste cleanup program was tainted by conflicts of interest and managed for political purposes. The administration was alleged to have covered up its misconduct by refusing to provide documents to Congress. Both Burford and Lavelle left the agency, in addition to several other high-level EPA officials, and Lavelle was convicted of perjury. See generally The EPA Dispute in Brief, N.Y. Times, Mar. 10, 1983, at B12; Chronology of Events in the E.P.A. Dispute, N.Y. Times, Mar. 10, 1983, at B12. See also Cannon, supra note 371, at 68 (discussing participation of those "sensitive to the rule of law" in EPA dealmaking with regulated entities). In another example, Gifford Pinchot, the chief of the Forest Service serving under President Taft, contacted Congress directly to encourage it to investigate the Interior Department's management of Alaskan coal reserves. See Skowronek, supra note 234, at 190-91 (concluding that despite his ultimate firing by Taft, Pinchot's intervention spawned congressional oversight and ultimate resignation of Interior Secretary). 
During the present administration, some EPA officials who also served in previous administrations have made clear their disagreement with the White House's "Clear Skies" initiative to cut back airquality enforcement actions against public utilities and replace them with an emissions trading system. These officials apparently disclosed documents, including internal agency documents, which show arguably improper influence on administration policymaking resulting from contacts with energy industry lobbyists. ${ }^{414}$

As with the Rowley and "Clear Skies" examples, sometimes these types of disclosures not only may give information to monitoring institutions, such as Congress, but also may constitute a subversive "leak" in the eyes of an agency administrator. Of course, the potential is there for an agency to be incorrectly charged with laziness or wrongdoing, perhaps by a disgruntled employee. Further, concerns about selective or out-of-context disclosures from agency discussions might result in those discussions being more tightly controlled.

On the other hand, political appointees interviewed for this Article have observed that the presence of individuals who have worked for earlier administrations deters political appointees from approving government grants or making policy decisions that might present even an appearance of favoritism. ${ }^{415}$ The presence of individuals inside an agency who are perceived to have different political values and allegiances clearly can keep political appointees on their toes and serve as a deterrent to agency behavior that smacks of corruption or capture. ${ }^{416}$

A diverse and professional career civil service could, of course, supply these types of monitoring benefits-and these sorts of benefits regularly have been claimed for the career civil service. ${ }^{417}$ What personnel burrowing can potentially contribute, however, is greater assurance that the career civil service does indeed contain within its ranks able individuals with significant policymaking responsibility and diverse political views.

414 See supra note 244 (discussing document disclosure).

415 Of course, these "holdover" individuals may not have been hired or promoted by a departing administration specifically in anticipation of a new President's arrival. However, burrowing is likely to help ensure that the agency is politically diverse even after the new President has completed her appointments and hiring.

416 Cf. Ayres \& Braithwaite, supra note 127, at 56 (arguing for empowerment of public interest groups as "fully fledged third player" to ensure agency accountability).

417 See, e.g., Heclo, supra note 235, at 240 (noting civil service system designed to safeguard integrity of government institutions from abuse). 


\section{b. Greater Policy Transparency and Stability Through Creation of Administrative Limiting Rules}

The advantages of an agency adopting administrative limiting rules-binding rules that limit its own discretion-are well-recognized. First, the use of such rules provides regulated entities with greater certainty; they can have more reliable expectations about how government programs affecting them will operate. ${ }^{418}$ Second, because these rules are legally binding, affected parties can invoke the jurisdiction of the courts to require agencies to comply with them. Private parties can hold the government to its word-"normatively, a desirable state of affairs." 419 The creation of these rules makes an obvious contribution to the rule of law governing agencies and increases the extent to which an agency can be held accountable for its exercise of authority.

Third, the notice-and-comment procedures generally required to issue a legislative rule offer their own advantages. An agency must develop its policy analyses and decide policy questions in a relatively disciplined and transparent way, providing opportunities for public participation. Whether one takes a pluralist, civic republican, or presidential control view of the administrative state, requiring the government to publicize and explain its reasons enhances the legitimacy of the government's decision. ${ }^{420}$

Finally, due both to the significant analysis that generally must accompany rulemaking, as well as its cost, these rules, once created, are likely to last, making agency policy decisions more stable. ${ }^{421}$ Sta-

418 See, e.g., Strauss, supra note 65, at 1.476 (describing how Nuclear Regulatory Commission rules inform manufacturers of nuclear facilities).

419 Id. at 1465. See generally Lowi, supra note 46, at 125-56 (discussing "patholog[y]" of delegation to administrators without "guides, checks, safeguards" and need for rule of law).

420 See Michael Asimow, On Pressing McNollgast to the Limits: The Problem of Regulatory Costs, Law \& Contemp. Probs., Winter 1994, at 127, 128 (noting that rulemaking procedures help legitimate use of agency authority and promote values of "accuracy, efficiency, and acceptability"). As Jerry Mashaw points out, increased process transparency and decision rationality both can "protect rights and limit government" under a liberal view of government, and "assure access and an appropriate accommodation of interests" under a pluralist viewpoint. Mashaw, supra note 50, at 115. Gutmann and Thompson similarly argue that "publicity" is essential to a well-functioning deliberative democracy. See Gutmann \& Thompson, supra note 84 , at $100-01$ (maintaining that making reasons public is necessary for deliberation to occur, helps secure consent, and helps create atmosphere of mutual respect); cf. Jonathan T. Molot, Reexamining Marbury in the Administrative State: A Structural and Institutional Defense of Judicial Power over Statutory Interpretation, 96 Nw. U. L. Rev. 1239, 1313 (2002) (arguing that judicial legitimacy "might flow from the accessibility [and transparency] of judicial reasoning").

421 The rulemaking process has been criticized as overly expensive, leading agencies to avoid it even when a policy should be changed. See supra note 65 (summarizing commen- 
bility generally tends to make government more consistent and predictable for individuals, ${ }^{422}$ consequently giving individuals the sense that they are subject to a legitimate government-one governed by the rule of law. 423 By comparison, even if they might withstand judicial review, frequent policy "flip-flops" may well be perceived publicly as capricious, and the use of rulemaking, with its attendant administrative costs, procedural requirements, and openness to judicial review, will tend to deter such policy flip-flops.

As Part II discusses, agencies often avoid this type of procedure for making broad policy decisions, both because an agency (or the President) may wish to retain discretion and because rulemaking consumes time and resources. Under the more flexible, less formal, and nonbinding policies that result, however, holding the agency accountable for a policy decision can be quite difficult. One example is the policy decision (or decisions) at issue in Lujan v. National Wildlife Federation.${ }^{424}$ The central issue in the case as it reached the Supreme Court in 1990 concerned an initiative within the Bureau of Land Management (BLM), apparently beginning in 1981,425 to revisit the classification of public lands that had been "withdrawn" from multiple uses such as mining and timbering. One of the BLM's internal manuals,

tary on rulemaking "ossification"). In addition, the use of a rule can result in loss of flexibility to address unforeseen individual circumstances. See, e.g., Seidenfeld, supra note 44, at 440 (noting that agencies "often cannot alter rules on short notice to take into account the latest understanding ... or unforeseen circumstances"). Mashaw argues that greater flexibility is an advantage of congressional delegation of policy decisions to agencies and that agencies may use that flexibility to particularize just results to the individual's case. See Mashaw, supra note 46 , at 86 (emphasizing "equal importance of a contradictory demand: the demand for justice in individual cases"). See generally Louis Kaplow, Rules Versus Standards: An Economic Analysis, 42 Duke L.J. 557, $597-99$ (1992) (comparing desirability of detailed rules with nonspecific standards in variety of settings). Admittedly, greater use of rulemaking necessitates a loss of flexibility on the agency's part. To the extent that the agency would have used its flexibility to design "just" results in individual cases not foreseen at the time of the rulemaking rather than to serve less respectable goals, there obviously will be some cost to fairness and good public policy. However, even after using the rulemaking process, the agency still is likely to have greater flexibility to change its policy than would Congress. See Mashaw, supra note 46, at 96 (concluding that policymaking by administrative rule avoids need for administration to "negotiate with [] Congress for changes in policy").

422 See Eric A. Posner \& Adrian Vermeule, Legislative Entrenchment: A Reappraisal, 111 Yale L.J. 1665, 1672 (2002) (listing institutions that contribute to stability and predictability of government).

423 Cf. Strauss, supra note 71 , at 845 (arguing that agencies should follow precedent because of rule of law concerns and "the consistency and predictability of the legal framework over time").

424497 U.S. 871 . (1990).

425 See Nat'l Wildlife Fed'n v. Burford, 676 F. Supp. 271, 273 \& n.1 (1985) (noting that "most if not all of the contested terminations occurred since January 1, 1981" and granting preliminary injunction against modification of land use designations in effect on that date). 
for example, contained the following instruction to agency managers regarding the "withdrawal review" program:

A BLM or other-agency manager recommending that lands not be opened to multiple use, particularly mining and mineral leasing, must convince the BLM Director, Secretary, and watchful segments of the public, that there is no reasonable alternative to continued withdrawal or classification. Occurrence of special or unique flora, fauna, wilderness, or cultural resources on a tract ... do not justify delay in revoking or modifying a withdrawal made for some other purpose. ${ }^{426}$

The emphasized language suggests that the BLM had in fact adopted a policy regarding the circumstances under which a withdrawal would be revoked; the presumption would be in favor of greater use, including mining, rather than use restriction, and an employee recommending continued withdrawal would bear a heavy burden of justification.

A number of environmental organizations attempted to challenge the BLM land withdrawal review program. At the time the lawsuit reached the Supreme Court, the BLM had made over a thousand individual classification terminations and withdrawal revocations. ${ }^{427}$ In part due to the extremely large number of individual classifications relevant to the suit, the Supreme Court declined to find that there was any single "agency action" embodying the programmatic policies for which review could be sought. ${ }^{428}$

The internal manual language quoted above appears to state the agency's approach to exercising its discretion over public lands classification. Had that language been embodied in a legislative rule issued by the BLM, rather than in an internal manual, there would have been a final agency action eligible for judicial review. ${ }^{429}$

We cannot make assumptions about the content of the policy had the agency used rulemaking to issue it. ${ }^{430}$ However, the agency would

426 Bureau of Land Mgmt., U.S. Dep't of the Interior, BLM Manual \$2355.31 (1982) (on file with the New York University Law Review) (emphasis added); see also Brief for Respondent at 4, Lujan (No. 89-640) (describing BLM guidance manual).

427 See Lujan, 497 U.S. at 890.

428 Id. . But see id. at 913-14 (Blackmun, J., dissenting) ("In one sense, of course, there is no question that a 'program' exists.").

429 See, e.g., 5 U.S.C. $\$ 551$ (2000) (defining "agency action" to include agency "rule" or "order"); $\$ 704$ (authorizing judicial review of "final agency action"). Of course, the action would have to be brought by a plaintiff with standing, and courts still might decline, on ripeness grounds, to review the rule until its application in a particular case. E.g., Abbott Labs. v. Gardner, 387 U.S. 136, 152-54 (1967).

430 But see Brief for Respondent at 8, Lujan (No. 89-640) (arguing that if agency had followed "statutory and regulatory scheme," "the results of the land withdrawal review process almost certainly would have been different"). 
have used a more disciplined process to develop the policy. The agency would have used notice-and-comment rulemaking to develop the policy, would have had to articulate a justification in favor of the criteria it was applying, and would have been required to provide an opportunity for public participation. The agency also would have been more accountable for its exercise of authority over public lands; the agency would have subjected itself to judicial review, both to potential challenges to the rule and to its failure to act in conformity with it.

The BLM's decision not to use rulemaking to describe its withdrawal review program, but instead to rely on an internal manual, may have been motivated, like many such decisions, by the general wish of a President or agency head to maintain flexibility in implementing a statutory program. The agency might thereby have avoided the administrative costs of issuing a policy in the form of a legislative rule and the potential costs that might accompany change or deviation from that policy. ${ }^{431}$

At the end of a presidential term, however, that incentive to retain flexibility and discretion appears to be offset by the desire to entrench policy into the next administration. That can lead an agency to use rulemaking rather than less formal methods of policy setting, ultimately contributing to agency accountability and the rule of law. This also can be seen in detail in the roadless rule. Consider the state of affairs before the rule's promulgation. Road-building decisions took place on a forest-by-forest basis through the forest planning process and through permit application decisions made by forest supervisors. To the extent road-building was disfavored (or favored), that policy could be accomplished simply by superiors encouraging forest supervisors not to approve (or to approve) new roads. This type of informal supervision grants superiors, including political appointees, freedom to respond flexibly to changing values relating to, say, whether particular forest resources should be harvested and sold or whether a particular forest should be preserved untouched. But this approach also is relatively opaque to outside observers, potentially could result in inconsistent policies across national forests, and provides individual forest service employees with a standard that contains significant slack.

The Clinton administration rule purported to remove this discretion from individual forest-level or district-level supervisors and to establish a binding rule that generally would preclude roads in these roadless areas. Even under the announced Bush administration

431 See supra text accompanying notes 151-61, 192-208. 
change in approach, the Clinton administration roadless rule still succeeded in changing a background assumption about road-building. Absent a new process of reconsideration on a forest level, roads will not be built in roadless areas. Moreover, the considerations explicitly identified in the roadless area rule-preserving these relatively pristine parcels of land for posterity-are likely to continue to influence Forest Service decisionmakers.

Leaving aside whether one agrees with the policy embodied in the Clinton administration rule, it is an improvement from the perspective of agency accountability. ${ }^{432}$ To issue the Clinton administration roadless areas rule, the Forest Service had to develop its policy in a relatively more public, more disciplined, and more transparent way: The agency's use of notice-and-comment rulemaking required the agency to declare its proposed policy publicly, give a public accounting of its reasons for issuing the particular rule, and to do so in a process providing opportunities for public participation. All this was more transparent (and more binding upon the agency) than the process of developing an unpublished guidance or amending the Forest Service Manual. The rule further offered the prospect of judicial review, both of the rule itself and, more critically, of later agency conduct. The threat of judicial review of agency conduct against the more detailed decision criteria provided by the rule could serve to deter arbitrary, inconsistent, or abusive agency decisions. ${ }^{433}$

The EPA's commitment, by rule, to set certain types of water pollution standards (TMDLs) in the event of a state's failure to do so is another example. As discussed above, the EPA had for decades re-

432 Of course, the promulgation of a binding national rule has costs: It will, for example, result in some loss of flexibility to address particular local situations not anticipated by the rule. See supra note 421 (noting that agency rulemaking leads to administrative loss of flexibility but that it compares favorably to enactment of statutory rule).

433 See Seidenfeld, supra note 46 , at 24 (suggesting that agencies, especially at professional level, take seriously judicial pronouncements to "act deliberatively and consider all relevant factors"). Of course, the availability of judicial review may be limited to plaintiffs with proper standing. See, e.g. Spence \& Cross, supra note 72, at 140 (arguing that, in part due to standing limitations, courts can be "readily manipulated" by special interest groups). Moreover, it could be argued that both "arbitrary and capricious" review under the Administrative Procedure Act and review of questions of law under the Chevron doctrine are too deferential to strictly constrain agency conduct. See generally text accompanying notes 58-61. But see Bressman, supra note 46, at 1401-02 (discussing AT\&T v. Iowa Utilities Board, 525 U.S. 366 (1999), as imposing burden of detailed explanation upon agency under Chevron). Nonetheless, the availability of judicial review at least in some cases, and the implicit requirement that an agency assemble a record in defense of a policy decision, clearly deters abusive and irrational agency conduct. See, e.g., McGarity, supra note 47 , at 1452 (observing that prospect of substantive judicial review can be "great hedge against arbitrariness"); Seidenfeld, supra note 44 , at $458-59$ (noting "indications that expost review helps curb documented abuses of the regulatory system"). 
served its discretion to set those standards on an ad hoc basis. ${ }^{434}$ Through the rule, however, the agency publicly committed to set the standards and allowed itself to be held accountable in court for doing so.

In addition to publicly committing to apply its discretion in a particular way, the agency that issues a rule like the TMDL rule also imposes a heightened procedural obligation on the next administration. Should the agency, operating under a new administration, wish to change the policy or return to a more flexible state of affairs, it too will be committed to do so through rulemaking. That requires the agency to afford some opportunity for public participation and to publicly present the decision criteria it wishes to apply and the policy choices embodied in those criteria, or at least its reasons for retracting the decision criteria selected by the previous administration. ${ }^{435}$

Of course, an agency could develop an administrative limiting rule at any time. However, as discussed above, the strong tendency is for agencies to use more readily changeable and nonbinding forms to set policy. ${ }^{436}$ In contrast, the late-term desire of an outgoing presidential administration to "entrench policy" can contribute a valuable incentive for an agency to self-regulate, as the Forest Service did with the roadless rule.

\section{Policy Entrenchment Other Than Rulemaking}

The positive consequences of late-term rulemaking discussed above flow largely from a few features: First, rulemaking itself is a comparatively disciplined and transparent process for setting policy; second, it generally results in legally binding criteria limiting the agency's discretion; and third, it increases the likelihood that the public will be engaged in a policy dialogue, which in turn could inform the new administration's ultimate policy choice and make it more democratically responsive. Any of these features alone would seem to contribute to the legitimacy of the administrative state: its democratic responsiveness, its accountability to outside institutions (including

434 See supra text accompanying note 190.

435 See McGarity, supra note 47, at 1444 (stating that requirement for reasoned explanation "can be an effective and relatively inexpensive curb on arbitrariness"). For example, the current proposal to withdraw the TMDL rule publicly articulates in significant detail the agency's reasons for considering a change in policy. See Withdrawal of Revisions to the Water Quality Planning and Management Regulation and Revisions to the National Pollutant Discharge Elimination System Program in Support of Revisions to the Water Quality Planning and Management Regulation, 67 Fed. Reg. 79,020, 79,022-26 (proposed Dec. 27, 2002) (to be codified at 40 C.F.R. pts. 9, 122-24, 130); see also supra note 191 (noting final rule was issued to accomplish withdrawal).

436 See supra text accompanying notes $65-71,183-85$. 
through the rule of law), or both. Our cautious assessment of policy burrowing should take into account not only its costs for the new President, but also these contributions to the administrative state.

However, we might view other forms of late-term policy entrenchment, which lack these features, with greater caution. Not all policy actions share the procedural discipline and legally binding quality of a legislative rule.437 Nor do they have the same likelihood of enhancing a public policy dialogue. The broader in effect the policy action, the more likely it will engage a variety of public groups and enhance public dialogue on the issue. ${ }^{438}$ The late-term issuance of a legislative rule may not generate a broader public dialogue, if, for example, the rule is on a subject of interest only to a very few. ${ }^{439}$ Other forms of policy entrenchment may lack significant potential to create dialogue, and, moreover, because of their lack of procedural discipline and their narrow focus, coupled with the lack of electoral accountability, they may present a greater risk of abuse.

Consider the issuance of grants or the setting of the terms of a relatively limited grant competition. The Department of Housing and Urban Development might issue, postelection, a "Notice of Funding Availability" (NOFA), which sets the criteria that the agency will apply in handing out a particular set of grants-say, for conversion of projects to subsidized housing for the "frail elderly." The agency generally can exercise considerable discretion in listing the criteria for its award of grants, including over which regions of the country will receive the greatest share of funding. ${ }^{440}$ Similarly, the Federal Emergency Management Agency (FEMA), as it did under the outgoing George H.W. Bush administration, might publish the list of communities nationwide in which property owners are eligible to purchase spe-

437 An agency may voluntarily devise procedures similar to those required by 5 U.S.C. \$ 553. See, e.g., Manning, supra note 114 , at $667 \&$ n.269 ("In many cases . . agencies have chosen to waive APA exemptions of notice-and-comment requirements and to subject themselves voluntarily to the procedures of notice-and-comment rulemaking."). An agency also may voluntarily agree to be bound by policy statements that are not otherwise binding upon the agency by operation of law. See, e.g., supra note 70 (quoting HCFA statements).

438 See text accompanying notes 352-54 (discussing argument that general public will become involved in policy dialogue only under limited circumstances).

439 See supra note 365 .

${ }^{440}$ E.g., Fiscal Year 2000 Notice of Funding Availability for the Assisted Living Conversion Program (ALCP) for Section 202 Projects, 65 Fed. Reg. 14,694 (Mar. 17, 2000). After the 2000 presidential election, HUD issued four Notices of Funding Availability (NOFAs) as well as several announcements of grant awards prior to the arrival of President George W. Bush. 
cial flood insurance. ${ }^{441}$ Further, an outgoing administration might award several-thousand-dollar bonuses to employees. ${ }^{442}$

These types of actions are publicly announced, but the grant or benefit award criteria and the ultimate grant decisions generally do not require public participation or a response to comments, as is required for notice-and-comment rulemaking. Moreover, they are often one-time events in the following sense: One NOFA or FEMA list is unlikely to set the criteria for all future similar awards of grants. Thus, in addition to escaping the threat of political discipline that would have been imposed by an upcoming election, providing little or no opportunity for public participation, and not being subjected to procedural requirements such as those imposed by the APA, these actions also are likely to be of lower visibility. Although grant recipients may apply repeatedly for additional funds, a particular NOFA with particular terms is likely to be a one-time event in a stream of different grant award decisions. Compared with entities affected by a rule, there may be relatively few repeat players among the grant applicants and others benefited by the grant program, relatively few incidences of significant costs, and consequently comparatively few entities or individuals with an incentive to challenge the agency's actions by appealing to the White House, Congress, the media, or other monitors of agency action. ${ }^{443}$

These types of policy actions thus are unlikely to generate the salutary effects discussed above. Because of their narrow effect, both temporally and in terms of individuals affected, they are less likely to engender a public dialogue that subsequently informs agency policy. Further, as one-time events, they are unlikely to serve the function of developing meaningful administrative limiting standards.

For example, while one HUD NOFA will limit the agency's distribution of funds in the short term, it is unlikely to assist the public in learning what criteria HUD will apply in its next NOFA, or in holding HUD to a particular decision standard for its development of NOFAs. Similarly, a FEMA listing of communities that are eligible for special subsidized flood insurance is unlikely to be accompanied by procedural safeguards and is less likely than other policy decisions to engender

441 See List of Communities Eligible for the Sale of Flood Insurance, 58 Fed. Reg. 4082 (Jan. 19, 1993) (to be codified at 44 C.F.R. pt. 64).

442 See, e.g., Al Kamen, Sunset for 'Midnight Bonuses,' Wash. Post, Dec. 13, 1993, at A19 (noting that Office of Personnel Management determined that bonuses awarded by outgoing Bush administration were not justified).

${ }^{443}$ For an analogous analysis suggesting that procurement contracting may present a greater risk of agency collusion with regulated counterparts than regulation, see Laffont \& Tirole, supra note 226, at 9 (noting, inter alia, that procurement contracting has no natural "watchdogs" except taxpayers, who are "poorly organized"). 
any significant public dialogue. The lack of procedural safeguards and probable lack of monitoring of these actions may also mean that they present a greater risk of abuse.

Agency actions such as decisions to file or settle litigation might be viewed similarly. While these decisions often embody the policy preferences of the outgoing administration, the decisionmaking process is not as transparent or disciplined as that in a notice-and-comment rulemaking process. A litigation filing must, of course, survive Federal Rule of Civil Procedure 11, and a government litigation settlement may be subject to independent judicial review. ${ }^{444}$ However, as with the issuance of grants, these decisions are limited in time and scope. There is no electoral discipline, little procedural discipline, and only a small chance that the agency will publicly announce criteria that will bind its discretion in the future. Again, the comparative lack of public engagement and procedural discipline, coupled with the lack of electoral discipline, means that these actions also could present a greater risk of abuse. ${ }^{445}$

\section{IV}

\section{Some Concluding Observations on Burrowing}

\section{A. Evaluating Policy and Personnel Burrowing}

Not all postelection agency actions present questions of legitimacy. The hard case is when an agency decides a personnel or policy question with the knowledge that the decision is likely to contradict the President-elect's policy preferences. I have argued, though, that while such agency burrowing is electorally undisciplined and could burden the new President's agenda-setting, budget, and political capital, it should not be hastily dismissed as illegitimate.

Despite burrowing's effects on agency responsiveness to the new President, the outgoing administration's desire to make policy decisions and make them in a lasting way can sometimes prompt agencies

444 See, e.g., United States v. Cordova Chem. Co. of Mich., 2000 WL 1238926 (W.D. Mich. Aug. 24, 2000) (reviewing consent decree as "fair, reasonable, and in the public interest").

445 For example, environmental group challenges to a State of Michigan settlement with Dow Chemical just before the arrival of newly elected Governor Jennifer Granholm could be read as alleging that the Department of Environmental Quality has been "captured." See supra note 193 (summarizing proposed settlement).

Monitoring by agency employees can deter inappropriate activity of this type. As discussed above, outgoing appointees functioning under the gaze of civil servants may be careful to avoid even an appearance of impropriety toward the end of a presidential administration. In the Department of the Interior, for example, civil servants may have tried to obstruct what they believed to be an inappropriate recognition of an Indian tribe. See supra text accompanying note 245 . 
to utilize policymaking forms that are both more disciplined and more binding upon the agency. Against the reduction in political responsiveness via the electoral process then, we should weigh a potential reduction in the risk of arbitrary and abusive agency action. Moreover, the public debate potentially engendered by an outgoing administration's burrowing suggests that a dialogue over agency policy that directly engages the public can significantly supplement or sometimes even outdo the presidential election process as a means of communicating public values to the agencies.

Not all postelection actions, however, contribute either to administrative agency accountability or democratic responsiveness. The important factors appear to be the form in which the action is rendered and its breadth and potential prospective application. To briefly summarize the discussion in Part III, policy burrowing may make positive contributions if it possesses some or all of the following characteristics:

(1) use of APA rulemaking or similar procedures with

(a) opportunity for public participation;

(b) explanation by agency of basis and purpose of policy; and

(c) opportunity for judicial review of policy;

(2) development of "self-limiting" principles that will legally constrain future exercises of agency authority; and

(3) prospective and broad application to a significant number of future transactions.

Correspondingly, we should be more skeptical about late-term actions, such as litigation settlements, the setting of grant-competition terms, or grant-distribution decisions, that involve significant discretion, are essentially one-time events, are otherwise narrowly focused, or lack procedural discipline. Such actions are less likely to contribute to democratic responsiveness or agency accountability. In addition, because of their narrow focus, these actions may engage fewer groups, generating less public dialogue. Where there is little public dialogue, the extent to which late-term actions benefit the public will depend in large part on the motivations and talents of the individuals making the decisions. Because their effects are so dependent on what is essentially individual goodwill, these actions seem to compound the risk of arbitrary or self-serving action presented by the lack of electoral discipline. ${ }^{446}$

While detailed suggestions for policy reform generally are beyond the scope of this Article, one possibility might be requiring agencies to

446 Of course, despite these risks, the postelection time period also may represent an opportunity to make these sorts of decisions free from excessive political pressure and according to the decisionmaker's best assessment of the public interest. 
collect and publicly report this latter set of actions, as the hiring of political appointees in civil service positions currently is reported to the Office of Personnel Management. ${ }^{447}$ Such reporting would help facilitate public and congressional oversight and deter arbitrary or abusive actions.

Personnel burrowing, too, has potentially positive consequences, including contributing to political diversity within the civil service ranks. This may both help assure a more balanced and thorough internal agency policy debate and increase monitoring of agency activity, in turn increasing agency accountability. Further, given the amount of turnover often occasioned by a presidential transition, late term hiring and promotion may be critical to an agency's readiness to function in the new administration.

As with some forms of policy burrowing, however, the ultimate effect of personnel burrowing may depend in large part on individual motivations, both of outgoing agency political appointees and of those they hire and promote. Consequently, the risks of personnel burrowing may be substantial. The ideal case is an outgoing administration's hiring or promotion of a talented individual who is committed to the institution, whose personal political views are different from those of the new President, and who is involved in a vital ongoing agency policy dialogue, but who is also willing and able, once an agency decision is made, to thoroughly implement it. On the other hand, a departing political appointee potentially could hire, fire, or reorganize an office in a way that undermines programmatic goals or else make personnel decisions that simply reward loyalists. Further, once hired, a civil servant could passively or actively subvert the goals of the new administration, actions sometimes hard to detect. (Of course, a civil servant not hired during the transition also could behave this way.)

Because of the comparative lack of procedural constraints and public information on hiring, identifying the sort of hiring or personnel reorganization that might present special risks is difficult. As Hugh Heclo's work has shown, political considerations can play a role in civil service hiring and promotion even with merit-based hiring criteria. ${ }^{448}$ Further, with the exception of the hiring of political appointees into civil service positions, which is publicly monitored and

447 See, e.g., Recruitment and Selection for Initial SES Career Appointment Be Achieved from the Brightest and Most Diverse Pool Possible, 5 C.F.R. $\$ 317.501$ (2002); LaChance Memorandum, supra note 209 ("OPM will review all proposed actions to place in the competitive service: (1) current and former (within the past five years) [political appointees]; and (2) current and former (within the past five years) noncareer [Senior Executive Service] employees.").

448 See supra text accompanying note 232 . 
reported, late-term hiring is monitored only on an ad hoc basis. Again, required reporting of these personnel decisions-or perhaps a greater burden of justification before certain promotion or reorganization decisions can be made-might help open up these decisions to greater public view.

\section{B. Revising the Focus on Presidential Control}

Focusing for the moment on the positive side of burrowing, the contributions that policy and personnel burrowing can make to both agency democratic responsiveness and accountability suggest that we should reassess President-focused theories of the administrative state.

From the standpoint of ensuring the democratic responsiveness of agencies, the President's desire to win reelection serves, of course, as a major incentive for her to consider public preferences and to urge the agencies to do the same. However, the presidential control model relies too heavily on the election as the measure of the President's ability to detect public preferences and transmit them to agencies. That theory, as is also true of the civic republican ${ }^{449}$ and pluralist ${ }^{450}$ theories, fails to consider fully the prospect that public preferences may be unformed or poorly defined-or that even if they are well-formed, the presidential election is a highly imperfect conduit for those preferences.

The policy burrowing examples described in this Article suggest the need to recognize more explicitly the President's limitations as a courier of public preferences and to thoroughly consider links between the public and agencies, beyond the conventional path of voters to President to agency. Some agency burrowing has generated dialogue that has raised the visibility of administrative policy choices and has engaged the public more directly in policy debates; other actions may help assure that internal agency dialogues will be more vital and balanced. These processes can contribute to agency consideration of an appropriate array of public preferences and values and to an enhanced public discussion resulting in public views more refined and crystallized than those transmitted through a presidential election.

449 As discussed above, civic republican theories recognize that preferences may evolve as the agency-or the electorate-considers the appropriate response to a policy problem. See supra text accompanying notes 87-89. However, civic republican theories of the administrative process still identify the President as a "democratic check" on the civic republican agency process. See supra text accompanying notes 118-26.

450 In a pluralist view, agencies simply need to detect and aggregate public preferences. See, e.g., Pildes \& Anderson, supra note 327, at 2144 ("Democracy aggregates preferences that individuals have already put into a rational order; its institutions are not needed to enable individuals to rationally order their preferences in the first place."). 
Thus, to the extent we seek democratic responsiveness in agencies, we might profit by more actively considering opportunities to directly engage the general public in specific, contemporaneous administrative policy discussions. The public participation opportunities of notice-and-comment rulemaking, of course, do contribute to the democratic responsiveness of administrative rules. ${ }^{451}$ However, agencies often bypass that process, and as noted above, even when utilized, that process may engage only narrow segments of the public. ${ }^{452}$ Beyond notice-and-comment processes, agencies might consider (well-publicized) public meetings to present developed policy alternatives, providing plain-language information on policy problems in "citizen pamphlets," or convening citizen advisory groups. ${ }^{453}$

Theories that focus heavily on the President face even greater problems when it comes to ensuring agency accountability. Voters wishing to hold agencies accountable for poor performance can, of course, invoke their power to refuse to reelect the President. In the meantime, however, presidential control seems insufficient to ensure accountability. Further, it may work at cross-purposes with the goals of ensuring that agencies must account for and justify their actions and exercise discretion within definable bounds. Because a President likely will desire agency responsiveness, to better respond to changing policy preferences, she and her agency heads will wish to preserve agency flexibility rather than publicly developing rules that will legally constrain agency discretion. That incentive can have significant opportunity costs for the discipline of agency decisions, for the extent to which agency action is governed by the rule of law, and for agency accountability to other institutions, such as the courts and citizens at large.

Moreover, presidential supervision itself is not likely to counteract fully this potential cost. Despite recent innovations in presidential supervision of agencies, the President and her appointees are quite unlikely to possess the resources to effectively monitor agency performance at all levels. And to the extent there is "capture" of the President and her political appointees that would warrant monitoring, they will have little incentive to disclose relevant information to the public.

Certain forms of agency burrowing, though initiated by a President who has just lost an election, suggest that we should look beyond

451 Id. at 2122; Stewart, supra note 75 , at 1712.

452 See supra text accompanying note 351 .

453 See Pildes \& Sunstein, supra note 257 , at 105 ("[G]overnment [should] provide enough information so that people could make knowledgeable judgments."). Citizen pamphlets accompanying voter referenda might serve as one example. 
the White House for additional sources of agency accountability. As the examples in this Article suggest, an outgoing President's desire for durable policy decisions may spur agencies to develop administrative limiting rules. These rules generally require a more open and disciplined rulemaking process than informal methods of directing agency policy. They also act to confine agency discretion, which in turn makes agency decisions more predictable, more subject to a rule of law, and subject to more effective oversight by the courts, Congress, the White House, and the public at large. And even with its risks, personnel burrowing suggests the value of relying on more monitorsand more decentralized monitors-as a way of exposing potential agency nonfeasance and malfeasance.

We therefore might wish to consider structural reforms that would encourage agencies to more often publicly explain or publicly constrain their use of statutory discretion. For example, Congress might enact legislation to reduce the costs of notice-and-comment rulemaking or to require agencies to prepare administrative limiting rules. Further, we might wish to take steps to assure that agency activity is subject to a more numerous, diverse, and well-informed group of monitors. That might help open an agency to public view over the long term and contribute to monitoring by Congress, the courts, the electorate, and the media.

So does this mean that agency entrenchment activities should be permitted willy-nilly - or perhaps that an outgoing President should select all agency policymakers? Certainly not. Agency entrenchment activities take place without the safeguard of an upcoming election, can impose real political and efficiency costs upon a new President, and could represent attempts to undermine her ability to carry out her constitutional responsibilities. For some forms of burrowing, these may be costs that, on balance, we do not wish to tolerate. Moreover, some policy and personnel entrenchment activities not only lack the safeguard of political accountability supplied by an upcoming election, but do not take place in the public eye and may lack key procedural safeguards. We might wish to publicize or monitor such activities more closely to assure that they are not used as a vehicle to serve a narrow set of interests or the agency decisionmaker's personal interests.

However, despite the costs of burrowing for the incoming President, a fuller assessment of the effects of policy entrenchment through rulemaking and personnel entrenchment does suggest that we sometimes should look upon these actions not as unsavory power grabs, but as the departing President's attempt either to evoke public attention regarding an issue that escaped discussion during the national elec- 
tion, to confine agency discretion, or to ensure the continued representation of a key viewpoint in agency deliberations.

And more broadly, the experience of agency burrowing suggests that theories of the administrative state and concrete proposals for reform should focus more directly on functional considerations. We should give greater attention to the need for meaningful public and internal agency dialogues on policy issues, effective monitoring, procedural discipline, and public and binding declarations of decision criteria as important components of agency accountability and political legitimacy, even if those come with some cost to presidential control. 